\title{
The oldest pottery in hunter-gatherer communities and models of Neolithisation of Eastern Europe
}

\author{
Andrey Mazurkevich, Ekaterina Dolbunova \\ The State Hermitage Museum, Department of Archaeology of Eastern Europe and Siberia, St. Petersburg, RU \\ a-mazurkevich@mail.ru \\ katjer@mail.ru
}

\begin{abstract}
The characteristics of the oldest pottery in Eastern Europe, located in three main regions, the Lower Don and Lower and Middle Volga, and a description of different Early Neolithic types of pottery production are described in this article. We present ideas on how and when the oldest pottery traditions were distributed through Eastern Europe according to radiocarbon dates. Also, models of the Neolithisation of Eastern Europe are suggested based on archaeological evidence and absolute chronology.
\end{abstract}

IZVLEČEK - V članku predstavljamo značilnosti najstarejšega lončarstva in zgodnje neolitske keramične tipe v treh vzhodno evropskih regijah: Spodnjem Donu, Srednji in Spodnji Volgi. S pomočjo radiokarbonskih datumov pojasnjujemo, kako in kdaj so se najstarejše lončarske tradicije širile prek Vzhodne Evrope. Predlagamo model neolitizacije Vzhodne Evrope, ki temelji na arheoloških podatkih in absolutni kronologiji.

KEY WORDS - Early Neolithic; Neolithisation; pottery technology; radiocarbon chronology

\section{Introduction}

New discoveries about Early Neolithic cultures and sites in Europe, their radiocarbon dates, and information about climatic conditions (Weninger et al. 2006; Berger, Guilaine 2009) led to a new wave of discussion about the components of the 'Neolithic package' (Özdoğan 2011), and ways, forms and models of the distribution of Neolithic innovations (Dolukhanov 2000; Demoule 2007; Cauwe et al. 2007; Davison et al. 2009; Fort 2009; Feugier et al. 2009; Mazurkevich et al. 2006; Budja 2013). In addition to a productive economy, pottery and polished tools, it was proposed that prestigious/cultic objects, architecture, settlement organisation, and a new way of life should also be included in the Neolithic package (Özdoğan 2011.419). In order to outline the importance of the changes occurring during this time, besides the term 'Neolithic revolution', definitions of other revolutions were proposed: the 'secondary product revolution', introduced by Andrew Sherratt (use of domesticated animals for the purpose of pro- ducing 'secondary products', such as milk, wool, and draught power at the end of Neolithic/Bronze Age) (Greenfield 2010), and the 'ceramic revolution' (describes how Neolithic innovation was distributed in Eastern Europe) (Mazurkevich et al. 2006.20). However, the 'Neolithic revolution' that occurred in technological and ideological spheres is not now regarded as a rapid process which had an equal influence on all Mesolithic groups that came into contact with Neolithic cultures (Barnard 2007.17).

It is supposed that we can trace the integration and coexistence of Mesolithic people with new Neolithic traditions/incomers, rather than an abrupt change in Mesolithic traditions during the earliest stage of Neolithic cultural development in different regions (Guilane, Manen 2007; Bentley 2007; Hartz et al. 2007). Pottery is the only archaeologically visible marker of changes in the cultures of Eastern Europe, unlike in other parts of Europe, where not only pot- 
tery but also other components of the Neolithic package were distributed. This is why Eastern European cultures were excluded from the general Neolithic context in Europe. Various definitions have been proposed to describe the cultures of hunter-gatherers acquainted with ceramic manufacture, such as 'Boreal Neolithic', 'Sub-Neolithic', 'Initial Neolithic' (Davison et al. 2007.140; Gronenborn 2010; Dolukhanov, Shukurov 2009.36; Tallavaara et al. 2010. 253; Cohen 2014). However, it is suggested that the level of social development and complicated social networks that existed should be taken into account in order to estimate the crucial changes that occurred in this transitional period (Oshibkina 1996). Radiocarbon dates have recently shown the old age of the first pottery in eastern Europe, attributing it to the first half of the $7^{\text {th }}$ millennium calBC ${ }^{1}\left(\mathrm{Vy}^{-}\right.$ bornov et al. 2008; 2012; Mazurkevich et al. 2013) (Map 1, Fig. 7). This material is some of the earliest evidence of pottery among communities of huntergatherers in Eastern Europe.

The early appearance of pottery that is not related to the distribution of productive economies can also be traced in Southern China at the 20-16th millennium BP, in the Far East and Japan at 17-15 th millennium BP, in Southern Siberia at the end of the 14th millennium BP (Budja 2010.118; Cohen 2014. 62 ), and in the $10-8^{\text {th }}$ millennium BP in Southern Africa (Close 1995). Pottery appeared in these regions independently and has been discovered over a vast area. After pottery making appeared in Southern Africa, it spread over a distance of $3000 \mathrm{~km}$ (Close 1995.32). Recently, a hypothesis suggesting the eastern origin of East European pottery has been discussed (Gibbs, Jordan 2013.16). However, there are no intermediate sites with pottery similar and synchronous with the first pottery in the Far East over a huge area from the Far East to the Southern Urals, a distance of over $9000 \mathrm{~km}$, which could prove this theory; nor might any similarities be found between the pottery of Eastern Europe and early Eastern or Western Siberian ceramic assemblages.

We suggest that the oldest pottery in Eastern Europe had special characteristics which could make it part of a near-eastern Neolithic package that arrived here in different ways and from different places, whereas the further development and appearance of other cultural traditions in Eastern Europe can be connected with the regional development and interaction of hunter-gatherer communities (Map 2).
Different groups can be distinguished in the pottery assemblages of Eastern Europe ascribed to the Early Neolithic that differ in their technological, morphological and decorative features. Some are very similar, although separated by hundreds of kilometres. At the same time, the deposit of Early Neolithic pottery together in one stratigraphic layer suggests the simultaneity of these events, which can in reality be separated by long periods. This is why a technological and typological analysis of pottery, together with radiocarbon dates and stratigraphy, is necessary in order to distinguish the oldest groups within pottery assemblages.

An overview of the oldest pottery traditions of Eastern Europe is presented in this article, along with a discussion of their chronological position, distribution and origin.

\section{Absolute chronology of Early Neolithic pottery in Eastern Europe}

The analysis of the radiocarbon dates attributed to the Early Neolithic pottery of Eastern Europe (according to Vybornov 2008; Vybornov et al. 2008; 2012; 2013; Ivanischeva 2009; Hartz et al. 2012; Smol'yaninov, Surkov 2014; Tovkailo 2010; Gaskevich 2010; Karmanov 2008; Zaiceva et al. 2014) makes it possible to divide dates into groups (Figs. 4-6). These groups relate to different types of the earliest pottery, represented by undecorated vessels, pottery decorated with impressions (triangular and/or dots) and with incised lines, as well as vessels of later stages with different technological and typological characteristics.

The dates of these types of pottery are believed to be distributed non-uniformly in the time span, but concentrated in certain periods. This might be explained by the increase in the number of sites, materials and, perhaps, population during these periods. These dates make it possible to synchronise different events reflected in the appearance of various types of pottery, and also show that bearers of different traditions could coexist during the same periods in the same area. Several explanations may be proposed: the appearance of various types of pottery at the same sites could have been separated by short periods which cannot be detected from radiocarbon dating, and also the coexistence of societies with different pottery or 'Mesolithic' and 'ceramic' communities might be supposed.

1 calBC - calibrated dates according to OxCal 3.10 (Bronk Ramsey 2005). 
The oldest pottery assemblages from Eastern Europe date to the first quarter of the $7^{\text {th }}$ millennium calBC. One of the oldest complexes with pottery can be found at Rakushechny Yar in the Lower Don ba$\sin ($ Map 1).
The next period with a concentration of dates is attributed to the beginning of the second quarter of the $7^{\text {th }}$ millennium calBC, connected to the Elshanskaya culture pottery in the Middle Volga region. According to the radiocarbon chronology, the Elshan-

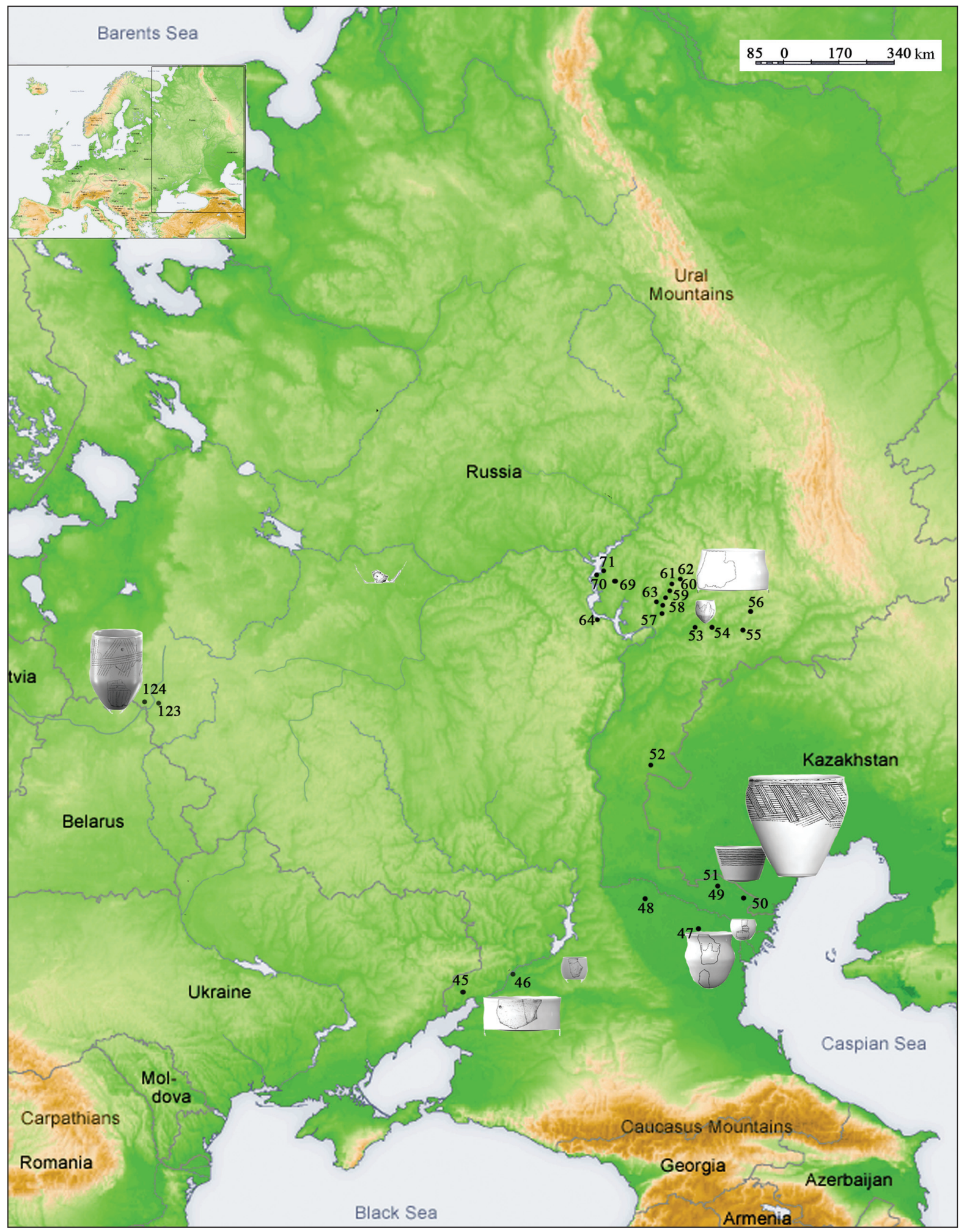

Map 1. Distribution of sites with the oldest pottery during the first half of the $7^{\text {th }}$ millennium calBC in Eastern Europe (according to radiocarbon dates). 
skaya culture existed here for a long period (Vybornov 2008).

The concentration of dates around the middle-second half of the $7^{\text {th }}$ millennium calBC is connected with pottery decorated with triangular impressions and dots from the Lower Volga and the Caspian basin. It might date to an even older time, evidenced by the appearance of this type of vessel in the first ceramic assemblages of Elshanskaya culture (Viska-

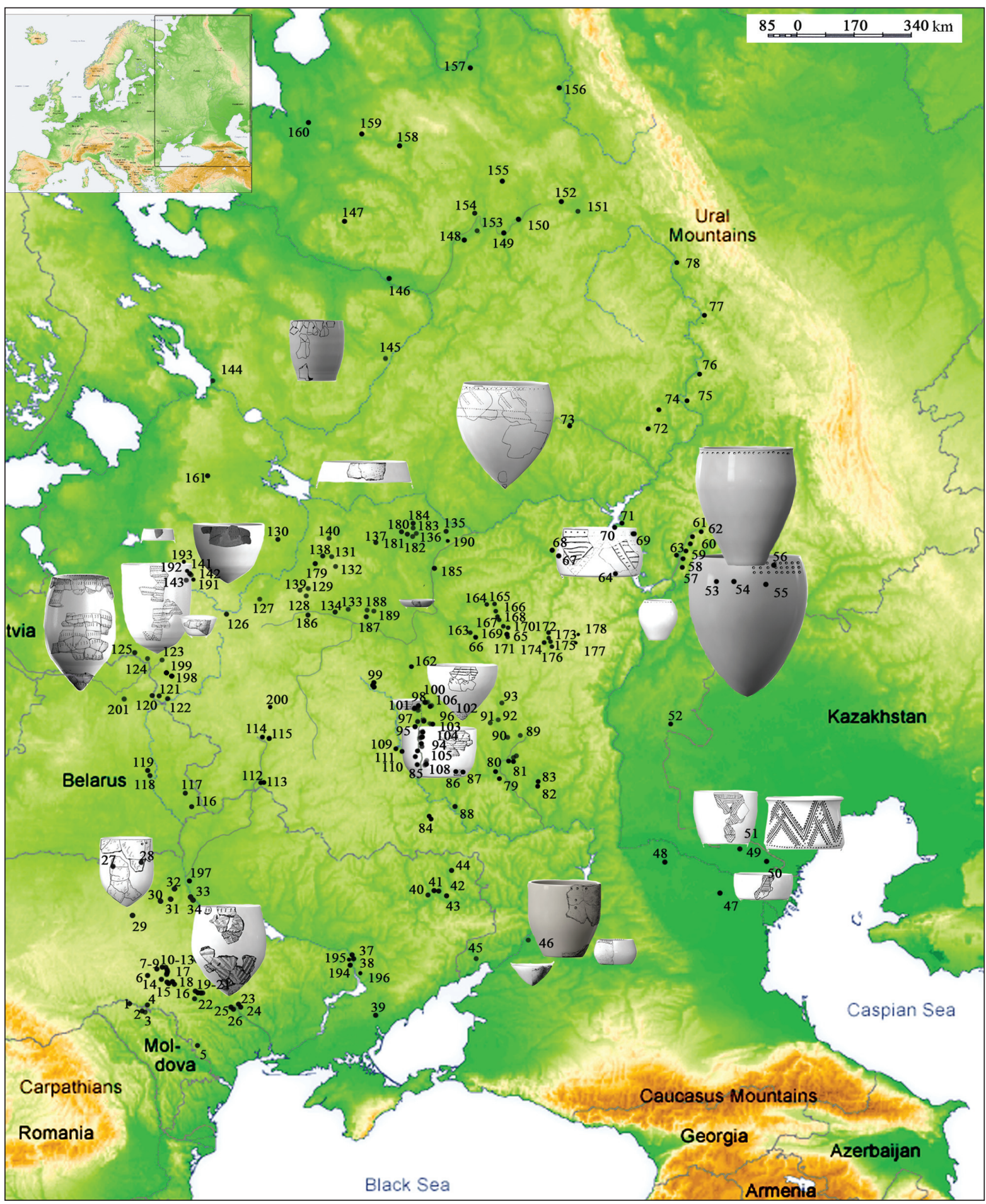

Map 2. Sites with Early Neolithic pottery in Eastern Europe dated to the middle of the $7^{\text {th }} 6^{\text {th }}$ millennium calBC (site positions according to Gaskevich 2010; Vybornov 2008; Krainov 1996; Smol'yaninov 2009; Surkov 2007; Smirnov 1991; Sinyuk 1986; Karmanov 2008; Tyurina 1970; Stavickii, Hrekov 2003; Lychagina, Cygvinceva 2013; Urban 1996; Gurina 1997; Telegin 1996; Cvetkova 2011; Cetlin 2008; Kotova 2002). For the list of Neolithic sites 1-195 see Appendix. 
lin 2014). The distribution to the north of populations in the northern Caspian and Lower Volga region can be dated to the second half of the $7^{\text {th }}$ millennium calBC, which led to the formation of a new culture in the Middle Volga basin (Andreev 2014. 14).

Radiocarbon dates between $8000-7500$ BP yield a large spread of possible calendar age ranges because of a plateau in the calibration curve (Alekseev et al. 2005.42). This makes it difficult to obtain narrow calibrated spans for different ceramic traditions and to date more precisely their distribution in various areas (Fig. 4a).

It is interesting that the increase in the quantity of radiocarbon dates at sites with decorated pottery in the Caspian region happened at the end of the $7^{\text {th }}$ millennium calBC and beginning of the $6^{\text {th }}$ millennium calBC, but this was absent at sites with undecorated pottery. Elshanskaya culture stage II appears at the end of the first/second quarter of the $6^{\text {th }}$ millennium calBC. This stage also includes ceramic complexes from other areas dated to the second half of the $6^{\text {th }}$ millennium calBC. Pottery assemblages of sites located in the north Caspian Region, such as Jangar (layer 2), Kachkarstau, Tenteksor I, date to the middle of the $6^{\text {th }}$ millennium calBC. Another concentration of dates for pottery decorated with triangular impressions can be traced in the second half of the same millennium.

The increasing quantity of dates from the forest and forest-steppe zone achieved recently fall in the interval of the middle/second half of the $7^{\text {th }}$ millennium calBC, which can hardly be explained solely by an age offset due to the reservoir effect. According to recent research, the hard-water effect, which could have influenced these dates, could be absent or minimal in some regions (Kulkova et al. 2014). Moreover, the dating of modern materials does not allow us to determine the real age offset which must be taken into account in date calculation (Kulkova et al. 2014; Philippsen 2014). Also, the analysis of early Neolithic vessels from Eastern Europe reveals that some were used to cook non-aquatic products, which excludes the possibility of any reservoir effect (Meadows 2014).

It seems that these dates reflect some cultural processes occurring since the second half of the $7^{\text {th }}$ and middle of the $6^{\text {th }}$ millennium calBC. This is a period when local, regional traditions in the Upper Volga, Middle and Upper Don, Dnepr-Dvina regions and other territories formed and developed and spread to neighbouring areas (Map 2, Fig. 5).

Besides the oldest dates from the Lower Don, Lower Volga and Middle Volga regions, there are also dates falling in the interval of the first half/middle of the $7^{\text {th }}$ millennium calBC obtained from organic crust on vessels or synchronous materials from northern territories, which shows the very old age of this pottery, almost synchronous with the appearance of the oldest pottery in the southern areas (Mazurkevich et al. 2013).

It is important to understand how this almost simultaneous appearance of ancient pottery occurred in various regions of Eastern Europe that are separated by hundreds and even up to 2000 kilometres; can we trace these processes in archaeological material, not only in radiocarbon dates, and what cultural model could best explain this type of evidence?

\section{Description of different regional cultures with the most ancient ceramic traditions}

\section{Lower Don Region: the ceramic assemblage from the Rakushechny Yar site}

Rakushechny Yar is located at the north-western end of the modern island of Porechny on the Don River (Fig. 1). An area of approx. $1000 \mathrm{~m}^{2}$ was excavated by an expedition from Leningrad State University under the direction of Tatyana D. Belanovskaya in 1961-1966, 1968, 1971, 1976-1977, 1979 (Belanovskaya 1995.9-12); new excavations of the oldest layers were conducted by Pavel Dolukhanov, and later by Andrey Tsybriy and Andrey Mazurkevich (Tsybriy et al. 2014). The cultural layer at Rakushechny Yar consists of several isolated outcrops of different sizes, often at a distance from each other, where excavations II - V were made. Excavation I was in the central part of the site. Belanovskaya divided the site into six horizons, with several layers forming the sixth horizon (Fig. 2); all were identified as cultural layers separated by sterile interlayers. Layers 9-23 were attributed to the Early Neolithic.

The first researchers to investigate the site outlined its unique character and traced analogues with Near Eastern materials (Belanovskaya, Timofeev 2003). However, only a small part of the excavated lower layers, uncovered in 1965 when the level of the Don was very low, yielded a very restricted complex of finds, which appeared to be very small in the lowest layers (23-21). This should be considered when in- 
vestigating this Early Neolithic complex, which reveals a small fragment of the ancient history of this region.

In this research, ceramic materials from layers 23-11 from excavation I (housed in the Department of Archaeology of Eastern Europe and Siberia of the State Hermitage Museum) were studied. The assemblage consists of 2421 wall and rim fragments of vessels and 272 fragments of bottoms and low vessel parts

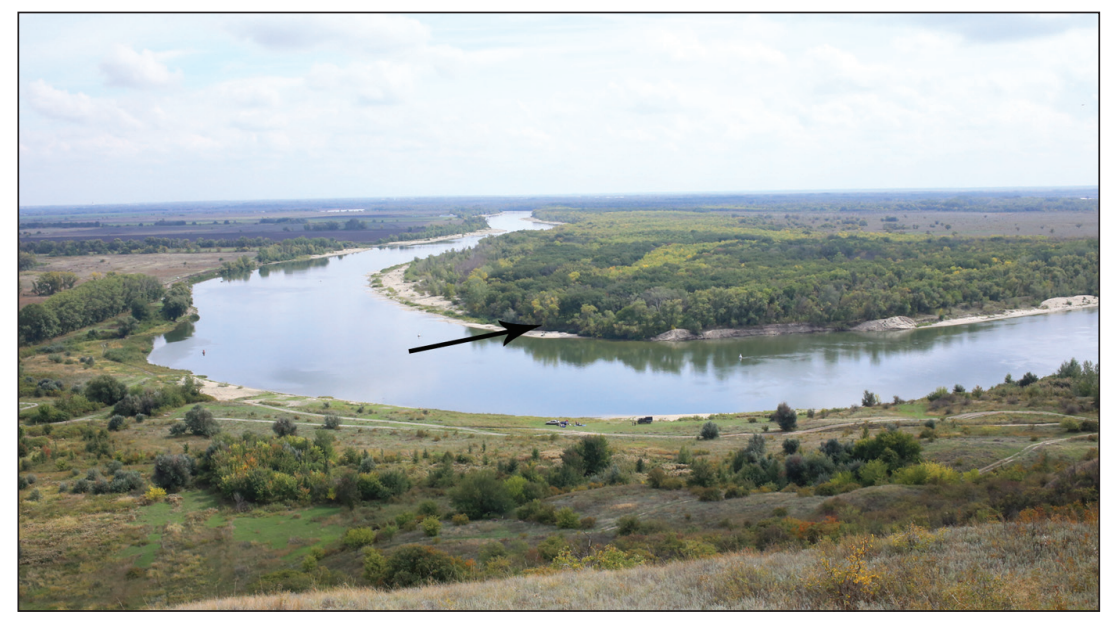

Fig. 1. View of the Rakushechny Yar site. attributed to approx. 490-500 vessels.

The petrographic studies by Marianna Kulkova determined the mineral composition of the paste, identified tempering materials, and determined their quantity (Mazurkevich et al. 2013). Several raw materials were distinguished which could be located at different hypsometrical levels and which have different origins. The use of these different types of clay and silty raw materials probably depended on variations in the level of the river. The characteristics of the raw materials of these vessels point to an origin near the site, which allows us to suppose that the pottery was made locally. Thus, Neolithic potters used various raw materials to produce pottery, depending mostly on its accessibility at different times.

The following pastes used in pottery making were identified by visual analysis:

- Plastic clay with natural inclusions of shells, with or without a small amount of temper. The clay was well kneaded at the pre-treatment stage, which is typical of pottery from the lowest layers. Also, there are vessels made from the same type of paste, which was poorly kneaded, and with a great quantity of natural organic matter. This type of vessel increases in quantity in the upper layers.

- Clay mixed with organic temper was also found at the site.

- Also, there is a type of a paste with grog or crushed pottery temper added to the paste, which was confirmed by the petrographic analysis (Mazurkevich et al. 2013).

That the technology of pottery making was stable is proved by the existence of definite chaînes opératoires in all layers. Several types of coil modelling were identified: N, U (Tab. 1.1), and S-type of coils junction (Tab 2.4), and the slab technique (Tab. 3.2 ). The thickness of vessel walls is $0.6 \mathrm{~cm}, 0.7-$ $0.9 \mathrm{~cm}$, and $1.2 \mathrm{~cm}$. Coils were stretched in most cases when N-junctions of coils were applied (Tab. 3.3). $\mathrm{N}$-junctions of coils with stretching predominated in vessels from the lowest layers 23-11 (Tabs. 1.2, 2.3). Additional pieces of clay were often used (Tab. 3.1 , which is clearly seen in radiographic photographs of the fragments.

Vessels from layers 13-11 were made with long coils stretched vertically, and consisted of two to three layers (Tab. 1.3). In addition, the 'paddle and anvil' technique appeared in layers 13-11; the diameter of anvils might not have exceeded $3-4 \mathrm{~cm}$. Vessels made with the slab technique appeared here, as well as with blocks of coils which were attached with a U-shaped junction. These were made by long coils stretched vertically. This type of modelling could have been used for large vessels with diameters of about $40 \mathrm{~cm}$.

The forming of the rim was the same on all the vessels from layers 23-11. Rims have almost perfectly flat and symmetrical edges, which shows that a technique was used that allowed the vessel rims to appear almost uniform. Usually, the flat edge of the rim was formed either by a coil that was bent out or by the addition of a small coil to thicken the edge of the final coil. The rim was then pressed with fingers, which is evident from the traces of finger pressure, and treated with some tool with a flat edge. In several cases, we observed traces of pebble use.

The surface treatment included the redistribution of excess clay and levelling of the surface with a comblike tool and further smoothing and polishing. The vessel surfaces are eroded due to post-depositional 
conditions and further cleaning of finds. This is why some traces of surface treatment did not survive. The surface was usually smoothed; there are traces of smoothing made with 'wet hands', pebbles, and also traces of bone tools (see Martineau 2001.Figs. 17-18). Traces of a comb-like tool left in the process of roughening can often be observed on the inner surface, which was especially important while making vessels with thick walls to remove or redistribute surplus clay. Traces of working with comb tools are often smoothed. In rare cases, they can also be traced on the outer surface of the vessels that is well smoothed. Elaborate polishing is rarely observed and is usually present on surfaces of thin-walled vessels decorated with dots or undecorated. Smoothing and polishing was often made after decoration, which is proved by the indistinct form of the impressions. Fragments of thick walls (to $1.2 \mathrm{~cm}$ ) with traces left by a thin comb tool on both surfaces which were not smoothed later were found in layer 20 and the layers above. This type of technique corresponds with a new clay paste with organic temper. Traces left by comb tools are very rare on vessels from layers 15-11, which can be explained either by very careful smoothing of the surfaces of these vessels or because comb tools were no longer used. A new tool for surface smoothing, probably a wooden tool or a shell, was used in this period, leaving thin linear traces on the surface of vessels (see examples of traces in Glushkov 1996).

Vessel bases were made with slabs pressed together or from coils formed in a spiral from the centre of the base (Tab. 1.6.1). The vessel was then shaped by stretched coils. This is clearly seen due to the 'gro-

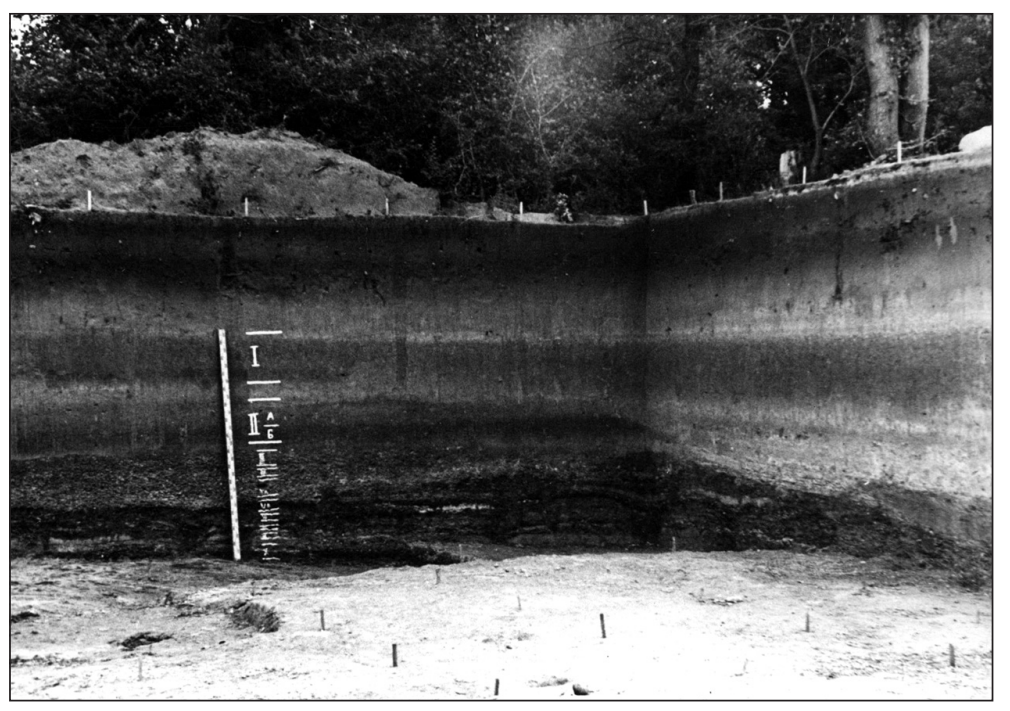

Fig. 2. Rakushechny Yar. View of excavation I (1964) and layers (after Belanovskaya 1964.Tab. 2). ove' along the perimeter of the flat base (Tab. 1.7a) which appeared as the result of finger pressure while attaching the first coil of the body to the base.

Some 13 vessel forms were identified in total (Pls. 1, 2) in layers 23-11 (Tabs. 4-10) (Mazurkevich, Dolbunova 2012). Vessel rims are predominantly flat and roundish, while pointed rims are rare.

In most cases, only the upper parts of vessels can be reconstructed, but due to the parts near the base and the profile features, it can be supposed that most had flat bases. Flat bases have varying diameters $(4-6 \mathrm{~cm}, 7-9 \mathrm{~cm}, 10-11 \mathrm{~cm}, 12 \mathrm{~cm}, 16 \mathrm{~cm})$. Bases with a diameter of $7-9 \mathrm{~cm}$ are the most widespread. The analysis of divergence angles of the low parts of the vessels allowed us to trace several features (Pl. 3 ). Divergence angles of $65-70^{\circ}$ were typical of bases in the lowest layers; in the upper layers, bases of different types appeared (from $46^{\circ}$ to $80^{\circ}$ ). Four different divergence angles existed in layer $20\left(50^{\circ}, 60^{\circ}\right.$, $65^{\circ}$ and $70^{\circ}$ ). In layer 13 , bases had different angles (from $48^{\circ}$ to $78^{\circ}$ ). Some definite standardisation of the divergence angles of bases were found in layer $12\left(55^{\circ}, 65^{\circ}\right.$, rarely $70^{\circ}$ and $\left.75^{\circ}\right)$. The maximum standardisation is seen in layer 11. In this layer, bases were made with three main standards $\left(65^{\circ}, 70^{\circ}\right.$, $75^{\circ}$ ); bases with other angles were rare in this layer $\left(46-48^{\circ} ; 55-62^{\circ}\right)$. This strict standard may testify to the use of some forms for making the bases of vessels or the use of tools bevelled at a definite angle for pottery moulding.

Pointed bases from layers 13 and 11 can be found in the collection of the State Hermitage Museum (Tabs. 9.15, 10.11). Belanovskaya (1995. $104)$ noted the existence of a pointed base in layer 20, but the method of production and the forming suggest it is more probably a fragment of a flat base. Pointed bases have two standards of divergence angles $\left(90^{\circ}\right.$ and about $\left.110^{\circ}\right)$. Also, round bases probably existed in layers 21 , 20 , and 13-11.

We can observe from reconstructed vessels that the height/diameter ratio is 1 to 1.3. Vessel forms can be divided into four volume groups according to their diameter (which are $7-9 \mathrm{~cm}, 12-16 \mathrm{~cm}, 18-24 \mathrm{~cm}$ and $30-$ $40 \mathrm{~cm})$. Vessels have estimated volumes of 0.25-0.4, 1-2, 5-6 and 14.5- 
20 litres, correspondingly. A particular group consists of 'bowls' and 'plates' (forms 6 and 12) where the height/diameter ratio is 0.3 to 0.4 , and the volume is about 0.15 to 0.3 litres (form 12).

Most of this pottery is undecorated, and decorated vessels comprise only $9 \%$ of the assemblage; in individual layers this percentage is even lower (Mazurkevich, Dolbunova 2012.Tab. 1). Vessels covered with red and yellow ochre on the outer and/or inner surfaces are also present at the site. A layer of red ochre can clearly be seen on some of the vessels, but usually only small parts of ochre survived on the surfaces. Also, an Unio shell with a layer of ochre inside was found in layer 20. The analyses (microscopic, microchemical, X-ray fluorescence spectroscopy, infra-red spectroscopy) made in the State Hermitage Museum by L. Gavrilenko of these fragments in order to identify the material on the surface lead us to believe that more than $10 \%$ of the whole ceramic assemblage was covered with red and/or yellow ochre consisting of iron oxide (II, III) and iron hydroxides with traces of titanium and manganese compounds.
The pottery is decorated with different impressions and incisions: small and large triangular, roundish (in layer 20), rectangular and large denticulated impressions, double toothed, impressions of belemnite (in layer 14), large pinches (in layer 15), drop-like dots, vertical and horizontal incisions, and also impressions made by a comb-tool creating several motifs. The design techniques vary: pin action, 'rocking-chair', drawn, individual marks linked through a single continuous stepped back drawn movement. A variety of techniques is seen in pottery from the lowest layer, where material decorated with triangular and rectangular impressions was found, drawn traces of 'comb', lines and denticulated impressions made with the 'rocking-chair' technique (in layers 23-22).

The decoration is very simple, consisting of horizontal and parallel lines of impressions (e.g., Tab. 4.1-3) usually covering only the upper part of the vessel. Vessels decorated with a net of impressions left by a comb-tool were also found (Tab. 6.4). Pottery decorated with a figure made with triangular impressions was found in layers 20 and 19. Pottery

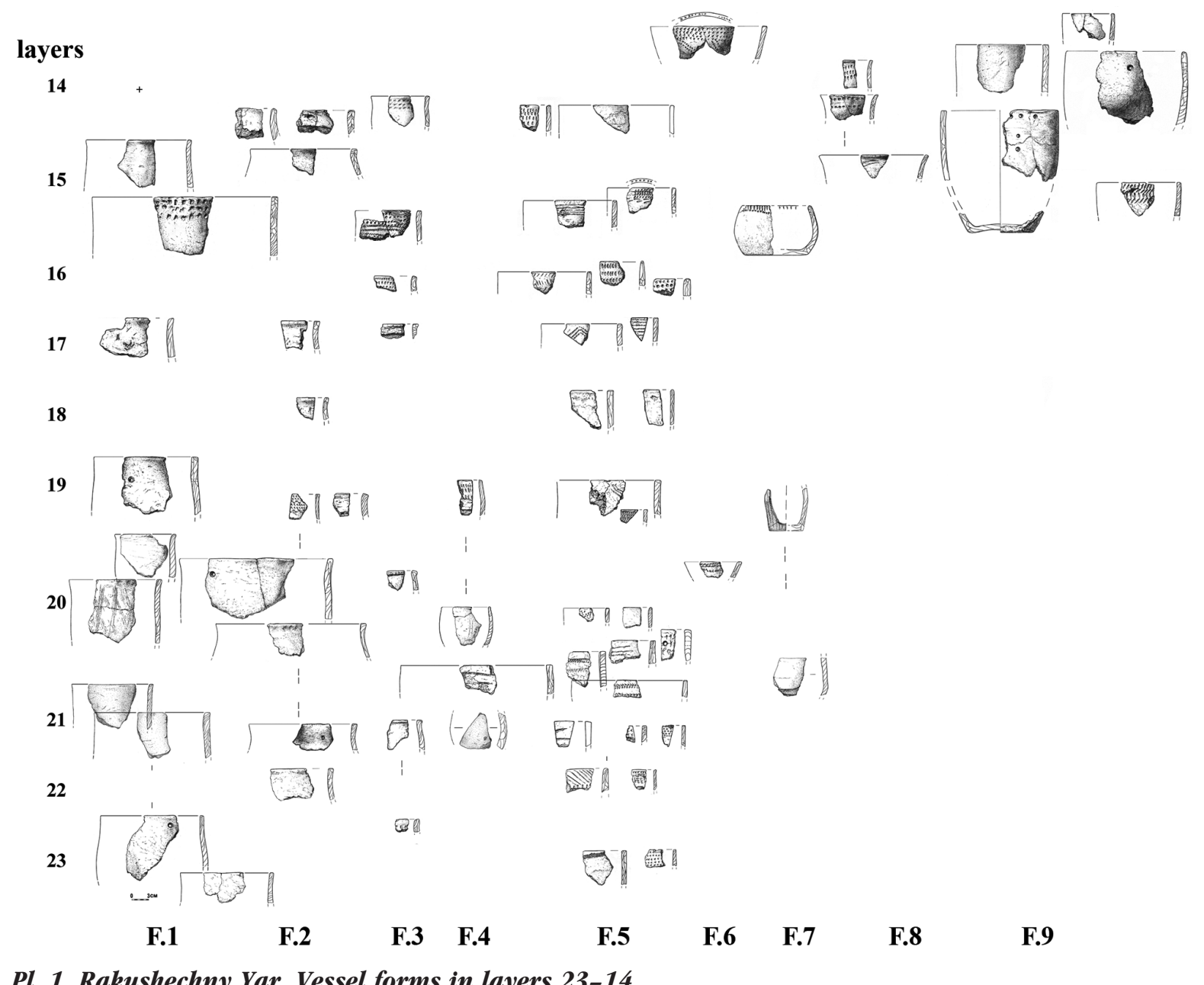


with geometrical motifs consisting of diagonal parallel lines appeared in layer 21 , and pottery with other diagonal compositions in layer 16 (Tab. 8.3). It was in this layer that not only new compositions appeared, but also new impressions for decorating vessels in this style (for example, Tab. 9.9,14).

Chronology, genesis and characteristics of Early Neolithic complexes at Rakushechny Yar The pottery assemblage from Rakushechny Yar consisted of flat-bottomed vessels of different forms, with standardised rims and bases of vessels, the existence of several chaînes opératoires, characteristic types of technology used to make definite forms of vessels, the rare use of decoration and traditions of surface treatment with red or yellow ochre.

The great variety of raw materials and clay pastes used for pottery shows the ability of potters to adapt to different types of materials which were available at different periods, which might be an indicator of developed skills and experience in pottery making (Mazurkevich et al. 2013). The ability to adapt different types of raw material and their use in the framework of different chaînes opératoires could be interpreted as a developed cultural tradition. This was not typical of pottery making in northern areas, such as the Dnepr-Dvina Region, where the process was rather conservative and where definite pottery recipes were used in various 'ceramic phases'. The range of similar technological operations typical of vessels of the lowest layers (e.g., surface smoothing and vessel treatment with a comb-like tool, modelling of symmetrical flat rims, predominance of the coil technique with N-junction, use of well-kneaded clay and additional pieces of clay for modelling, typical vessel forms) allow us to characterise this pottery assemblage as one made according to established cultural standards. Standardisation of pottery making could reflect the level of specialisation and quantity of pottery made (Roux 2003.768). This observation is of special interest in the context of this material that was excavated outside the central set- tlement at Rakushechny Yar, which was probably a seasonal area connected with fishing (Girja, Lozovsky 2014).

The variety of pottery found at Rakushechny Yar might testify to its functional diversity: a variety of forms and volumes, as well as the use of different pottery operational sequences can be traced here. The most widespread vessel form (Form 1, made from coils with an $\mathrm{N}$-junction, slightly stretched, with a smoothed surface) could be interpreted as kitchen ware. Alongside this, there were several other categories of vessels, some of which could also have served some utilitarian purpose, while some could have played a particular role (vessels covered with ochre on the inner and outer sides; vessels for ochre storage).

The chronology of the material culture from Rakushechny Yar can be reconstructed from the ${ }^{14} \mathrm{C}$ dates of different materials: charcoal, soil, organic crust on pottery from excavation I (Belanovskaya, Timofeev 2003.Tab. 1). In addition, several dates are known for the different materials (bone, pottery, soil with charcoal and soil) from the test pit excavated in 2008 , which was dug $25 \mathrm{~m}$ from excavation I (Fig. 7).

The dates from excavation I correlate well with each other (Fig. 3), except for the dates on shell and some of the dates on charcoal and soil samples. These dates show the existence of different sites over a long period in this area. The oldest date, of an elk bone, comes from below layer 23 of the new excavation and may date the first stages of this occupation to $7970 \pm 110 \mathrm{BP}$ (SPb-729).

Dates from layers $20-17$ show that the early Neolithic complex can be placed at the turn of the $7^{\text {th }}$ millennium calBC (Figs. 3, 7), which indicates that Rakushechny Yar was occupied over a period of approx. 800 years without any great changes. Later, many changes in pottery decoration, morphology

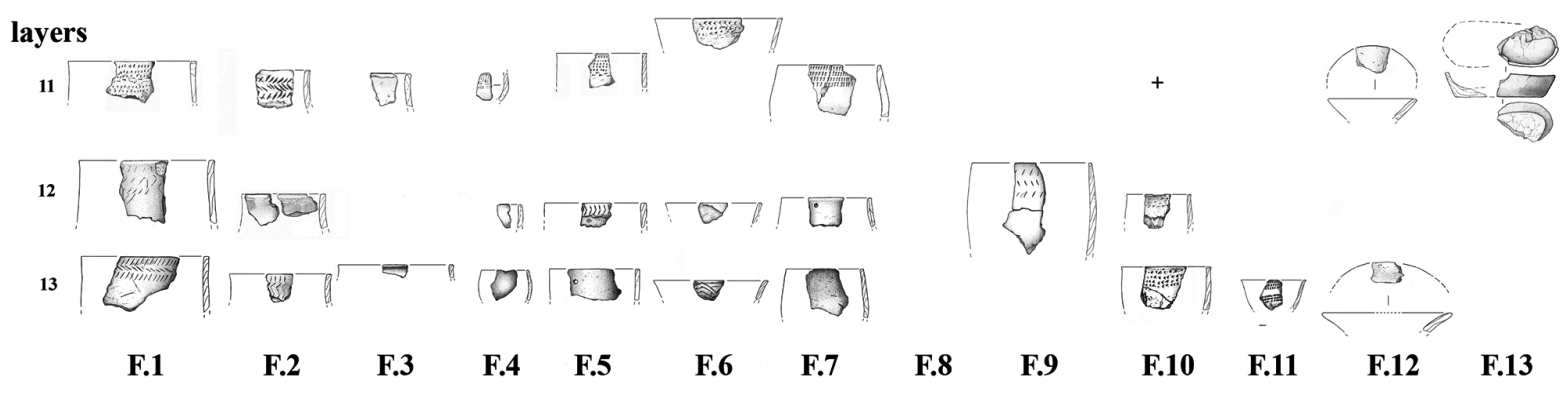

Pl. 2. Rakushechny Yar. Vessel forms in layers 13-11. 
and technology can be seen to occur over approx. 500 years (layers 16-9). The end of the Early Neolithic at Rakushechny Yar can be dated to the end of the $6^{\text {th }}$ millennium calBC (Fig. 3).

The buried soil X (Aleksandrovsky et al. 2009.Fig. 4 ) deposited at the base of the cultural layers of the test pit is dated to $7380 \pm 100 \mathrm{BP}$ (Ki-15181), i.e. a period later than the lowest layers of Belanovskaya's excavation I (Fig. 4). This suggests that this area was inhabited approx. 600 years later. It was located on ground higher than the area of excavation I, and the soil was formed here when the occupation of the excavation I area started. The beginning of occupation of this area correlates with the period when cultural layer 20 of excavation I was formed. The differences in ${ }^{14} \mathrm{C}$ dates and the number of cultural layers (their thickness and characteristics) supports Belanovskaya's hypothesis that the cultural layers identified at the shore, in test-pits and in the numerous excavations at Rakushechny Yar in different parts of the island cannot be simply correlated. Synchronous layers might also occupy different hypsometric positions. This 'diversity' is evidence of asynchronic and repeated occupation of this area.

The origin of the Rakushechny Yar complex raises many questions and discussions. The appearance of this complex can be dated to the first quarter of the 7th millennium calBC (Timofeev et al. 2004; Davi- son et al. 2009; Aleksandrovsky et al. 2009; Tsybriy et al. 2014), i.e. contemporaneous with Early Neolithic (ceramic) complexes in the Near East (Belanovskaya, Timofeev 2003). During this time, the oldest pottery centres were formed in the steppe areas of Eastern Europe, which could have occurred under the influence of Neolithic cultures in the Caucasus (Belanovskaya 1995.181-182), whereas the Southern Caucasus area was within the zone of influence of early Anatolian Neolithic cultures during the Pre-Pottery Neolithic B period (PPNB) (Kiguradze, Menabde 2004.353). However, no such ancient sites with pottery have survived in the Caucasus, where Early Neolithic complexes have been dated to the end of the $7^{\text {th }}$ and to the $6^{\text {th }}$ millennium calBC (Arimura et al. 2010; Hansen et al. 2007; Hamon 2008).

However, based on a range of similar features, i.e. similar forms of pottery and similar ceramic techniques (the use of coils or slabs, the simplicity of pottery, rare use of decoration) (Vandiver 1987.9-23; M. le Mière, Picon 1999.5-16; Nishiaki, M. le Mière 2005.59-63; Voigt 1983), the existence of specific types of tools with a longitudinal groove, similar to tools distributed in the Levant and Western Mesopotamia (Arimura et al. 2010.80), adobe architecture and the proximity of radiocarbon dates, we might also suppose direct infiltrations from the Near East to the Lower Don Region. Relations be-

\begin{tabular}{|c|c|c|c|c|c|}
\hline Layers & organic crust & charcoal & soil with charcoal & Bone & Shell \\
\hline \multirow[b]{2}{*}{ layer 2} & & & $5290 \pm 260$ (Le-5327) & & \\
\hline & & $4830 \pm 90($ Le-5383) & $6300 \pm 300$ (Le-5343) & $4180 \pm 100($ Le-5428) & \\
\hline layer 3 & & $4360 \pm 100(B \ln 704)$ & & & \\
\hline \multirow[b]{2}{*}{ layer 4} & & & & $5060 \pm 230$ (Le-5140) & \\
\hline & & & & $6300 \pm 90($ Le-5482) & \\
\hline \multirow[b]{2}{*}{ layer 5} & & & $6320 \pm 40$ (Le-5582a) & $5920 \pm 90$ (Le-5479) & \\
\hline & & & $6440 \pm 35$ (Le-5582b) & & $7840 \pm 105(\mathrm{Ki}-955)$ \\
\hline layer 8 & & $6070 \pm 100(B \ln 1177)$ & & & \\
\hline layer 9 & & & & & $7180 \pm 250$ (Le-5344) \\
\hline \multirow[b]{3}{*}{ layer 15} & $6930 \pm 100(\mathrm{Ki}-6478)$ & & & & \\
\hline & $6950 \pm 100(\mathrm{Ki}-6479)$ & & & & \\
\hline & $7040 \pm 100 \quad(\mathrm{Ki}-6480)$ & & & & \\
\hline \multirow[b]{2}{*}{ layer 18} & $6841 \pm 40 \quad(\cup a-41365)$ & & & & \\
\hline & $\left(\delta^{13} C-28,0^{* * *}\right)$ & & & & \\
\hline \multirow[b]{2}{*}{ layer 19} & $7156 \pm 41 \quad(U a-41364)$ & & & & \\
\hline & $\left(\delta^{13} C-28, O^{* * *}\right)$ & & & & \\
\hline \multirow[b]{5}{*}{ layer 20} & $7290 \pm 50$ (Ua-37097) & & & & \\
\hline & $\left(\delta^{13} C-28,6\right)$ & & & & \\
\hline & $7690 \pm 110 \quad(K i-6475)$ & & & & \\
\hline & $7860 \pm 130(\mathrm{Ki}-6477)$ & & & & \\
\hline & $7930 \pm 40(\mathrm{Ki}-6476)$ & & & $|7970 \pm 110 B P(S P b-729) *|$ & \\
\hline
\end{tabular}

Fig. 3. ${ }^{14} \mathrm{C}$ dates made on different materials found at excavation I of Rakushechny Yar (* dates obtained on material found during recent excavations; ** estimated value). 
tween the steppe areas of Eastern Europe from the Black Sea to the Azov Sea with Armenia and Central Anatolia could also be evidenced by finds of obsidian that originated from deposits located in the latter regions (Biagi et al. 2014). Recent research has revealed traces of the penetration of Near Eastern cultural traditions dating to an even earlier period into these areas (Gorelik et al. 2014). This might testify to multiple cases of penetration by bearers of Near Eastern cultural traditions with different components of the 'Neolithic package' in the Lower Don region.

\section{Sites in the Lower Volga River basin}

A detailed description of early Lower Volga Neolithic sites can be found in publications by Aleksander A.
Vybornov (Vybornov 2008; Vybornov et al. 2012; 2013). We present here a description of pottery of this region based on these publications and also on the results of pottery analyses from different sites. The pottery assemblages are presented here in the chronological order proposed by Vybornov (2008) based on an analysis of pottery, the stone industry and the radiocarbon dates of organic crusts on pottery, and other materials attributed to different periods.

Sites in the Lower Volga River basin are divided into two groups, one on the left bank and another on the right bank of the river (Map 1) (Vybornov 2008). Almost all the pottery from the North Caspian area was made from silts with organic solutions (definitions

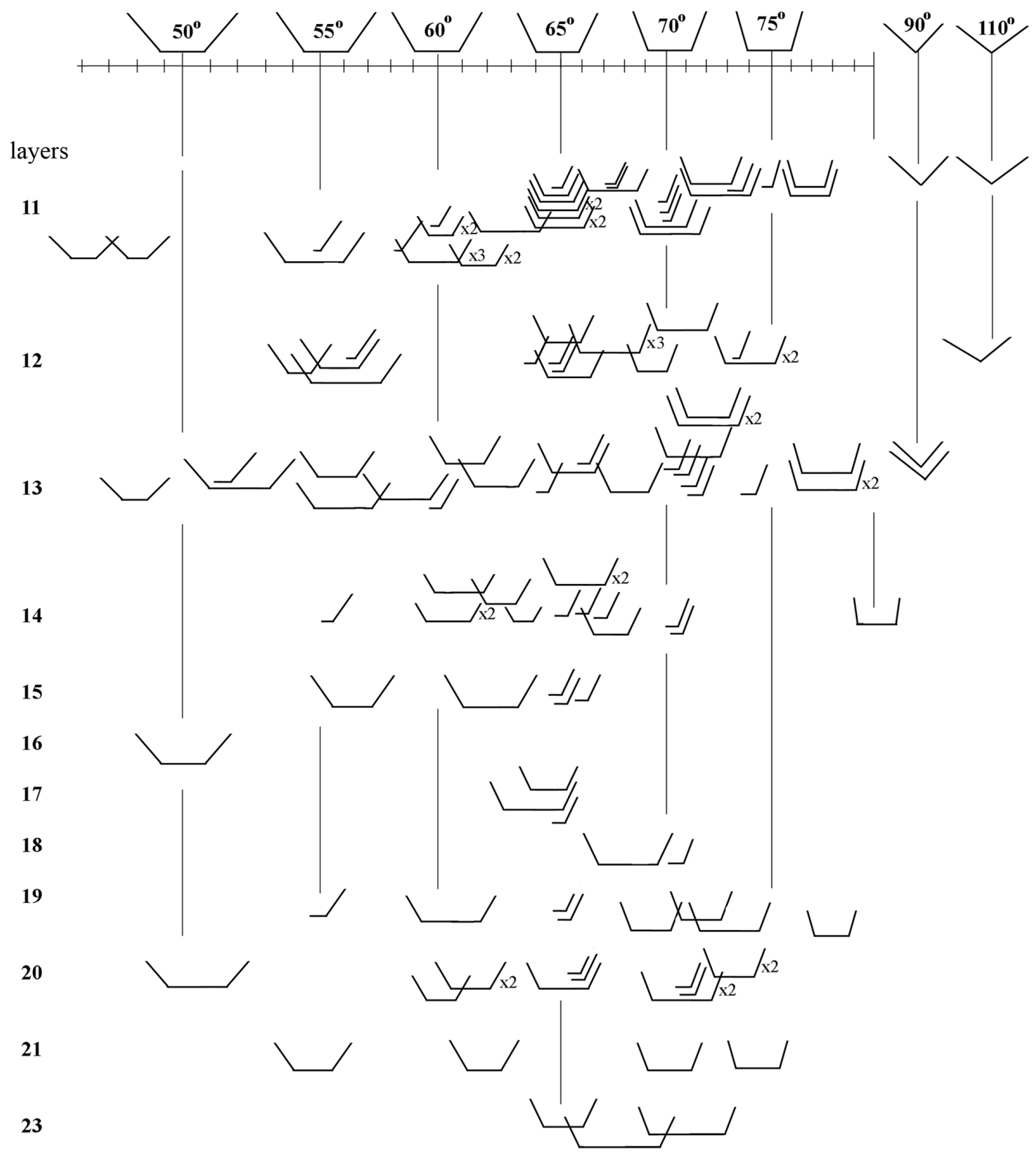

Pl. 3. Rakushechny Yar. Divergence angles and base' diameters in layers 23-11. 
of raw materials by Vasilieva 1999; 2010); later, shells were incorporated into the paste (Vasilieva, Vybornov 2012). According to Irina N. Vasilieva, the Early Neolithic pottery of the North Caspian was made from slabs put together in spirals (Vasilieva 1999.84-85). Large vessels could have been made from slabs organised into blocks or with the moulding of vessels (Vasilieva 1999.86-91).

The early chronological stage of the Volga left-bank group (termed Kairshak-Tenteksor) includes the Kugat IV and Kulagaisi sites (Tab. 12.1-3). Vessels were made from paste with crushed shells and organic remains; they have straight walls and round bases. Decoration did not cover the whole surface, and was made by incised lines or oval-form impressions (Vybornov 2008). The dates of the first and second stages overlap and have aroused some controversy, which needed to be explained (Tab. 12). The conservation of Mesolithic traditions in the stone industry can be traced during this stage (Vybornov 2008). These sites could reflect the first wave of distribution of pottery-making traditions in this region.

The second chronological stage is represented by Kairshak I-IV (Tab. 12.6-30) and Burovaya 42. Vessels were made from sandy silts with a natural admixture of shells and organic material; they usually have bowl-like forms, with flat, somewhat concave bases. Decoration consists of various motifs (Vybornov 2008), while some fragments of undecorated pottery, similar to the undecorated pottery from the lower layers at Rakushechny Yar, were found at Kairshak III.

The third chronological stage includes Tenteksor I, Je-kolgan, Kachkarstau, Kyzyl-hak II. Vessels were made from sandy silts with a natural admixture of shell and organic material; they have flat bases with a simple or complex profile and flat or roundish rims. Most of the vessels are decorated with oval or quadrangular-form impressions, while geometrical curvilinear decoration is typical of this material ( $\mathrm{Vy}$ bornov 2008).

The Jangar-Varfolomeevskaya group was located on both banks of the Lower Volga. Tu-buzgu-huduk represents the earliest stage; pottery was made from clay paste with a mixture of sand and organic remains. Vessels have straight walls and closed forms; bases are flat and roundish. Decoration is rather simple, consisting of triangular and oval impressions in the upper part of the vessels forming horizontal rows of impressions and zigzags (Vybornov 2008).
The second chronological stage includes the second and third layers at the Jangar site (Tab. 13.11, 2326) and layer 3 at Varfolomeevka (Tab. 13.1-10, 1223). Vessels from Varfolomeevka were made from silt, similar to those from the North Caspian area. The pottery in layer 3 was made with shell temper. Most of the vessels from layers 2 and $2 \mathrm{a}$ were made from silty clay (Vasilieva 2010). This pottery was constructed from coils; the outer surface was polished, and the inner surface smoothed by a comb tool or grass (Yudin 2004). The coils could have been stretched and attained up to $2.5-3 \mathrm{~cm}$. Most vessels have straight walls; bases are predominantly flat, but slightly concave compared to the flat bases at Rakushechny Yar, and they rarely have a clear angle between the base and the wall. Pottery was decorated with triangular impressions, usually covering the upper part of the vessels or the whole pot; a technique with dot impressions was applied. Complex motifs consisting of zigzags and geometrical figures, as well as simple compositions of horizontal lines, are typical. Rims are slightly cut, straight and roundish (Yudin 2004).

The vessels from Jangar were made from silts, although some pots were made from silty clay. Bases are usually flat, although some vessels have round bases, with straight walls, and a closed or complex profile. Decoration on the upper part is in the form of triangular, oval and quadrangular impressions. The decorative compositions vary (Vybornov 2008; Koltsov 1988).

Several major ceramic forms were identified (Pls. 45), which include open vessels (form 1 , form 8 ), vessels with a complex profile (form 2.1, form 4.1, form 7) and small bowls (form 10). The volumes of vessels from the earliest sites (Kugat IV, Kulagai-si) are $0.3,1.5$ and 3 litres. Vessels from Varfolomeevka (layer 3) have volumes of $0.15,0.3,0.8,1.5-2.2$ and 5 litres. Later, large closed vessels were more common (form 4.2, form 12), open big vessels (form 8), and small bowls (form 11). The volumes of vessels increased in this period: for examples, at Kairshak III, vessels of $0.7,1.2-1.5,3,5-6$ and 13-14 litres were found. We might also suppose, due to the diameter of the upper parts, that there were larger vessels in the assemblage. The volumes of examples from Varfolomeevka (layer 2B) are 4, 6 and 18.5 litres, and from Jangar (layer 2) 0.5 and 10 litres.

\section{Sites in the Middle Volga basin}

The description of the ceramic collection from this region is based on an analysis of published materi- 
als and observations made when analysing some of the ceramic finds from various sites.

Elshanskaya pottery appeared in the second quarter of the $7^{\text {th }}$ millennium calBC in the Middle Volga basin. Its origin may have been connected to the penetration of the conical ware ceramic tradition, poorly decorated, from south-western areas, from the Eastern Caspian area and Aral region, bypassing the Caspian plain (Vasilliev, Vybornov 1988.24). It has also been proposed that this ceramic tradition originated in this region, which was only slightly influenced by southern groups (Kuz'mina, Lastovskii 1995.43). Early Neolithic complexes in the southern foreststeppe of the Volga-Ural region can be found at sites located on the banks of the Samara, Sok and Tok rivers (Morgunova 1995.14).

Three chronological complexes can be identified in the Elshanskaya materials (Tabs. 14-15): early, middle and late (Vasilieva, Vybornov 2012). Vessels were predominantly made from silty clay with an admixture of organic solutions and grog (crushed pottery) (Vasilieva 2011; Vybornov 2008.241). Vessels were made from slabs on different moulds or arranged by sections (Vasilieva 2011). The 'paddle and anvil technique' was also applied. Wall thickness is $3-4 \mathrm{~mm}$. The coil technique with $\mathrm{N}$-junction appears on some vessels from Staroelshanskaya II and Chekalino IV. Smoothing and polishing were the main types of surface treatment. Pottery was fired at low temperatures (Vasilieva 2011).

The early Elshanskaya complex includes undecorated pottery with thin walls, with predominantly S-profile or straight walls and conical bases. Although it might be supposed that flat bases would have been among the most ancient types (Andreev 2012).

The middle Elshanskaya complex includes pottery with decoration (short incisions on the rim, incised lines organised in a net, bands of impressed dots, combined with incised decoration and triangular impressions). This pottery was rarely made from silt. Vessels have round and flattened bases (Vasilieva, Vybornov 2012).

The late Elshanskaya complex includes vessels with thick straight walls, with a row of impressions below the rim, and predominantly flat bases (found at Krasny Gorodok, Vilovatovskoe and other sites in the northern Middle Volga basin). Pottery surface treatment included smoothing with a comb (Vasilieva, Vybornov 2012a).
A separate group that includes undecorated vessels with round and flat bases found at Vilovatovskoe was also attributed to Elshanskaya culture (Vasilieva, Vybornov 2012a).

According to the analysis of reconstructed vessel forms published in the literature, Elshanskaya pottery had estimated volumes of $0.16,1.5-2$ and 5-6 litres in the early stage. The forms of the vessels are open with an out-turned rim (Pls. 4-5), made from combined cones (form 2.1,2.2), cylinder and ellipse (form 3), closed forms (form 5), and cylindrical ware (form 9). The pottery of the middle complex had volumes of 1, 2.5, 5-6, 10 and 40 litres. As well as bowls (form 11), the pottery forms of this stage are $3,5,4.1,6$, and 12 . The forms of flat-bottomed ware of the final stage have the same form as the conical ware (forms 3, 5). The vessel volumes are 0.25, 0.44, 5.7, 7 and 20-23 litres. Also, small bowls with volumes of $0.11,0.15,0.22$ and 0.45 litres (form 11) were found at Ozimenki 2, Imerka 8, Lebyazhinka IV, and Ivanovskoe.

\section{Early Neolithic sites of the Dnepr-Dvina region} The basin of the Upper Western Dvina River is one of the first regions in the forest zone of Eastern Europe where pottery appeared at the beginning of the $7^{\text {th }}$ millennium calBC. This was probably the result of migrations of small groups and/or 'migrations of ideas' (Mazurkevich et al. 2006), firstly from the territory of the Lower Don and later from the Lower Volga region (Mazurkevich 1995). During the early Neolithic, various types of pottery appeared here, which have been defined as 'ceramic phases' which mark changes in pottery technology, morphology, and design (Miklyaev 1995) (Pl. 6). The analysis of pottery assemblages allows us to trace several technological, morphological and decorative traditions, the formation of which was influenced by a variety of factors. The appearance of bearers of other cultural traditions here can be traced primarily in the changes in morphology and decoration; in most cases, the technology changed little. We also deduce from our analysis that specific ceramic recipes were used for specific chaînes opératoires, which is typical of the pottery of this region.

Phase ' $a-1$ ' is represented by fourteen vessels from eight sites situated in the Serteysky (Serteya X (Fig. 8), XXII, XIV, XXXVI, 3-3) and Usviatsky (Romanovskoe, Cyganovy Nivy, Uzmen') micro-regions (Tab. 16). Vessels were made from lean kaolinite clay with a high content of clastic material, and sand and grog temper (dry clay). Vessels were constructed with the 
coiling technique, with coils set at an obtuse angle in vertical and horizontal section $0.9-2 \mathrm{~cm}$ high (Tab. 17). Wall thickness is from $0.7-0.8 \mathrm{~cm}$ to $1-$ $1.1 \mathrm{~cm}$. Traces of a comb-like tool left in the course of surface roughening after covering the vessel with a layer of liquid clay are visible on both surfaces; they show through a thin layer of surface covering that had been polished or smoothed. The vessels are not decorated. They have a straight form, with a slightly out-turned flat edge, which is characteristic only of the pottery of this phase, and there is one example of a pointed rim.

Phase ' $a$ '. Thirteen vessels from four sites in the Serteysky (Serteya X, 3-3; Rudnya Serteyskaya) and Usvyatsky micro-regions (Poloneika) have been discovered. They were made from clay of hydromica composition, with an admixture of sand and grog or aleurite sediments without temper, and constructed with the coiling technique (Tab. 19). Coils are at an obtuse angle in the vertical and horizontal sections, which are $0.9-2 \mathrm{~cm}$ high. The wall thickness varies from $0.7-0.8 \mathrm{~cm}$ to $1-1.1 \mathrm{~cm}$; some fragments have $0.4-0.6 \mathrm{~cm}$ thick walls. The vessels have traces of comb on both surfaces showing through a thin layer of polished covering. The vessels were decorated with incised short lines, put in horizontal and diagonal rows. The pottery forms from this phase have pointed to round and straight rims.

Phase ' $b$ '. Ninety-nine vessels (Tab. 20) were discovered at 22 sites located in the Serteysky (Serteya X, XII, XIX, XX, XXI, XXII, XXIV, XIV, XXVII, XXXV 3-1, 3-3, 3-4, 3-5, 3-6; Rudnya Serteyskaya), Usviatsky (Usviaty II, Uzmen', Romanovskoe, Cyganovy Nivy) and Sennitsky (Froly I, Dubokrai I) microregions. Several vessels were made from aleurite sediments without temper. However, most were made from two types of clay paste: aleurite and hydromica sediments (lean clay) with an admixture of sand, and grog, as well as more plastic clay with a greater percentage of grog and sand. A change in raw material sources can be noted in the pottery of phase 'b': gyttja sediments from lakes and aleurite from riverside areas were used most frequently as raw material. Furthermore, this trend was associated with the occurred river transgression and, consequently, the appearance of new sources of raw materials.

The pottery technology of phase 'b' differs little from phase 'a'. The coil technique was used, and slabs could also have been added. Surfaces were polished or smoothed. It is possible that they were coated with a thin layer of liquid clay and then roughened, as in the case of the other phases. Vessels are decorated with drop-like impressions, triangular impressions and incisions. Compositions consisting of motifs in horizontal rows predominate. There are also compositions with a rhomboid and rectangular grid system similar to nets. Vessels take different forms: open with straight, out-turned rims, as well as some with parallel walls and round-edged rims, with either conical or rounded bases.

\section{The cultural and chronological position of the early Neolithic ceramic complex in the Dnepr- Dvina region}

In 1964, and later in 1985, when this pottery was discovered, it was almost impossible to define its Early Neolithic age based on similarities. These similarities came from different, rather distant territories (as far as the north Caspian region), and the materials were from mixed artefact assemblages (Miklyaev et al. 1987). In addition, radiocarbon dates were not available for most of these complexes. In recent years, with the appearance of new materials and radiocarbon dates of Early Neolithic pottery from Eastern Europe, these proposed similarities have come to be accepted by a wide scientific community.

At the beginning of the Atlantic Period, two waves of pottery traditions penetrated this region. This happened during a period of significant climatic change. This is also supported by greater anthropogenic influence on the ecosystem and palaeo-lakes in comparison with the preceding Boreal period (Mesolithic). However, the traditions of phase ' $a-1$ ' pottery did not become very widespread, whereas the traditions of phase ' $a$ ' demonstrate their further development in this region, as does the appearance of phase 'b' pottery decorated with triangular impressions.

Ceramic phases ' $a$ ' and ' $a-1$ ', which constitute the oldest pottery traditions, appeared in this region, each with their own origin. Phase ' $a-1$ ' seems to be the oldest in this region, given the typological-technological analysis and ${ }^{14} \mathrm{C}$ dates, and could have originated in the pottery of the Rakushechny Yar site. It was dated to $8380 \pm 55 \mathrm{BP}(\mathrm{Ua}-37099)$ based on organic crust from a vessel fragment. A very low percentage of $\delta^{13} \mathrm{C}(-33.8 \%)$ in the charred food crusts is evidence of a hard-water reservoir effect, so the date could be older (Fischer, Heinemeier 2003). This pottery fragment was found in the lowest sandy layer at Serteya XIV. The sand was probably formed at the same time as that on the site at Rudnya Serteyskaya. Based on these assumptions and also analogues in Neolithic cultures in southern part of East- 


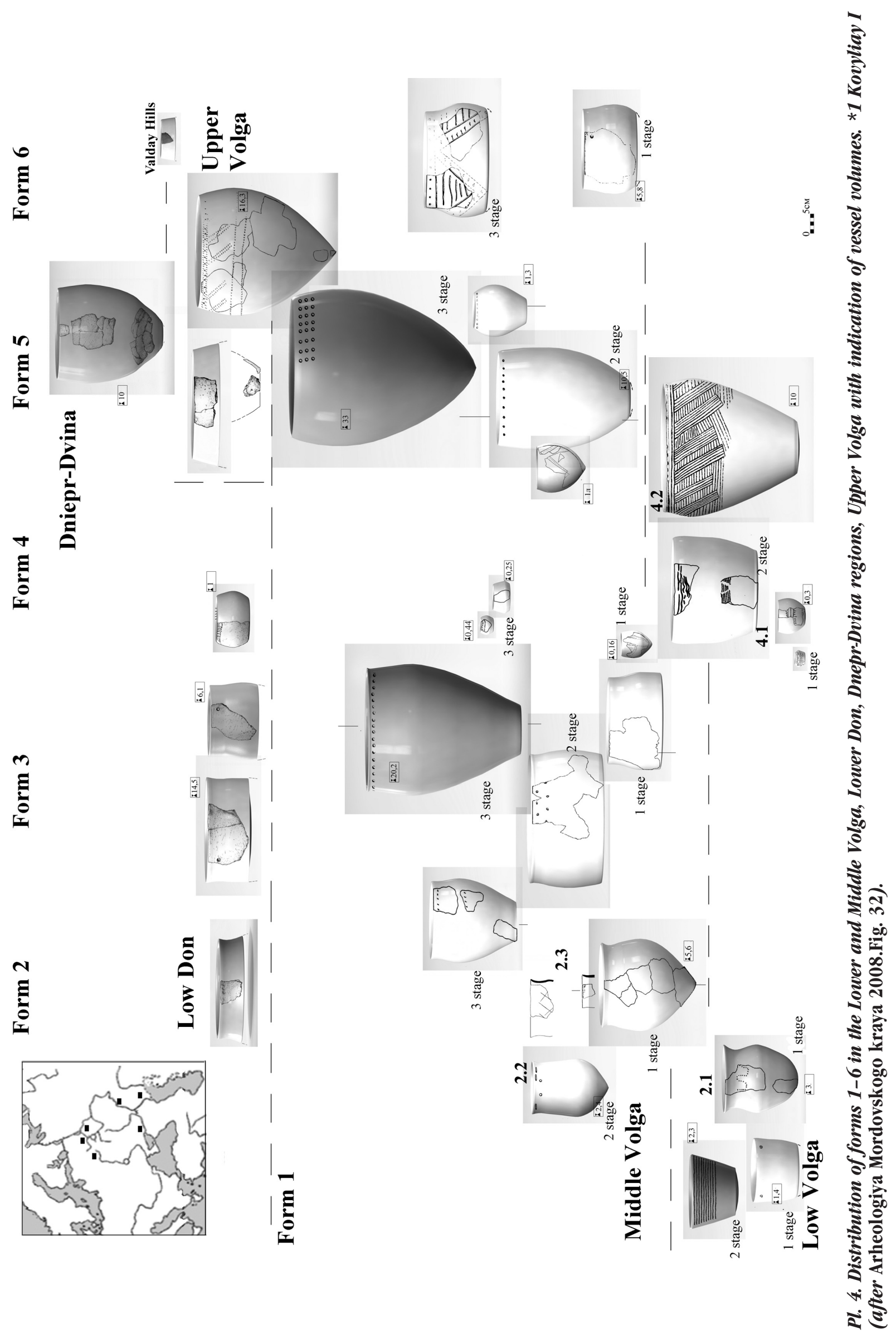


ern Europe, the appearance of these materials might date to the first half of the $7^{\text {th }}$ millennium $\mathrm{BC}$.

The pottery of phase ' $a$ ' is similar to the early Neolithic pottery of the Northern Caspian region and to the range of cultures in the Middle and Upper Don region (Smol'aninov 2005.Fig. 2.8), the Middle and Upper Volga (Vybornov et al. 2000.186, Fig. 1; Krainov-Khotinsky 1977.Fig. 4.3, 14, 15) and the SuraMoksha basin. The traditions with triangular impressions first found in materials of phase 'a' continued into phase ' $b$ '. It was probably during this time that the influence of this decoration of steppe cultures first spread in different directions along the basins of the Middle Volga, Middle Don, Upper Volga, Sursko-Moksha basin, Desna, Upper Dvina, Upper Dnepr and Valdai valley.

At the Rudnya Serteyskaya site, phase 'a' pottery was found in a layer of sand, and some of the fragments attributed to this phase were found in a layer of bluish, sandy, shell-rich gyttja (Fig. 9). The formation of the sandy layer occurred in the Boreal period, when regression occurred, and the interruption in sedimentation can be traced in the pollen diagram (Dolukhanov et al. 1989).

At Serteya X, fragments of phase ' $a$ ' pottery were also found in a layer of bluish, sandy, shell-rich gyttja. There were three horizons of cultural layers divided by sterile inter-layers of bluish-grey sandy gyttja. This gyttja deposit at the bottom of the lake basin is dated to $7800+120 \mathrm{BP}(\mathrm{Lu}-4255)-7510 \pm 140$ $\mathrm{BP}$ (Lu-4256), which is when sites with phase 'a' pottery existed on the lake shore. This can be proved by dates obtained from organic crust on phase ' $a$ ' pottery. The accumulation of gyttja, which covered the sand at Rudnya Serteyskaya, and on which phase ' $b$ ' artefacts from the Serteya $X$ site were found, can be dated to $7380 \pm 130 \mathrm{BP}(\mathrm{Lu}-4258)-6680 \pm 150$ BP (Lu-4277) due to the investigation of bore-hole 63 (Arslanov et al. 2009). Some of the vessels from this phase were found in layer A-2 at Serteya $\mathrm{X}$, which correlates with the date obtained on wood from the same layer, $7300 \pm 80 \mathrm{BP}$ (Le-5260).

The dating of organic crust from phase ' $a$ ' pottery corresponds to $7870 \pm 100 \mathrm{BP}(\mathrm{Ua}-37100)\left(\delta^{13} \mathrm{C}=\right.$ $-31.7 \%$ ) (Rudnya Serteyskaya site) and $7150 \pm 50$ $\mathrm{BP}(\mathrm{Ua}-37098)(\delta 13 \mathrm{C}=-31.2 \%)$ at Serteya $\mathrm{X}$, layer b. Thus, we may suppose that phase 'a' pottery may be dated to $6800-6100$ calBC. Despite rather high negative values of $\delta^{13} \mathrm{C}$, the determination of $\delta^{13} \mathrm{C}$ alone cannot be a definite marker, which shows the older age of the sample, as some plant materials also have high negative $\delta^{13} \mathrm{C}$ values (Boudin et al. 2010).

\section{Discussion}

The oldest pottery traditions in Eastern Europe were distinguished on the basis of specific technologicaltypological characteristics and radiocarbon dates. We might also suppose the existence of intermediate sites located between the southern and northern areas with the oldest pottery assemblages, which is also evidenced by the analysis of Early Neolithic materials found in mixed complexes with pottery dating to different periods. For example, undecorated pottery similar to the Rakushechny Yar ceramic tradition was identified at sites located in the Middle Don and Upper Volga regions.

We propose two different models of Neolithisation for the territory of Eastern Europe. The first relates to the 'standard' spread of the 'package of innovations' that marked the beginning of the Neolithic period (pottery, a productive economy, architecture, stone vessels that can be found, for example, at Rakushechny Yar), and to the formation of 'primary' centres of Neolithisation in the Lower Don, Northern Caspian and Middle Volga Regions (which could have been influenced by other early Neolithic ceramic cultures with origins beyond Eastern Europe). The advantages of components of the 'Neolithic package' were not evident to tribes of hunter-gatherers, who could estimate the value of these components and choose those that suited them, namely pottery, which seemed not to be the most important part of the package. The competitive character of different economic strategies can be seen at this stage and the 'readiness' of local populations to admit definite innovations would be important. The absence of a productive economy could be explained by specific characteristics of the local natural environment: low fertility of soils, long winters and rich water and forest resources (Dolukhanov 1996), as well as the low population numbers in ecological niches. Later on, cultural impulses began to diffuse from those centres that have been archaeologically fixed through pottery - 'ceramic waves' - throughout Eastern Europe (Mazurkevich et al. 2013).

The second model is 'septentrional' - the appearance of only one component of the 'Neolithic package' - pottery, and the formation of 'secondary' ceramic centres. It is important to note that the appearance of pottery-making skills, their dispersed distribution, and further expansion and development in 


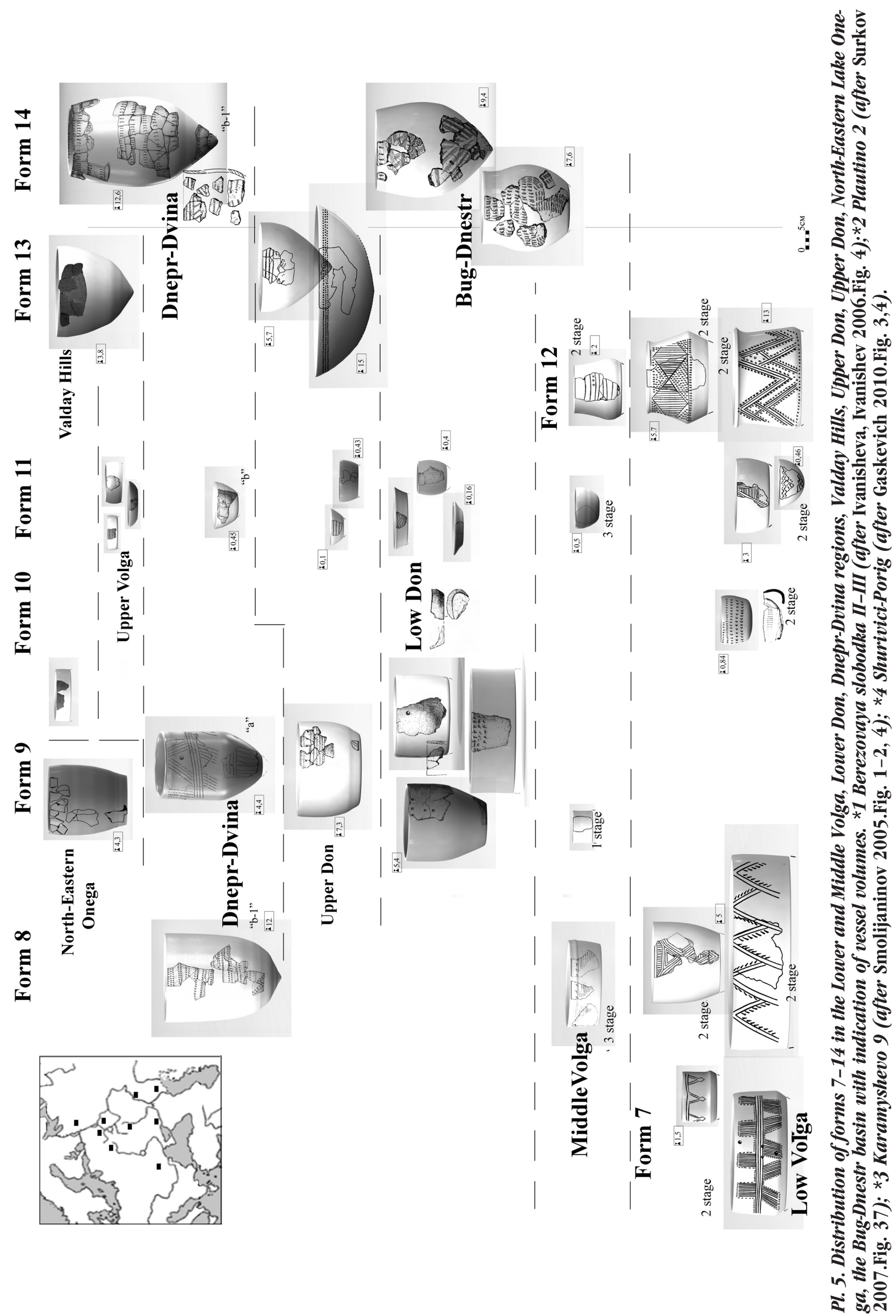




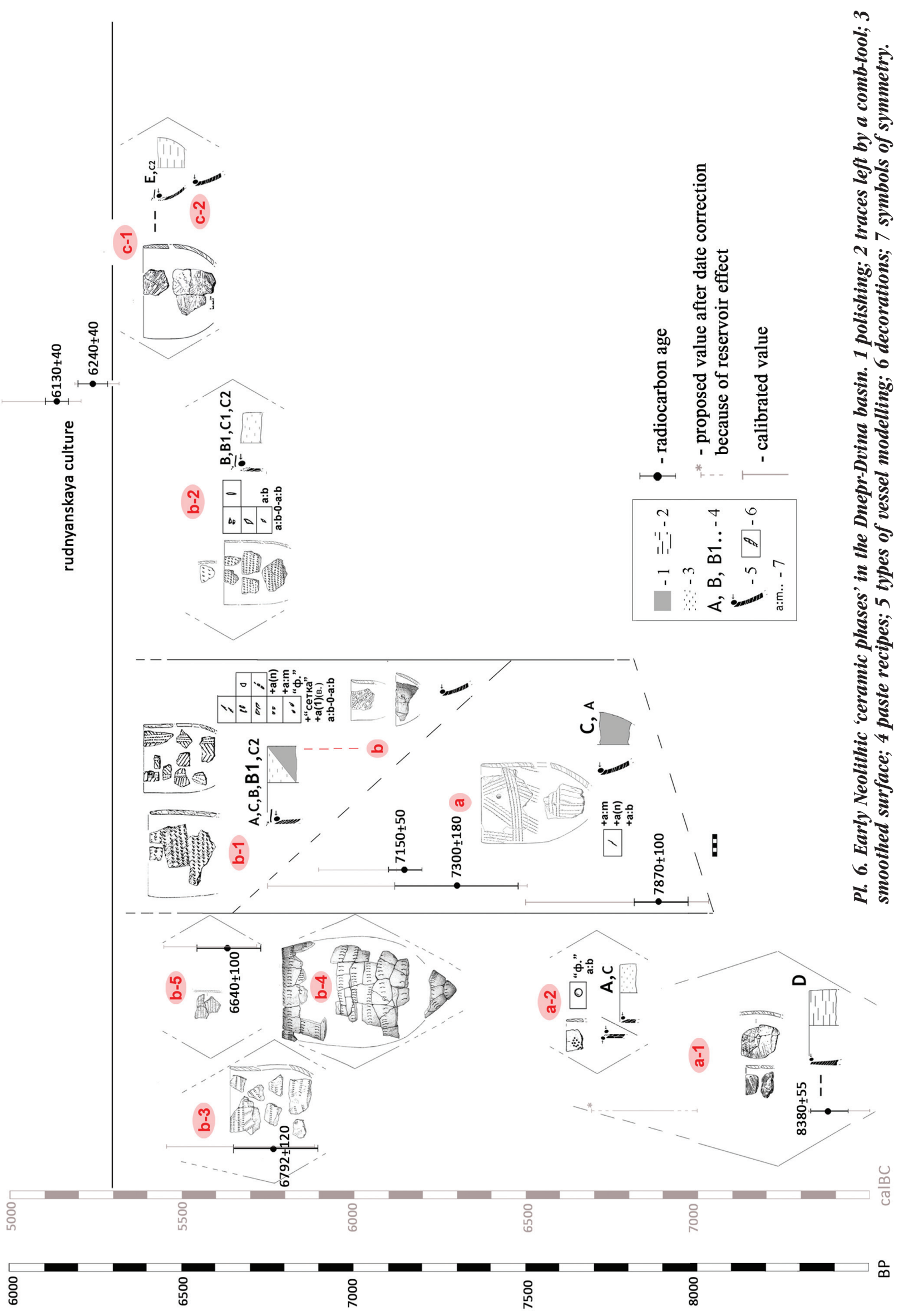


Eastern Europe are two different processes. We suggest that it is necessary to divide the process of 'Neolithic package' diffusion and formation of the oldest ceramic assemblages (related to the first model) and further distribution of pottery traditions in the Mesolithic milieu from other, secondary, centres situated in forest and steppe-forest zone. The end of the development of the first Early Neolithic traditions can be regarded as the end of the early Neolithic that happened in different regions at different times.

The appearance of pottery should not be regarded as merely a simple feature. The fact that similar pottery traditions were distributed over a great area in a short period probably had definite reasons. Some techniques, artefacts, materials and designs appear to be trans-cultural and distributed in other regions, whereas the zone of distribution of other items is limited to their place of origin (see Martineau 2000. 226). The preciseness in copying pottery technology, choice of raw materials, design and forms of vessels suggest the conservation of initial traditions in the milieu of local populations over a long period, which indicates that pottery became a trans-cultural phenomenon. One of the reasons for this could be the idea of prestige and/or sacred significance of this first ceramic ware. There might be other reasons why pottery could become an object of distribution/exchange, along with a utilitarian function: the use of pottery in feasts (Heron, Craig 2008), the high aesthetic and function of certain vessels, their content (Moore 1995.47) and prestigious character (Hayden 1998) etc.

Several facts could support the hypothesis that pottery and/or the idea of pottery making was distributed over great distances in various regions, and thus be additional evidence of the existence of 'primary' and 'secondary' centres:

(1) the existence of vessels made from raw materials that come from deposits in other parts of a microregion or from other regions, which may be evidence that they were transported over various distances (Mazurkevich et al. 2013);

(2) the similarity of decorative, technological and morphological pottery traditions found in different areas;

3 the existence of particular vessels that differed in technological, morphological and decorative features from the pottery assemblage of a site. Such 'imports' can be found in materials from the Northern Caspian (Kairshak III), the Upper Volga (Sakhtysh IIa) and the Dnepr-Dvina regions (Uzmen').
'Primary' centres became areas from where potterymaking traditions spread to other territories. One of these centres was in the Lower Don River in the first quarter of the $7^{\text {th }}$ millennium calBC. Based on the described evidence, this centre could be regarded as an initial area for the formation of Early Neolithic cultures in Eastern Europe (Mazurkevich, Dolbunova 2012; Mazurkevich et al. 2013). In the process of distribution further to the north, this 'Neolithic package' lost most of its constituents, and the only indicator of a new epoch that is archaeologically visible is pottery with definite technological, morphological and decorative features. Similar chaînes opératoires and their modifications were distributed in areas in the Dnepr-Dvina region (phase ' $a-1$ '), Upper Volga region (Zamostie 2 is an example, see (Mazurkevich et al. 2013a), Sakhtysh sites, type 4 and 7), the Upper Dnepr region, and Valday region (type 1). Similar vessels can be also found in the Middle and Lower Don regions. However, this pottery did not become the only basis for following the formation of Early Neolithic complexes, as at the Raksuhechny Yar site.

The tradition of pottery decorated with triangular impressions, individual linked impressions and lines first appeared in the basin of the Lower Volga and Northern Caspian in the first quarter of the $7^{\text {th }}$ millennium calBC (Vybornov 2008). The early pottery in the Lower Volga region is accompanied by a stone industry, which, according to researchers of this region, have Mesolithic traits (Vybornov 2008) and could have been connected with the first stage in the distribution of ceramic traditions. This conservation of Mesolithic flint traditions in complexes accompanying the first pottery can be also found in different areas of Western and Eastern Europe (Lozovsky 2001; Polkovnikova 2003; Nikitin 2013.26; Sinyk 1986; Robinson et al. 2013), although some researchers also outline the possibility that different complexes were mechanically mixed (Viskalin 2013). Early Neolithic materials in the Northern Caspian have analogues in Neolithic material from the Caucasus, Lower Volga and Azov areas, and the central Asian Neolithic (Vybornov 2008).

Cultural impulses from this centre can be traced over a vast territory of the forest-steppe and forest zones of Eastern Europe (Miklyaev et al. 1987; Mazurkevich 1995). In a neighbouring region, at Rakushechny Yar, a few vessels decorated with triangular impressions have been found deposited with undecorated pottery in lower layers $(23,21-11)$. Also, there were fragments of pots with typical North Caspian decoration, consisting of a triangular composi- 
tion filled by small triangular impressions (layer 19; Tab. 7.9), and a pot decorated with triangular impressions in a drawn technique with single triangular impressions (layer 11).

A small number of 'archaic' items decorated with very specific triangular impressions or in drawn technique can be found in the Dnepr-Dvina region (phases ' $a$ ' and 'b'), Upper Dnepr region, Middle and Upper Volga, and Don areas, and the Desna River, and Valday region. The North Caspian pottery traditions appeared in the forest-steppe and forest regions, were conserved and developed further independently from the 'primary' centre and did not change significantly for several hundred years. In contrast, an endogenous development of pottery occurred in the 'primary' centres, evolving more complex forms and decorations as well as changes in technology.

Another early ceramic complex at sites on the Middle Volga River - in the area of Elshanskaya culture distribution - can be dated to the first quarter of the $7^{\text {th }}$ millennium calBC. The formation of the Early Neolithic complex of the forest-steppe zone in the Volga basin can be connected to the central Asian region (Andreev 2014.13). The slab technique and ' $S$ ' pottery techniques, the use of certain raw materials, the complex forms of vessels, and decoration with impressions below the rim are typical features. A mixture of organic fluid and grog (crushed pottery) are among the most typical admixtures in the paste recipes (Vasilieva, Vybornov 2014.38), and also for pottery from other areas that might be analogical to Elshanskaya pottery. The use of organic fluid is also found in pottery from the North Caspian basin ( $\mathrm{Va}$ silieva 1999.84). Traces of organic fluid where the coils are joined, as well as a grog temper, can be found in pastes of pottery from sites located on the Sukhona River (Ivanischeva 2009.278). Grog temper was also used in pottery of the Elshanskaya-like culture in the Sura-Moksha basin (Vasilieva, Vybornov 2014.38) and in pottery from the Koshkinskaya site on the right bank of the Vyatka River (Gusentsova 2014.91). Pottery in the Dnepr-Dvina basin was made with another type of grog (crushed clay), which was first used in vessels from phase ' $a-1$ '.

Some types of Elshanskaya culture are similar to pottery from Rakushechny Yar (form 2), made with the ' $S$ ' technique with an admixture of grog (only in this case, crushed pottery was used). Also, the straight walls and roundish or pointed rims of the earliest stage of Elshanskaya culture are similar to forms 1 and 5 from Rakushechny Yar (Pl. 1).
The distribution of sites with Early Neolithic pottery reveals particularities in the distribution of different types throughout Eastern Europe. The distribution map of sites where pottery appeared in the first half of the $7^{\text {th }}$ millennium calBC shows a small number of such regions with the oldest dates (Map 1 ). We might suppose that such pottery would be typologically distinguishable from the later mixed pottery traditions of different regions. However, its quantity and the number of sites with these types of pottery would not be the same as in the following periods. A considerable increase in radiocarbon dates of Early Neolithic pottery can be seen in the period from 6500 to $5500 / 5300$ calBC (Map 2). The absence of radiocarbon dates for certain types of pottery did not allow an analysis of their distribution into more narrow chronological periods within this long period. Also, we might suppose the co-existence of sites with pottery of different origin. For example, in the Upper Don basin, several groups of sites with different pottery types have been found: sites with Karamyshevo-type pottery, Upper Volga culture, Elshanskaya culture and Middle Don culture (Smolianinov 2009).

\section{Could we estimate the speed of this process?}

It is assumed that the process of Neolithisation was a single event. However, it is now clear that this process could have taken a long time, such as, for example, in north-western Turkey, where this process took 2000 years from when elements of the 'Neolithic package' first appeared. It might be proposed that different forms of Neolithisation occurred simultaneously in different parts of this region (Özdoğan 2013.190-191). An interesting scenario has been offered of the population of the coastal regions of north-western Turkey (Özdoğan 2013.195), where Mesolithic groups adopted major components of the 'Neolithic package' brought by newcomers: pottery, a productive economy and definite categories of goods with a prestigious and/or high-status role. However, the habitual way of life continued: they lived in huts covered with clay, had a complex economy with hunter-gathering activities, and different types of burial. The economy practised at some of the sites in Anatolia in the $7^{\text {th }}$ millennium calBC was also complex, based on a combination of cattle husbandry, hunting, fishing and collecting shellfish $(\ddot{O} z-$ doğan 2013.174). Shellfish occupied a considerable place in ancient diets at some sites, where specialised storage pits have been found (Özdoğan 2013.182). Similar accumulations and pits with shellfish were 
also found at the Rakushechny Yar (Belanovskaya 1995) and Surskaya sites (Telegin 1996.44).

The distribution of pottery traditions from the three centres described above, according to ${ }^{14} \mathrm{C}$ dates ( $\mathrm{Ti}$ mofeev et al. 2004), occurred in a short period along the main water routes of Eastern Europe flowing in a meridional direction, while at first, rivers flowing in latitudinal directions formed natural barriers to the distribution of these traditions. Small groups moved and settled in different areas, the traces of which are difficult to see archaeologically, bringing innovations into the Mesolithic milieu - parts of the 'Neolithic package' - of which pottery became one of the most frequent and well accepted.

According to ethnographic data, a widespread uniformity of pottery styles must exist in communities of hunters-gatherers due to the movement of individuals between groups (Hodder 1982). This process may be termed a 'migration of ideas' in cases when physical migration is virtually undetectable. Established in a new place, these 'centres' of innovation began to be 'secondary' centres from which ceramic traditions began to diffuse and develop gradually among people in the surrounding regions. Thus, in the Dnepr-Dvina region, this process is reflected in the appearance of Rakushechny Yar pottery traditions in the first stage, which did not continue and were not adopted by local populations. Triangular impressions as decorative traditions and techniques of coil modelling with the use of polishing and smoothing with a comb-like tool from the Lower Volga North Caspian centre then appeared here. This tradition was conserved in the local cultural milieu and became widespread.

One of the factors that could have influenced the distribution of pottery traditions in specific regions might be climatic changes accompanied by climate cooling and aridisation, which occurred in the second half of the 7 th millennium calBC over a wide area of Europe (Weninger et al. 2009; Spiridonova, Aleshinskaya 1999), including the steppe and foreststeppe of Eastern Europe. This could have led to the forest zone with its huge forests and rich food resources attracting people from more southern areas (Arslanov et al. 2009; Mazurkevich 1995).

The study of the morphology of the earliest pottery from Eastern Europe shows the existence of vessels with predominantly flat and round bases during the first stage in the Rakushechny Yar assemblage, as well as at sites in the Lower Volga, the first stage of Upper Volga culture, and also, probably, in the materials from the Middle Volga River, north-eastern Lake Onega and the Dnepr-Dvina region. Vessels with a conical base spread later and were typical of the forest zone, but much less of forest-steppe and steppe zones. This testifies to the existence of various types of vessels among hunter-gatherer groups in Eastern Europe in the first stages. While richly decorated conical vessels, which are believed to accompany hunter-gatherer communities, were not predominant, they appeared much later in Eastern Europe (see for example, Budja 2013; Piezonka 2014.272). The oldest vessels were usually made from a clay paste without temper or from sandy paste without organic temper, which has also been described for some hunter-gatherers of other areas (Skibo et al. 1989.140). On the other hand, conical vessels that appeared in different parts of Europe are often supposed to be of Eastern European origin, such as in the formation of the Ertebølle complex in Northern Europe (Gronenborn 2009.541). However, based on our own observations of the earliest Eastern European pottery and the Ertebølle complex, and also based on publications (i.e. Jennbert 2011; Glykou 2011), we conclude that these complexes are not directly related, since there are great differences in pottery technologies and forms of the vessels from both these complexes. Conical bases were highly varied in terms of technology and morphology, and the problem of their appearance and development needs to be investigated.

We suppose that the appearance of the oldest pottery in Eastern Europe might have been a much more complicated process than simply some gradual distribution of conical vessels among communities of hunter-gatherers. Pottery was included in the cultural system of local societies from the very beginning, becoming a symbol/sign, where it could have played different roles.

\section{ACKNOWLEDGEMENTS}

This research was supported by RFBR, project 13-0612057. 


\section{References}

Aleksandrovsky A. L., Belanovskaya T. D., Dolukhanov P. M., Kiyashko V. Ya., Kremenetsky K. V., Lavrentiev N. V., Shukurov A. M., Tsybriy A. V., Tsybriy V. V., Kovalyukh N. N., Skripkin V. V. and Zaitseva G. I. 2009. The Lower Don Neolithic. In P. Dolukhanov, G. Sarson and A. Shukurov (eds.), The East European Plain on the Eve of Agriculture. British Archaeological Reports IS 1964. Archaeopress. Oxford: 89-98.

Alekseev A. Y., Bokovenko N. A., Vasiliev S. S., Dergachev V. A., Zaitseva G. I., Kovaliukh N. N., Cook G., van der Plicht J., Possnert G., Sementsov A. A., Scott E. M. and Chugunov K. V. 2005. Eurasia in Scythian Time. Radiocarbon and archaeological chronology. Thesa. St. Petersburg.

Andreev K. M. 2012. Problemy periodizacii i hronologii elshanskoi kul'tury. Samarskii krai v istorii Rossii 4: 6972. (in Russian)

2014. Nekotorye aspekty vzaimodeistviya naseleniya Nizhnei i Srednei Volgi v neolite. Samarskii nauchnyi vestnik 3(8): 13-18. (in Russian)

Arheologiya Mordovskogo kraya. Kamennyi vek, epoha bronzy. 2008. Izdatel'stvo Nauchno-issledovatel'skogo instituta gumanitarnyh nauk pri Pravitel'stve Respubliki Mordoviya. Saransk. (in Russian)

Arimura M., Badalyan R., Gasparyan B. and Chataigner C. 2010. Current Neolithic research in Armenia. Neo-Lithics 1(10): $77-85$.

Barnard A. 2007. From Mesolithic to Neolithic modes of thoughts. Going over: the Mesolithic-Neolithic transition in North-Western Europe. Proceedings of the British Academy 144: 5-19.

Belanovskaya T. D. 1964. Otchet o rabote Nizhnedonskoi arheologicheskoi ekspedicii v 1964 g. Archival data. (in Russian)

1995. Iz drevneishego proshlogo Nizhnego Podon'ya: Poselenie vremeni neolita i eneolita Rakushechnyi Yar. Izdatel'stvo St Peterburgskogo universiteta. S. Petersburg. (in Russian)

Belanovskaya T. D., Timofeev V. I. 2003. Mnogosloinoe poselenie Rakushechnyi Yar (Nizhnee Podonie) i problemi neolitizacii Vostochnoi Evropi. In V. I. Timofeev (ed.), Neolit - Eneolit yuga i neolit severa Vostochnoi Evropy. Novie materiali, issledovaniya, problemi neolitizacii regionov. Rossiyskaya Akademiya Nauk. Institut materialnoy kulturi. St Petersburg: 14-21. (in Russian)

Bentley A. 2007. Mobility, specialization and community diversity in the Linearbandkeramik: isotopic evidence from the skeletons. In A. Whittle, V. Cummings (eds.), Going over: the Mesolithic-Neolithic transition in Northwest Europe. Proceedings of the British Academy 144. Oxford University Press. Oxford: 117-140.

Berezina N. S., Vybornov A. A., Stavickii V. V. and Berezin A. Yu. 2013. Ranneneoliticheskaya stoyanka V'yunovo ozero I v Srednem Posurie. Tverskoi arheologicheskii sbornik 9: 195-201. (in Russian)

Berger J.-F., Guilaine F. 2009. The 8200 calBP environmental change and the Neolithic transitions: a Mediterranean perspective. Quaternary International 200: 31-49.

Biagi P., Gratuze B., Kiosak D. V., Tubolzev 0. V. and Popandopulo Z. H. 2014. The Neolithic obsidians from southeastern Ukraine: first characterization and provenance determination. Anatolia 40: 1-20.

Boudin M., van Strydonck M., Crombé P., De Clercq W., van Dierendonck R., Jongepier H., Ervynck A. and Lentacker A. 2010. Fish reservoir effect on charred food residue ${ }^{14} \mathrm{C}$ dates: are stable isotope analyses the solution? Radiocarbon 52(2-3): 697-705.

Budja M. 2010. The neolithisation of South-Eastern Europe: From Y-Chromosome dispersals to Ceramic Figurines. In D. Gronenborn, J. Petrasch (eds.), The Spread of the Neolithic to Central Europe. International Symposium, Mainz 24 June - 26 June 2005. RGZM - TAGUNGEN 4. Verlag des Römisch-Germanischen Zentralmuseums Mainz. Mainz: 107-141.

2013. Neolithic pots and potters in Europe the end of 'demic diffusion' migratory model. Documenta Praehistorica 40: 39-55.

Cauwe N., Dolukhanov P., Kozlowski J. and van Berg P.-L. 2007. Le Néolithique en Europe. Armand Colin. Paris.

Cetlin Yu. B. 2008. Neolit centra Russkoi ravniny. Ornamentaciya keramiki $i$ metodika periodizacii kul'tur. Grifi K. Tula. (in Russian)

Close A. 1995. Few and far between: early ceramics in North Africa. In W. K. Barnett, J. W. Hoopes (eds.), The emergence of pottery: Technology and innovation in ancient societies. Smithsonian Institution Press. Washington DC: 23-37.

Cohen D. J. 2014. The advent and spread of early pottery in East Asia: new dates and new considerations for the world's earliest ceramic vessels. Journal of Austronesian studies 4(2): 55-92. 
Cvetkova N. A. 2011. Rannii neolit Verhnego Povolzh'ya: nekotorye itogi izucheniya. Rossiiskii arheologicheskii ezhegodnik 4: 148-182. (in Russian)

Davison K., Dolukhanov P. M., Sarson G. R., Shukurov A. and Zaitseva G. I. 2007. A Pan-European model of the Neolithic. Documenta Praehistorica 34: 139-154.

2009. Multiple Sources of the European Neolithic: Mathematical Modelling Constrained by Radiocarbon Dates. In P. M. Dolukhanov, G. R. Sarson and A. M. Shukurov (eds.), The East European Plain on the Eve of Agriculture. British Arachaeological Reports IS 1964. Archaeopress. 0xford: 197-211.

Demoule J.P. (ed.) 2007. La révolution néolithique en France. Éditions La Découverte et Inrap. Paris.

Dolukhanov P. M., Gey N. A., Miklyayev A. M. and Mazurkiewicz A. N. 1989. Rudnya-Serteya, a stratified dwellingsite in the upper Duna basin (a multidisciplinary research). Fennoscandia archaeological 6: 23-27.

Dolukhanov P., Shukurov A. 2009. Modelling the Neolithic dispersal in northern Europe. Documenta Praehistorica 36: 35-47.

Dolukhanov P. M. 1996. The Early Slavs: Eastern Europe from the Initial Settlement to the Kievan Rus. Longman. London.

2000. Istoki etnosa. Izdatel'stvo Evropeiskii dom. St. Petersburg. (in Russian)

Fort J. 2009. Mathematical Modelling of the Neolithic Transition: a Review for Non-Mathematicians. In P. M Dolukhanov., G. R. Sarson and A. M. Shukurov (eds.), The East European Plain on the Eve of Agriculture. British Archaeological Reports IS 1964. Archaeopress. Oxford: 211-217.

Feugier F. G., Sarson G. R., Shukurov A. and Dolukhanov P. M. 2009. Population Spread Along Self-organized Paths. In P. M. Dolukhanov, G. R. Sarson and A. M. Shukurov (eds.), The East European Plain on the Eve of Agriculture. British Arachaeological Reports IS 1964. Archaeopress. Oxford: 217-229.

Fischer, Heinemeier J. A. 2003. Freshwater reservoir effect in ${ }^{14} \mathrm{C}$ dates of food residue on pottery. Radiocarbon 45(3): 449-466.

Gaskevich D. L. 2010. Severo-pontiiskoe impresso: proishozhdenie neoliticheskoi keramiki s grebenchatym ornamentom na yuge Vostochnoi Evropy. Stratum plus 2: 213-251.

Gibbs K., Jordan P. 2013. Bridging the Boreal forest. Siberian archaeology and the emergence of pottery among prehistoric hunter-gatherers of North Eurasia. Sibirica 12(1): 1-38.

Girya E. Yu., Lozovskii V. M. 2014. Sravnitel'nyi morfologicheskii analiz polnoty tehnologicheskih kontekstov kamennyh industrii. In G. A. Hlopachev, S. A. Vasil'ev (eds.), Kamennyi vek: ot Atlantiki do Pacifiki. Zamyatninskii sbornik. Vyp. 3. Muzei antropologii i etnografii. Rossiyskaya Akademiya Nauk; Institut istorii materialnoy kulturi. Rossiyskaya Akademiya Nauk. Sankt Peterburg: 5284. (in Russian)

Glushkov I. G. 1996. Keramika kak arheologicheskii istochnik. Izdatelstvo In-ta arheologii i etnografii SO. Rossiyskaya Akademiya Nauk. Novosibirsk. (in Russian)

Glykou A. 2011. Neustadt L. A. 156: a submarine site from the Late Mesolithic-Ertebølle and earliest Neolithic-Funnel Beaker in Northern Germany - first results of the typological and technological analysis of the ceramics. In S. Hartz, F. Luth and T. Terberger (eds.), Early pottery in the Baltic - dating, origin and social context. International Workshop at Schleswig from 20th to 21st October 2006. Bericht der Römisch-Germanischen Komission 89. Verlag Philipp von Zabern. Darmstadt/Mainz: 277-286.

Gorelik A. F., Cybrii A. V. and Cybrii V. V. 2014. 0 chem povedali cherep tura, topor i zhenskie statuetki: $\mathrm{k}$ probleme nachal'noi neolitizacii Nizhnego Podon'ya. Stratum plus. 2: 249-284. (In Russian)

Greenfield H. J. 2010. The Secondary products revolution: the past, the present and the future. World Archaeology 42(1): 29-54.

Gronenborn D. 2009. Transregional culture contacts and the Neolithisation process in Northern Central Europe. In P. Jordan, M. Zvelebil (eds.), Ceramics Before Farming. The Dispersal of Pottery Among Prehistoric Eurasian Hunter-Gatherers. University College London Institute of Archaeology Publications. Left Coast Press. Walnut Creek: 527-550.

2010. Migration, acculturation and culture change in western temporate Eurasia, 6500-5000 calBC. Documenta Praehistorica 30: 79-91.

Gurina N. N. 1997. Otnositel'naya i absolyutnaya hronologiya pamyatnikov kamennogo veka Volgoverhov'ya. In I. V. Vereshagina, I. N. Gurina, T. B. Krylova, G. V. Sinicyna, V. I. Timofeev and V. Ya. Shumkin (eds.), Kamennyi vek Verhnevolzhskogo regiona 2. Institut istorii materialnoy kulturi. Rossiyskaya Akademiya Nauk. Sankt Peterburg: 221-227. (in Russian)

Gusencova T. M. 2014. Ranneneoliticheskii kompleks Koshkinskoi stoyanki na pravoberezh'e r. Vyatki. Samarskii nauchnyi vestnik 3(8): 90-94. 
Guilane J., Manen C. 2007. From Mesolithic to Early Neolithic in the western Mediterranean. In A. Whittle, V. Cummings (eds.), Going over: the Mesolithic-Neolithic transition in Northwest Europe. Proceedings of the British Academy 144. Oxford University Press. Oxford: 21-51.

Hamon C. 2008. From Neolithic to Chalcolithic in the Southern Caucasus: economy and macrolithic implements from Shulaveri-Shomu sites of Kwemo-Kartli (Georgia). Paléorient 34(2): 85-135.

Hansen S., Mirtskhulava G. and Bastert-Lamprichs K. 2007. Aruchlo: A Neolithic Settlement Mound in the Caucasus. Neo-Lithics 1(7): 13-19.

Hartz S., Lubke H. and Terberger T. 2007. From fish to sheep and cattle: new research into the process of neolithisation in northern Germany. In A. Whittle, V. Cummings (eds.), Going over: the Mesolithic-Neolithic transition in Northwest Europe. Proceedings of the British Academy 144. Oxford University Press. Oxford: 567-594.

Hartz S., Kostyleva E., Piezonka H., Terberger T., Tsydenova N. and Zhilin M. 2012. Hunter-gatherer pottery and charred residue dating: new results on early ceramics in the Northern Eurasian forest zone. Radiocarbon 54(3-4): 1033-1048.

Hayden B. 1998. Practical and Prestige Technologies: The Evolution of Material Systems. Journal of Archaeological Method and Theory 5(1): 1-55.

Heron C., Craig 0. 2008. Pottery use among late foragers and early farmers in the Baltic: New molecular and isotopic investigations. In S. Hartz, F. Luth and T. Terberger (eds.), Early pottery in the Baltic - dating, origin and social context. International Workshop at Schleswig from $20^{\text {th }}$ to $21^{\text {st }}$ October 2006. Bericht der Römisch-Germanischen Komission 89. Verlag Philipp von Zabern. Darmstadt/Mainz: 11-26.

Hodder I. 1982. Symbols in action. Ethnoarchaeological studies of Material Culture. Cambridge University Press. Cambridge.

Ivanisheva M. V. 2009. Kompleksy s tychkovo-nakol'chatoi keramikoi v Nizhnem Posuhon'e. Izvestiya Samarskogo nauchnogo centra Rossiiskoi Akademii Nauk 11(6): 277-281. (in Russian)

Ivanisheva M. V., Ivanishev A. M. 2006. Poselenie rannego neolita na Nizhnei Suhone. Tverskoi arheologicheskii sbornik 6: 287-299. (in Russian)

Jennbert K. 2011. Ertebølle pottery in Southern Sweden a question of handicraft, networks, and creolization in a period of neolithisation. In S. Hartz, F. Luth and T. Terber- ger (eds.), Early pottery in the Baltic - dating, origin and social context. International Workshop at Schleswig from $20^{\text {th }}$ to $21^{\text {st }}$ October 2006. Bericht der Römisch-Germanischen Komission 89. Verlag Philipp von Zabern. Darmstadt/Mainz: 89-110.

Karmanov V. N. 2008. Neolit evropeiskogo severo-vosto$k a$. Komi nauchnyi centr Ural'skogo otdeleniya Rossiiskoi Akademii Nauk. Syktyvkar. (in Russian)

Kulkova M. A., Mazurkevich A. N., Nesterov E. M. and Sinai M. Y. 2014. The analysis of stable isotopes and radiocarbon dating of artefacts of the Neolithic site Serteya II (Dvina-Lovat' interfluve). In A. Mazurkevich, M. Polkovnikova and E. Dolbunova (eds.), Archaeology of lake settlements IV-II mill BC: chronology of cultures and natural-climatic rhythms. Materials of international conference dedicated the semi-centennial anniversary of the researches of lake dwellings in North-Western Russia, SaintPetersburg, 13-15 November 2014. The State Hermitage Museum. Russian academy of sciences. Institute for the history of material culture. Herzen State University. UMR 8215 CNRS Trajectoires. Saint-Petersburg: 33-39.

Kiguradze T., Menabde M. 2004. The Neolithic of Georgia In A. Sagona (ed.), View from the Highlands. Archaeological Studies in Honour of Charles Burney. Ancient Near Eastern Studies Supplement Series 12. Peeters Publishers. Leuven: 345-398.

Kol'cov P. M. 1988. Neoliticheskoe poselenie Dzhangar. In N. Ya. Merpert (ed.), Arheologicheskie kul'tury Severnogo Prikaspiya. Mezhvuzovskii sbornik nauchnyh trudov. Kuibyshevskaya oblastnaya tipografiya. Kuibyshev: 5292. (in Russian)

Kotova N. S. 2002. Neolitizaciya Ukrainy. Shlyah. Lugansk. (in Russian)

Krainov D. A., Khotinskii N. A. 1977. Verhnevolzhskaya ranneneoliticheskaya kul'tura. Sovetskaya arheologiya 2: 42-67. (in Russian)

Krainov D. A. 1996. Verhnevolzhskaya kul'tura. In S. V. Oshibkina (ed.), Neolit Severnoi Evrazii. Nauka. Moskva: 166-172. (in Russian)

Kuz'mina 0. V., Lastovskii A. A. 1995. Stoyanka Krasnyi gorodok. In Drevnie kul'tury lesostepnogo Povolzh'ya. Samara: 25-50.

Lozovskii V. M. 2001. Problemy perehoda ot mezolita $k$ neolitu $v$ Volgo-Okskom mezhdurech'e po materialam stoyanki Zamost'e 2. Unpublished PhD thesis. Institut istorii material'noi kul'tury. St Petersburg. (in Russian) 
Lychagina E. L., Cygvinceva T. A. 2013. Sravnitel'nyi analiz ranneneoliticheskih kul'tur Prikam'ya. Vestnik Permskogo universiteta 1(21): 22-36.

Martineau R. 2000. Poterie, techniques et société. Études analytiques et expérimentales à Chalain et Clairveaux (Jura) entre 3200 et 2900 av. J.-C. Unpublished $\mathrm{PhD}$ thesis at l'Université de Franche-Comté.

2001. La fabrication des poteries du groupe de Clairvaux ancien (Jura, France), entre 3025 et 2980 avant J.-C. Expérimentations et analyses du façonnage et des traitements de surface. In L. Bourguignon, M.-C. FrereSautot (eds.), EPUISE. Préhistoire et approche expérimentale. Éditions Mergoil. Paris: 173-186.

Mazurkevich A. N., Dolbunova E. V. and Kul'kova M. A. 2013. Drevneishie keramicheskie tradicii Vostochnoi Evropy. Rossiiskii arheologicheskii ezhegodnik 3: 27-108. (in Russian)

Mazurkevich A. N., Miklyaev A. M. 1998. 0 rannem neolite mezhdurech'ya Lovati i Zapadnoi Dviny. Arheologicheskii sbornik Gosudarstvennogo Ermitazha 33: 731. (in Russian)

Mazurkevich A. N., Dolukhanov P. M., Shukurov A. M. and Zaitseva G. I. 2006. Pottery-making revolution in Northern Eurasia. In Abstract book, "Man and Environment in Pleistocene and Holocene: Evolution of Waterways and Early Settlement of Northern Europe". International conference. St. Petersburg, April 14-16, 2006. Environment Evolution Commission IGU and Institute for History of Material Culture Russian Academy of Science. St. Petersburg.

Mazurkevich A. N., Dolbunova E. V. 2012. The most ancient pottery and Neolithisation of Eastern Europe. Fontes Archaeologici Posnanienses 48: 143-159.

Meadows J. 2014. Food-crust ingredients and their implications for the chronology of Neolithic pottery. In A. Mazurkevich, M. Polkovnikova and E. Dolbunova (eds.), Archaeology of lake settlements IV-II mill BC: chronology of cultures and natural-climatic rhythms. Materials of international conference dedicated the semi-centennial anniversary of the researches of lake dwellings in North-Western Russia, Saint-Petersburg, 13-15 November 2014. The State Hermitage Museum. Russian academy of sciences. Institute for the history of material culture. Herzen State University. UMR 8215 CNRS Trajectoires. Saint-Petersburg: 40-44.

Miklyaev A. M., Mazurkevich A. N., Doluhanov P. M. and Zaiceva G. I. 1987. 0 rannem neolite severa Smolenskoi oblasti i yuga pskovskoi oblasti. In Zadachi sovetskoi arheologii v svete reshenii XXVII s'ezda KPSS (Suzdal' 1987). Moskva: 169-170. (in Russian)
Miklyaev A. M. 1995. Kamennyi-zheleznyi vek v mezhdurech'e Zapadnoi Dviny i Lovati. Peterburgskii arheologicheskii vestnik 9: 8-42. (in Russian)

Moore A. M. T. 1995. The inception of pottery in Western Asia and its impact on economy and society. In W. Barnett, J. W. Hoopes (eds.), The emergence of pottery: Technology and innovation in ancient societies. Smithsonian Institution Press. Washington, DC: 39-53.

Morgunova N. L. 1995. Neolit i eneolit yuga lesostepi Volgo-Ural'skogo mezhdurech'ya. Izdatel'stvo Orenburgskogo gosudarstvennogo pedagogicheskogo universiteta. Orenburg. (in Russian)

le Mière M., Picon M. 1999. Les débuts de la céramique au Proche-Orient. Paléorient 24(2): 27-48.

Nikitin V. V. 2013. Neolitizaciya lesnogo Volgo-Kam'ya. Povolzhskaya arheologiya 1(3): 22-31. (in Russian)

Nishiaki Y., le Mière M. 2005. The oldest neolithic pottery of Upper Mesopotamia: New evidence from Tell Seker AlAheimar, the Khabur, Northest Syria. Paléorient 31(2): $55-68$.

Oshibkina S. V. 1996. Ponyatie o neolite. In S. Oshibkina (ed.), Neolit Severnoi Evrazii. Nauka. Moskva: 6-9. (in Russian)

Özdoğan M. 2011. Archaeological evidence on the westward expansion of farming communities from Eastern Anatolia to the Aegean and the Balkans. Current Anthropology 52(4): 415-430.

2013. Neolithic Sites in the Marmara Region: Fikirtepe, Pendik, Yarimburgaz, Toptepe, Hoca Ceslme and Asagi Pinar. In M. Özdoğan, N. Başgelen and P. Kuniholm (eds.), The Neolithic in Turkey. New Excavations and New Research, Vol. 5: Northwestern Turkey and Istanbul. Archaeology \& Art Publication. Istanbul: 167-269.

Philippsen B. 2014. Can modern samples indicate past freshwater reservoir effects? In A. Mazurkevich, M. Polkovnikova and E. Dolbunova (eds.), Archaeology of lake settlements IV-II mill BC: chronology of cultures and natural-climatic rhythms. Materials of international conference dedicated the semi-centennial anniversary of the researches of lake dwellings in North-Western Russia, Saint-Petersburg, 13-15 November 2014. The State Hermitage Museum. Russian academy of sciences. Institute for the history of material culture. Herzen State University. UMR 8215 CNRS Trajectoires. Saint-Petersburg: 28-32.

Piezonka H. 2014. Jäger, Fischer, Topfer. Wildbeutergruppen mit früher Keramik in Nordosteuropa im 6. und 5. Jahrtausend v. Chr. Archäologie in Eurasien 30. Habelt-Verlag. Bonn. 
Polkovnikova M. E. 2003. Planigraficheskaya i "kul'turnaya" struktura ranneneoliticheskogo poseleniya Serteya XIV. In A. Mazurkevich (ed.), Drevnosti Podvin'ya: istoricheskii aspekt. Izdatelstvovo Gosudarstvennogo Ermitazha. St Petersburg: 99-106. (in Russian)

Robinson E., Sergant J. and Crombé P. 2013. Late Mesolithic armature variability in the Southern North Sea basin: implications for forager: Linearbandkeramik contact models of the transition to agriculture in Belgium and Southern Netherlands. European Journal of Archaeology 6 (1): 3-20.

Roux V. 2003. Ceramic Standardization and Intensity of Production: Quantifying Degrees of Specialization. American Antiquity 68(4): 768-782.

Sinyuk A. T. 1986. Naselenie basseina Dona v epohu neolita. Izdatel'stvo Voronezhskogo gosudarstva. Voronezh. (in Russian)

Skibo J. M., Schiffer M. B. and Reid K. C. 1989. Organictempered pottery: an experimental study. American Antiquity 54(1): 122-146.

Smirnov A. S. 1991. Neolit verhnei i srednei Desny. Institut arheologii Akademii nauk SSSR. Moskva. (in Russian)

Smol'yaninov R. V. 2005. Novirann'oneolitichni materiali z nakol'chastoyukeramikoyu na Verhn'omu Donu. Kam'yanadoba Ukraini 7: 123-132. (in Russian)

2009. Rannii neolit Verhnego Dona. Unpublished PhD thesis. Lipeckii gosudarstvennyi pedagogicheskii universitet. Lipeck. (in Russian)

Smol'yaninov R. V., Surkov A. V. 2014. Rannii neolit Verhnego Dona. Samarskii nauchnyi vestnik 3(8): 161-171. (in Russian)

Spiridonova E. A., Aleshinskaya A. S. 1999. Periodizaciya neolita-eneolita Evropeiskoi Rossii po dannym palinologicheskogo analiza. Rossiiskaya arheologiya 1: 23-33. (in Russian)

Stavickii V. V., Hrekov A. A. 2003. Neolit-rannii eneolit lesostepnogo Posur'ya i Pohoper'ya. Izdatel'stvo Saratovskogo Univerziteta. Saratov. (in Russian)

Surkov A. V. 2007. Neoliticheskie pamyatniki Srednego Pohoper'ya. Voronezhskii gosudarstvennyi pedagogicheskii universitet. Voronezh. (in Russian)

Tallavaara M., Pesonen P. and Oinonen M. 2010. Prehistoric population history in eastern Fennoscandia. Journal of Archaeological Science 37: 251-260.
Telegin D. Ya. 1996. Surskaya kul'tura (Nizhnii Dnepr i stepnoe Levoberezh'e). In Oshibkina S. (ed.), Neolit Severnoi Evrazii. Nauka. Moskva: 40-45. (in Russian)

Timofeev V. I., Zaiceva G. I., Dolukhanov P. M. and Shukurov A. M. 2004. Radiouglerodnaya hronologiya neolita Severnoi Evrazii. Teza. St Petersburg. (in Russian)

Tovkailo M. T. 2010. Rann'oneolitichnii gorizont poseleniya Gard i problema neolitizacii pivnichno-zahidnogo Nadchornomorya ta Pobuzhzhya. Kamyana doba Ukraini 13: 208-228. (in Russian)

Tsybriy A. V., Dolbunova E. V., Mazurkevich A. N., Tsybriy V. V., Gorelik A. F., Motuzaite Matuzevichiute G. and Sablin M. V. 2014. Novye issledovaniya poseleniya rakushechnyi yar v 2008-2013 g. Samarskii nauchnyi vest$n i k$ 3(8): 203-214. (in Russian)

Tyurina I. M. 1970. Neolit Verhnego Podneprov'ya. Sovetskaya arheologia 3: 40-52. (in Russian)

Urban Yu. N. 1996. Stoyanka Zabel'e pamyatnik rannego neolita severnogo Valdaya. Tverskoi arhaeologicheskii sbornik 2: 235-244. (in Russian)

Vandiver P. B. 1987. Sequential slab construction; a conservative southwest Asiatic ceramic tradition, ca. 70003000 BC. Paléorient 13(2): 9-35.

Vasil'eva I. N. 1999. Goncharstvo naseleniya Severnogo Prikaspiya v epohu neolita. Voprosy arheologii Povolzh'ya. Sbornik statei 1: 72-96. (in Russian)

2010. K voprosu o razvitii goncharnyh tradicii v Povolzh'e v epohu neolita. In Kul'turnaya specifika Volgo-Surskogo regiona v epohu pervobytnosti. Chuvashskii gosudarstvennyi institut gumanitarnyh nauk. Cheboksary: 97-118. (in Russian)

2011. Ranneneoliticheskoe goncharstvo Volgo-Ural'ya (po materialam elshanskoi kul'tury). Arheologiya, etnografiya i antropologiya Evrazii 2(48): 70-81. (in Russian)

Vasil'eva I. N., Vybornov A. A. 2012. Novye podhody k izucheniyu neolitizacii v Srednem Povolzh'e. Samarskii krai v istorii Rossii 4: 61-68. (in Russian)

2012a. Neoliticheskii keramicheskii kompleks Vilovatovskoi stoyanki: morfologiya i tehnologiya. Arheologicheskie pamyatniki Orenburzh'ya 10: 23-42. (in Russian)

2014. Neoliticheskogo goncharstvo Sursko-Mokshanskogo mezhdurech'ya. Samarskii nauchnyi vestnik 3(8): 35-54. (in Russian) 
Vasil'ev I. B., Vybornov A. A. 1988. Neolit Povolzh'ya. Kuybyishevskiy gosudarstvennyiy pedagogicheskiy institut. Kuibyshev. (in Russian)

Viskalin A. V. 2014. Problema kontaktov stepnogo i lesostepnogo Povolzh'ya v rannem neolite. Samarskii nauchnyi vestnik 3(8): 54-57. (in Russian)

Voigt M. M. 1983. Hajii Firuztepe, Iran: The neolithic settlement. University Museum Monograph 50. University Museum. Philadelphia.

Vybornov A. A. 2008. Neolit Volgo-Kam'ya. Izdatel'stvo Samarskogo gosudarstvennogo pedagogicheskogo universiteta. Samara. (in Russian)

Vybornov A., Zaitseva G., Kovaliukh N., Kulkova M., Possnert G. and Skripkin V. 2012. Chronological problems with neolithization of the northern Caspian Sea area and the forest-steppe Povolzhye region. Radiocarbon 54 (3-4): 795-799.

Vybornov A. A., Kovalyuh N. N., Lastovskii A. A., Mamonov A. E., Morgunova N. L. and Skripkin V. V. 2008. Novye radiouglerodnye daty dlya neolita lesostepnogo Zavolzh'ya. In V. V. Stavickii (ed.), Arheologiya Vostochnoevropeiskoi lesostepi. Sbornik materialov 2-1. Penza: KopiRizo: 96-105.

Vybornov A. A., Andreev K. M., Barackov A. V., Kul'kova M. A., Kol'cov P. M., Yudin A. I., Dzhall T., Goslar T., Oinonen M., Possnert G. and B. Philippsen 2013. Novye dannye po radiouglerodnoi hronologii neolita lesostepnogo i stepnogo Povolzh'ya. Izvestiya Samarskogo nauchnogo centra Rossiiskoi Akademii Nauk 15(5): 254-260. (in Russian)
Vybornov A. A., Kolev Yu. I. and Mamonov A. E. (eds.) 2000. Istoriya Samarskogo Povolzh'ya s drevneishih vremen do nashih dnei. Kamennyi vek. Samarskiy nauchnyiy tsentr Rossiyskoy Akademii nauk. Samara. (in Russian)

Weninger B., Alram-Stern E., Bauer E., Clare L., Danzeglocke U., Jöris O., Kubatzki C., Rollefson G., Todorova H. and van Andel T. 2006. Climate forcing due to the 8200 calyr BP event observed at Early Neolithic sites in the eastern Mediterranean. Quaternary Research 66: 401-420.

Weninger B., Clare L., Rohling E., Bar-Yosef O., Bohner U., Budja M., Bundschuh M., Feurdean A., Gebel H-G., Joris O., Linstadter J., Mayewski P., Muhlenbruch T., Reingruber A., Rollefson G., Schyle D., Thissen L., Todorova H. and Zielhofer C. 2009. The Impact of Rapid Climate Change on prehistoricsocieties during the Holocene in the Eastern Mediterranean. Documenta Praehistorica 36: 7-59.

Yudin A. I. 2004. Varfolomeevskaya stoyanka $i$ neolit stepnogo Povolzh'ya. Izdatel'stvo Saratskogo Unverziteta. Saratov. (in Russian)

Zaiceva G. I., Kul'kova M. A. and Mazurkevich A. N. 2014. Radiocarbon chronology of middle-late Neolithic of DneprDvina region. In A. Mazurkevich, M. Polkovnikova and E. Dolbunova (eds.), Archaeology of lake settlements IV-II mill BC: chronology of cultures and natural-climatic rhythms. Materials of international conference dedicated the semi-centennial anniversary of the researches of lake dwellings in North-Western Russia, Saint-Petersburg, 1315 November 2014. The State Hermitage Museum. Russian academy of sciences. Institute for the history of material culture. Herzen State University. UMR 8215 CNRS Trajectoires. Saint-Petersburg: 67-85.

$\therefore$

\section{Appendix}

Neolithic sites with Samchinskaya-type pottery: 1 Tetereuka Noue XV; 2 Soroka I, layer 1, hor. 'a'; 3 Soroka V; 4 Cykynivka; 5 Girzheve; 6 Pechera I; 7 Korzhiv; 8 Samchinci I; 9 Samchinci II; 10 Shurivci-Porig; 11 Shimanovs'ke II; 12 Sokil'ci I, II, VI; 13 Zyan'kivci II; 14 Glyns'ke I; 15 Ladyzhin II; 16 Ladyzhin I; 17 Myt'kiv Ostriv; 18 Baz'kiv Ostriv; 19 Zavallya; 20 Zhakchik; 21 Mel'nychna Krucha; 22 Savran'; 23 Pugach 2; 24 Pugach 1; 25 Gard 4; 26 Gard 3; 27 Korma 1B; 28 Krushnyky; 29 Gyrlo Gnylopyati; 30 Lazarivka; 31 Zavalivka; 32 Borodyanka 3V; 33 Hodosivka; 34 Romankiv; 35 Mutyhy; 36 Dobryanka 1; 37 Stril'cha Skelya; 38 Kizlevyi V; 39 Semenivka 1; 40 Zlyvki; 41 Zelena Gornycya 6; 42 Zelena Gornycya 5; 43 Tuba 2; 44 Starobil's'k.

Sites in the Lower Don and Northern Azov areas: 45 Matveev kurgan; 46 Rakushechny Yar.

Lower Volga River sites. Kairshak-tenteksorskaya group: 49, 51 Kugat IV, Kulagai-si (I stage); 50 Kairshak III (II etap); Dzhangaro-varfolomeevskaya group: 47 Tu-Buzgu-Huduk I (I stage); 48 Dzhangar (2, 3 layers), 52 Varfolomeevka (3 layer) (II stage).

Site of Strumel': 197 Gastyatin type. 
Sites in the Lower Dnepr basin (surskaya culture, I stage): 194 Surskoi Island; 195 Kodachek Island; 196 Vinogradnyi Island.

Sites in the Middle Volga basin (Elshanskaya culture, middle Volga culture), Suro-Moksha basin: 53 Maksimovskaya; 54 Vilovatovskaya; 55 II Staro-Elshanskaya; 56 Ivanovskaya; 57 Krasnyi Yar VII; 58 Lebyazhinka I; 59 Lebyazhinka IV; 60 Il'inskaya; 61 Nizhnyaya Orlyanka II; 62 Chekalino IV; 63 Krasnyi Gorodok; 64 Lugovoe III; 65 Ozimenki I, II; 66 Imerka 8; 67 Utyuzh I; 68 Lake V'yunovo I; 69 Lesnoe-Nikolskoe III; 70 IV Tetyushskaya; 71 II Sherbet'skaya; 162 Gorodok I; 163 Vadovskie selisha; 164 Starodevich'e 1; 165 Russkoe Maskino 1; 166 Mashkino 1, 3; 167 Kovylyai 1, 3; 168 Volgapino; 169 Andreevka 1; 170 Krasnyi Yar; 171 Potodeevo; 172 Ekaterinovka 2; 173 Bessonovka 3; 174 Grabovo 3; 175 Podlesnoe 3, 4, 5, 7, 8; Bessonovka 1, 2; 176 Penzenskie stoyanki (Ernya, Kalashnyi zaton, Belyi omut); 177 Ust'-Kadada 1; 178 Inderka.

Sites of Volgo-Kama culture: 72 Tarhan I; 73 Koshkinskaya; 74 Kyilud II; 75 Chernushka; 76 Chernushka; 77 Levshinskaya; 78 Chashkinskoe ozero VI, VIII.

Sites of Khoper, Middle Don basin: 79 Plautino 1,2,4; 80 Rusanovo; 81 Borisoglebskie 1-3, Lovchak 7-8, Strel'bishe 4-5, Stela; 82 Kozlinovskaya; 83 Staroanninskaya; 84 Kopanishe 1, 2; 86 Monastyrskaya; 87 Droniha; 88 Cherkasskaya; 89 Inyasevo; 90 Shapkinskie stoyanki; 91 Uvarovo; 92 Mozharovka; 93 Kipec.

Sites in the Upper Don basin: 85 Yamnoe; 94 Ust'e reki Izlegoshi-2, 3; 95 Karamyshevo 1, 5, 9, 19, m. Krasnyi Bugor; 96 Yarlukovskaya protoka, Rybnoe ozero-2, 1, Punkt 207. site 'Natasha'; 97 Lake Lipeckoe; 98 Studenovka 3; 99 Kulikovka 2, Berezovka 4B, Monastyrshina 2A; 100 Vasil'evskii kordon-1,3,5, 7, 16, Podzorovo-1,2; 101 Dobroe-1, site 87: Lake Bogorodickoe, Bogorodickoe 1; 102 site 1. Shlyuz 1, p.97 v urochishe Gorodishe, site 382, 380, 100, Sokol'skii most 8, 9, 11, 3, pos. u pamyatnika Narodovol'cam; 103 settlement 2 (site 105), 6 (site 109) near Gudovskogo kordona, site 8 in Malininovsky district, site 1 near Pervomaiskoe lesnichestva, site 343, site 5, site 2 near village of Krutogor'e; 104 site 3 at the mouth of the Borovica River, site 259 (site 1 near Lake Krugloe), site 346 (site 6 near Lake Lyubovickogo), site 340 (site 7 near Barkovskii); 105 Savickoe 1; 106 location near the village of Preobrazhenovka, Buhovoe 9, 10, Glinishe, Torbeevo XV, XVII, Kriveckoe Lesnichestvo 1; 107 Kurino 1; 108 Universitetskaya 1, 3, Chertovickaya, Chernavskaya, st.Yaht-klub, Shilovskaya 1, Otrozhka; 109 Zamyatino 10; 110 Krivobor'e 2; 111 Ksizovo 6.

Sites of Desninskaya culture: 112 Zherenskaya protoka; 113 Zhereno III; 114 Vithovka I, III; 115 Chernetovo I; 200 Krasnoe V, VI, X.

Sites in the Upper Dnepr: 116 Romanovichi; 117 Strelice; 118 Borok; 119 Zaval'e; 120 Katyn' 2; 121 Katyn' 3; 122 Katyn' 1, st. 21, 6; 198 location at Kasplya lake; 199 Zaozer'e; 201 Lavki.

Sites of Dnepr-Dvina basin: 123 sites in the Serteysky micro-region; 124 sites of the Usviatsky micro-region; 125 sites in the Sennitsky micro-region.

Sites of the early stage of Upper Volga culture (including Volgo-0ka culture sites): 126 Ozerki 5, sloi III; 127 Al'ba I, III; 128 Davydkovskaya; 129 Zamost'e 2; 130 Yazykovo I; 131 Kuhmar' 1; 132 Pol'co; 133 Belivo II; 134 Maslovo boloto 8; 135 Shadrino IV; 136 Alekseevskoe I; 137 Sahtysh I, II, VIII; 138 Ivanovskoe III, V, VII; 139 Okaemovo 3, 5,18; 140 Varos; 179 Somino II; 180 Kosyachevo I, II; 181 Zav'yalka 1; 182 Bobrinka II; 183 Strelka I; 184 Malaya Lamna; 185 Volosovo; 186 Davydkovo; 187 Zhabki III; 188 Teren'kovo III; 189 Korenec I; 190 Seima I.

Sites of Valdaiskaya culture (with materials of Kotschischensky-type pottery): 141 Kotchishe 1,2; 142 Shepochnik; 143 Dubovec (Peno 3); 161 Zabel'e; 191 Zales'e I, II, Nizhnie Koticy 5, Zehnovo III, IV, Lanino I; 192 island Koshelev; 193 Zabolot'e II.

Sites in north-east Europe (sites of the type Dutovo I, Chernaya Vad'ya, chernoborskaya group, Kama culture sites located in the basin of the Sukhona River and Lake Onega): 144 Tudozero V; 145 Berezovaya slobodka II-III; 146 Prilukskaya; 147 Yavron'ga I; 148 Chernaya Vad'ya; 149 Chudgudor'yag, En'ty V; 150 Pezmog IV; 151 Seb'yag; 152 Ust'-Kulom I; 153 Kochmas B; 154 Niremka I, s.6; 155 group of Vis sites; 156 Dutovo I; 157 Chernoborskaya III; 158 Zubovo; 159 Koneshel'e; 160 Timoshel'e VI. 
* - dates made on materials from the excavation I of the site Rakushechny Yar.

** - materials from excavation of 2013 of the site Rakushechny Yar.

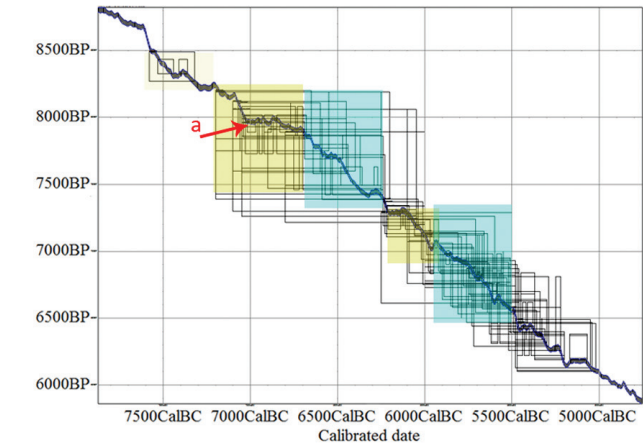
Calibrated da

$2 \quad$ Ki-14586 $6280 \pm 90 B P$ \begin{tabular}{|l|l|}
\hline Ki-14441 & $6290 \pm 90 B P$ \\
\hline Ki-14835 & $6310 \pm 90 B P$ \\
\hline
\end{tabular} Poz-42052 6380 \pm 40 BP Ki-14411 $6420 \pm 80 \mathrm{BP}$ Ki-14412 6470 $180 \mathrm{BP}$ Ki-14570 $6480 \pm 80 \mathrm{BP}$ Ki-14580 6540 $\pm 80 B P$ Ki-14117 6550 $\pm 130 \mathrm{BP}$ Ki-14464 6640 $\pm 100 \mathrm{BP}$ Ki-14113 6670 $\pm 100 B P$ Ki-14145 6680 $\pm 70 \mathrm{BP}$ Ki $145846700 \pm 100 \mathrm{BP}$ Poz-42053 6720 $\pm 40 \mathrm{BP}$ Ki-14078 6730 $\pm 100 \mathrm{BP}$ Ki-14111 6740 7 70BP Ki-14569 6760 $\pm 80 \mathrm{BP}$ Ki-14619 6760 $190 \mathrm{BP}$ Ki-14147 6770 $190 \mathrm{BP}$ Ki-14413 6820 $\pm 80 B P$ Ki $154396820 \pm 90 B P$ Ki-14096 6940 $\pm 90 \mathrm{BP}$ Poz-42054 6940 40 BP Ki-12168 6950ะ170BP KIA $39308 \quad 7018 \pm 45 B P$ Ki-6478 6930 $\pm 100 B P$ Ki-6479 6950 $\pm 100 B P$ Ki-6480 $7040 \pm 100 \mathrm{BP}$ Ua-48460 7554 169 BP Ua-48461 7010 $126 \mathrm{BP}$ Ua-41365 $6841 \pm 40 B P$ Ua-41364 7156 4 41BP Poz $47870 \quad 7160 \pm 40$ BP AA 96017 7222 \pm 58 BP

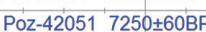
$\mathrm{SPb}-5877560 \pm 70 \mathrm{BP}$ $\mathrm{SPb}-4247660 \pm 200 \mathrm{BP}$ Ki-14567 7680+90BP Ki-12167 $7680 \pm 190 \mathrm{BP}$

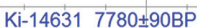
$\mathrm{SPb}-4267790 \pm 200 \mathrm{BP}$ Ki-12166 $7810 \pm 190 \mathrm{BP}$ Ki-14568 7930 $\pm 90 \mathrm{BP}$ Ua-37097 $7290 \pm 50 \mathrm{BP}$ Ki-6475 $7690 \pm 110 \mathrm{BP}$

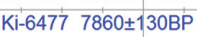
Ki--6476 $7930 \pm 40 B P$ $\mathrm{SPb}-7297970 \pm 110 \mathrm{BP}$ Lé $23438020 \pm 90 \mathrm{BP}$ Ua-37099 $8380 \pm 55 \mathrm{BP}$ Calibrated date $9000 \mathrm{CalBC}$

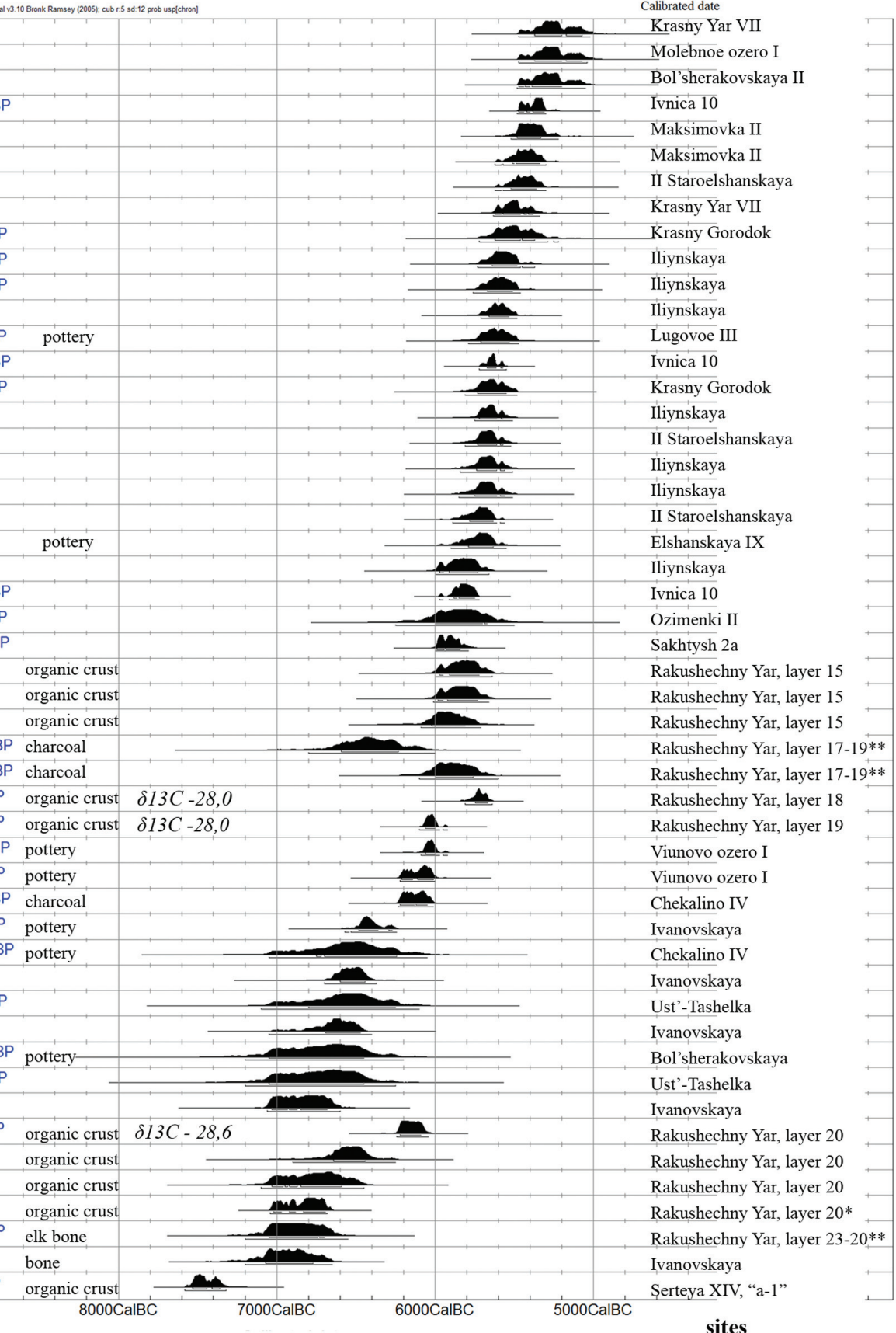
dating material (if known)

sites

Fig. 4. Histogram (1) and a list of calibrated values (2) (made in OxCal 3.10 (Bronk Ramsey 2005) of radiocarbon dates of sites with undecorated pottery (dates of figures 2, 4, 5 - after Vybornov 2008; Vybornov et al. 2008; 2012; 2013; Ivanisheva 2009; Hartz et al. 2012; Smol'yaninov, Surkov 2014; Tovkailo 2010; Gaskevich 2010; Karmanov 2008; Zaiceva et al. 2014; Tsybriy et al. 2014) and indication of a 'calibration plateau' 8000-7500 BP (1a). 
2

BP

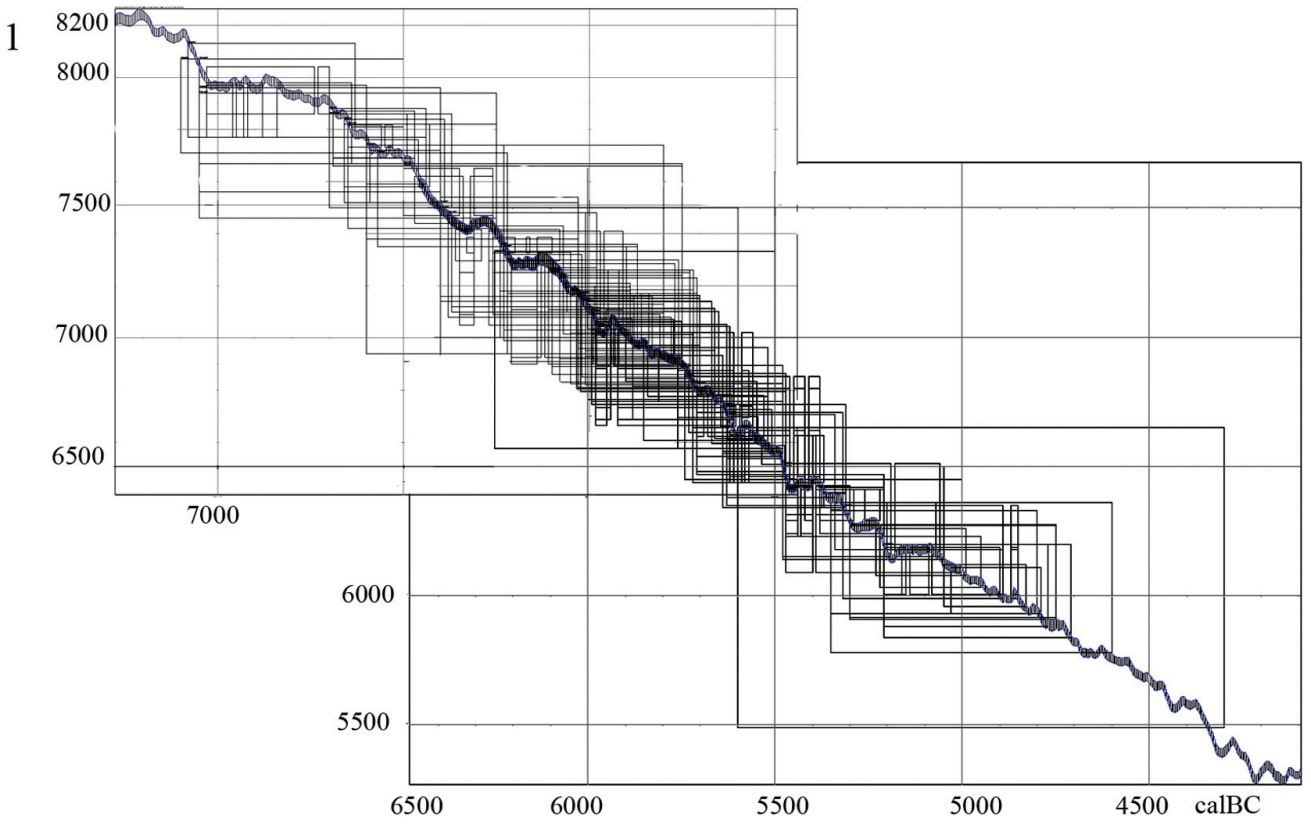

Atmospheric data from Reimer et al (2004); OxCal V3. 10 Bronk Ramsey (2005); cub r.5 sd: 12 prob usp[chron]

$\mathrm{Ki}-141107080 \pm 80 \mathrm{BP}$ SPb - $4257100 \pm 200 \mathrm{BP}$

Ki-14372 $7100 \pm 80 \mathrm{BP}$

Ki - $144407105 \pm 90 \mathrm{BP}$

$\mathrm{Ki}-141447120 \pm 90 \mathrm{BP}$

Ua-37098 $7150 \pm 50 \mathrm{BP}$

$\mathrm{Ki}-141437170 \pm 90 \mathrm{BP}$

$\mathrm{Ki}-141327180 \pm 90 \mathrm{BP}$

Ki-14633 $7190 \pm 80 \mathrm{BP}$

$\mathrm{Ki}-140947230 \pm 90 \mathrm{BP}$

Ki-14368 $7230 \pm 90 \mathrm{BP}$

$\mathrm{Ki}-141097250 \pm 80 \mathrm{BP}$

Ki-14374 7280 $\pm 100 \mathrm{BP}$

Ki $16400 \quad 7290 \pm 190 \mathrm{BP}$

Le-5260 $7300 \pm 180 B P$

Le-6713 7340士200BP

Le-6707 7340 $190 \mathrm{BP}$

KIA' $393107356 \pm 30 B P$

Ki-14632 7530 $190 \mathrm{BP}$

$\mathrm{Ki}-145007560 \pm 90 \mathrm{BP}$

Ki - $141427620 \pm 100 \mathrm{BP}$

$\mathrm{Ki}-145017680 \pm 80 \mathrm{BP}$

$\mathrm{Ki}-140967680 \pm 90 \mathrm{BP}$

SPb - $3777700 \pm 120 \mathrm{BP}$

Ki - $140957740 \pm 70 \mathrm{BP}$

$\mathrm{Ki}-141087760 \pm 100 \mathrm{BP}$

Ua - $413597775 \pm 42 \mathrm{BP}$

Ki - $144717780 \pm 90 \mathrm{BP}$

Ki $164017870 \pm 100 B P$

Ua-37100 $7870 \pm 100 \mathrm{BP}$

Ki-14097 7890 $190 \mathrm{BP}$

$\mathrm{Ki}-140977890 \pm 90 \mathrm{BP}$

Ki - $141337950 \pm 90 B P$

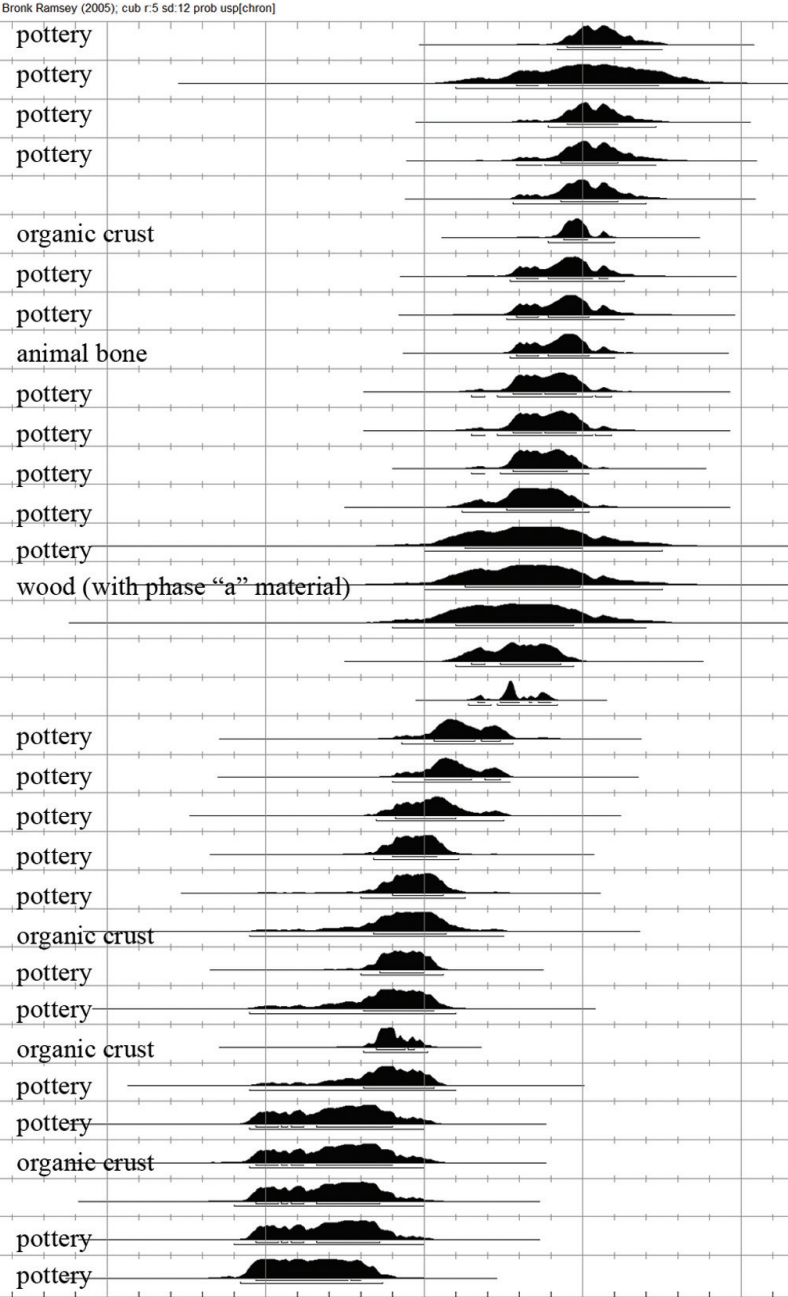

Varfolomeevka, layer 3

Kairshak I

Varfolomeevka 2A

Kairshak IV

Varfolomeevka, layer 3

Serteya X, phase "a"

Varfolomeevka, layer 3

Kairshak I

Kairshak III

Kairshak I

Varfolomeevka, layer 2B

Varfolomeevka, layer 3

Varfolomeevka, layer 2B

Kairshak III

Rudnya Serteyskaya, phase "a"

Berezovaya slobodka II-III

Berezovaya slobodka II-III

Sakhtysh 2a

Kairshak III

Kugat IV

Varfolomeevka, layer 3

Kugat IV

Kairshak III

Kairshak III

Kairshak III

Varfolomeevka, layer 3

Kairshak III

Kairshak III

Kairshak III

Rudnya Serteyskaya, phase "a"

Kyzylhak

Kairshak III

Kairshak III

$8500 \mathrm{CalBC} \quad 8000 \mathrm{CalBC}$

7500 CalBC

$7000 \mathrm{CalBC}$

$500 \mathrm{CalBC} \quad 6000 \mathrm{CalBC} \quad 5500 \mathrm{CalBC}$

5000 CalBC 


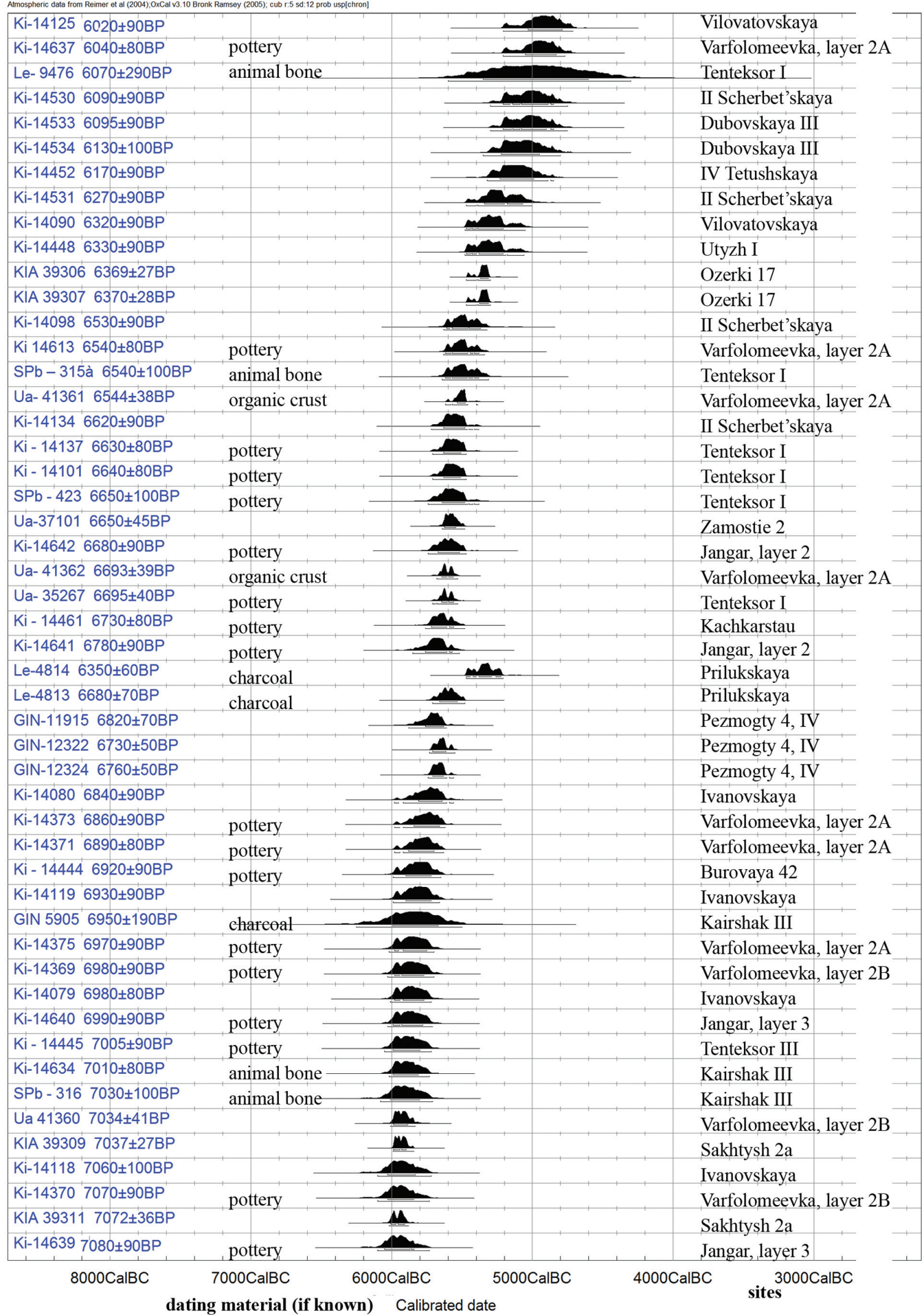

Fig. 5. Histogram (1) and calibrated values (2) of radiocarbon dates (made in OxCal 3.10 (Bronk Ramsey 2005) from sites with pottery decorated by triangular impressions, drawn and oval impressions. 


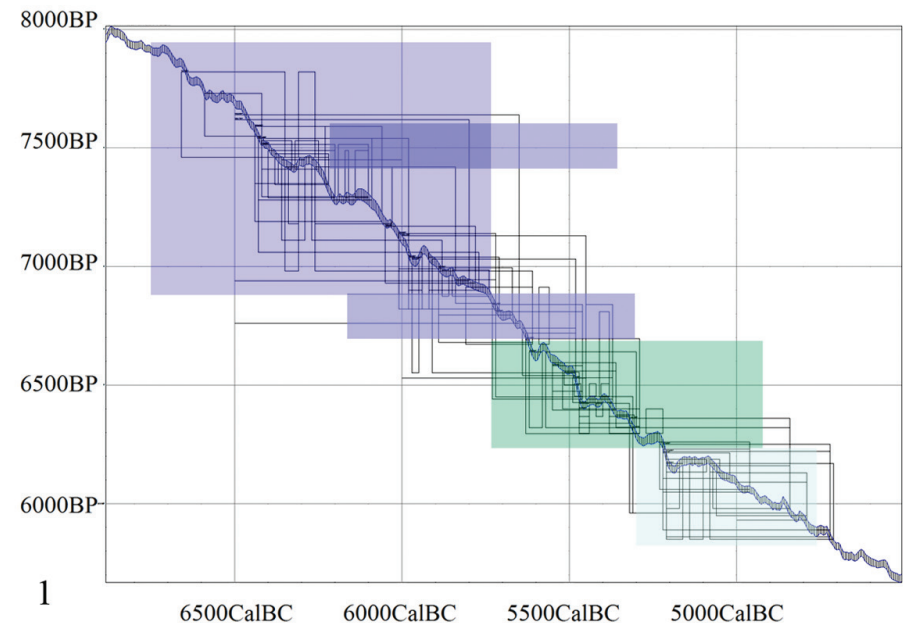

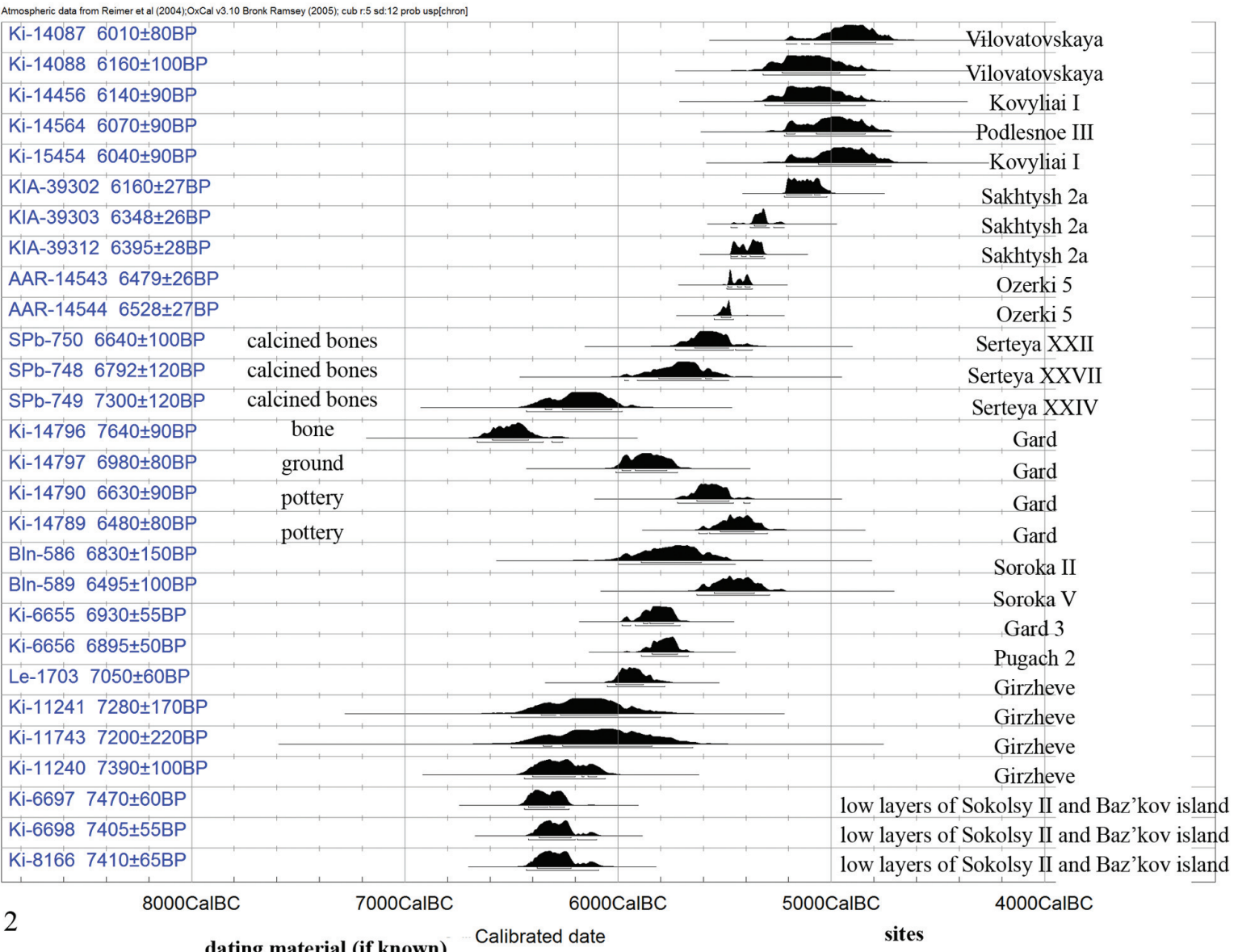

Fig. 6. Histogram (1) and calibrated values (2) of radiocarbon dates (made in OxCal 3.10 (Bronk Ramsey 2005) from sites with pottery decorated with impressions made by various comb-tools. 


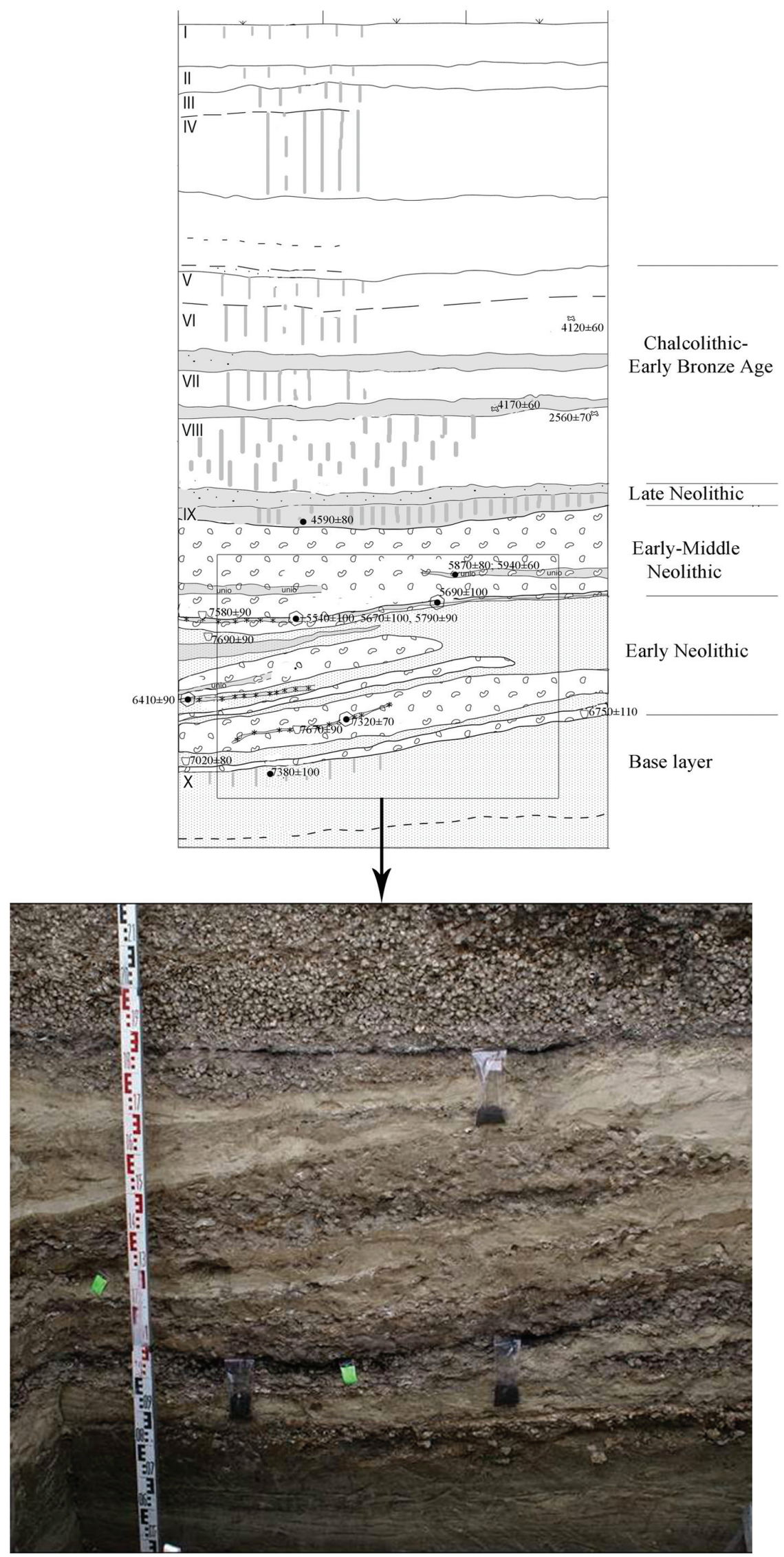

Fig. 7. Stratigraphy of the 2008 test-pit (after Aleksandrovsky et al. 2009.Fig. 3) with date distributions in the layers, and photograph of the low part of the 2008 test-pit (photo: A. Mazurkevich). 

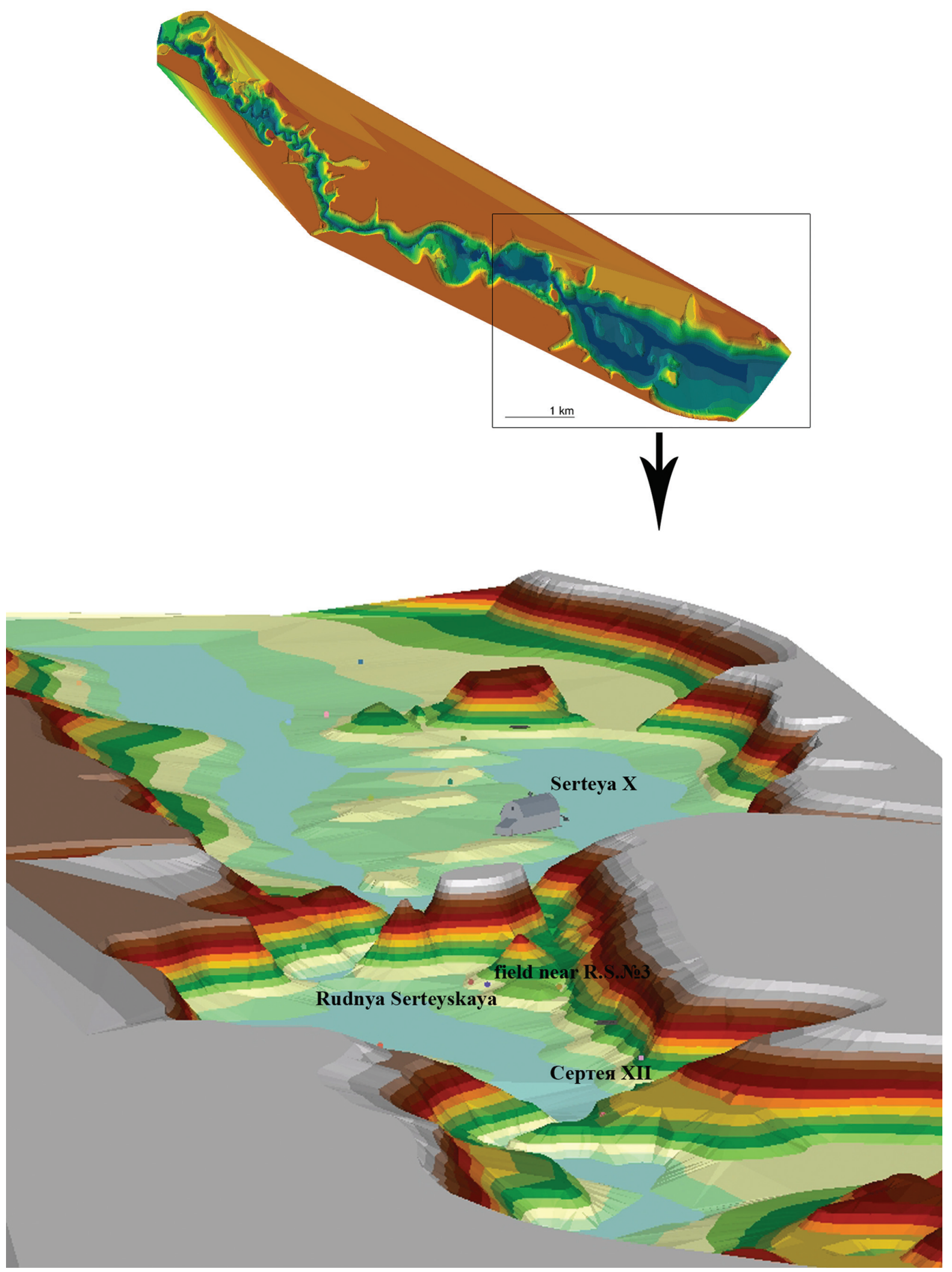

Fig. 8. Early Neolithic sites' distribution in the southern part of Serteysky microregion. 

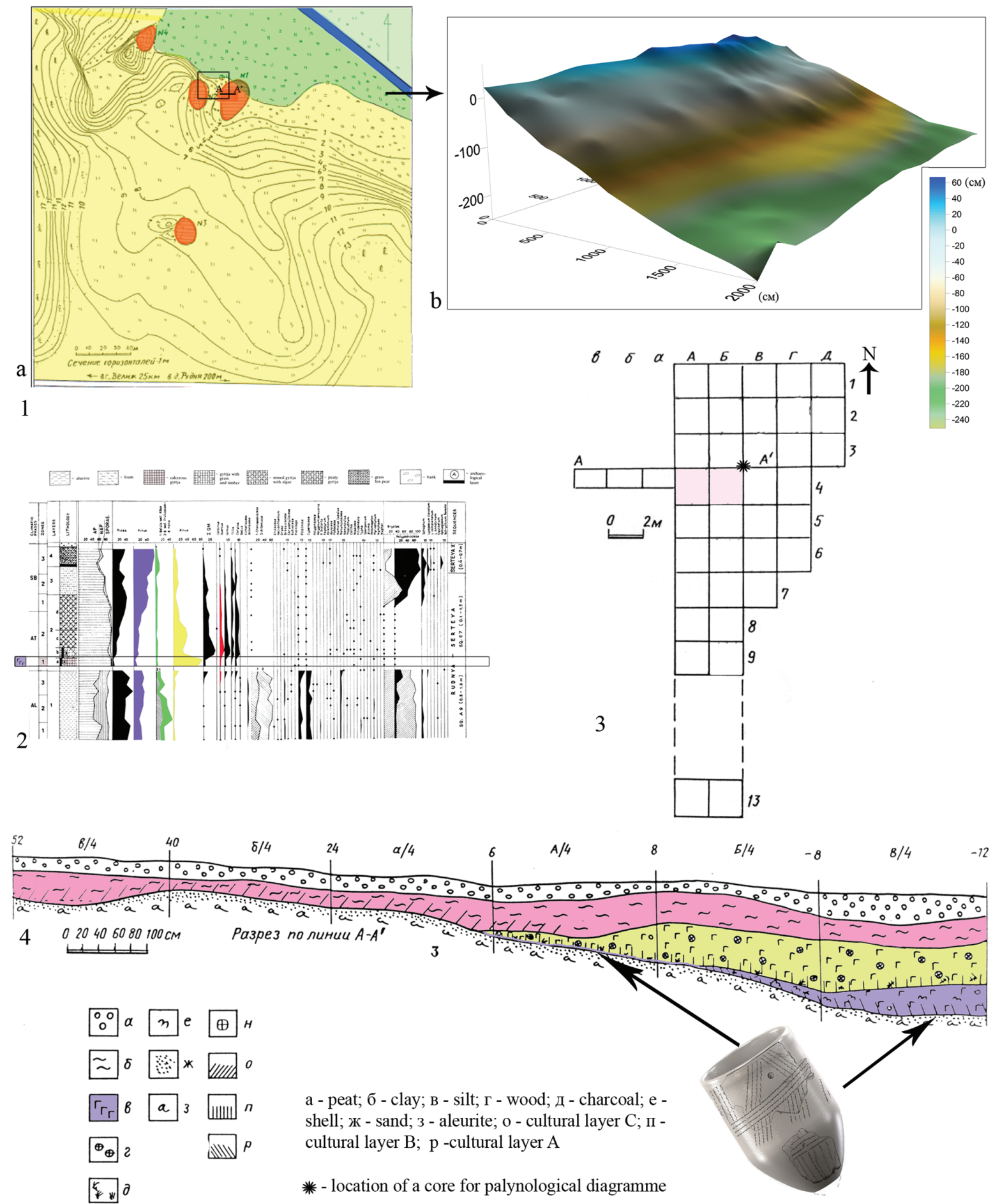

Fig. 9. Rudnya Serteyskaya. 1a location of the site and field near Rudnya Serteyskaya 2-4 in the DneprDvina region (after Mazurkvich, Miklyaev 1998.Fig. 2,1 ); 1 b relief reconstruction; 3 plan of the excavated part with indication of position of phase 'a' vessels; 2 stratigraphy with indication of vessel fragments of phase 'a' position and palynological diagram with indication of layer that covered the layer containing Early Neolithic pottery (after Dolukhanov et al. 1989.Fig. 1). 

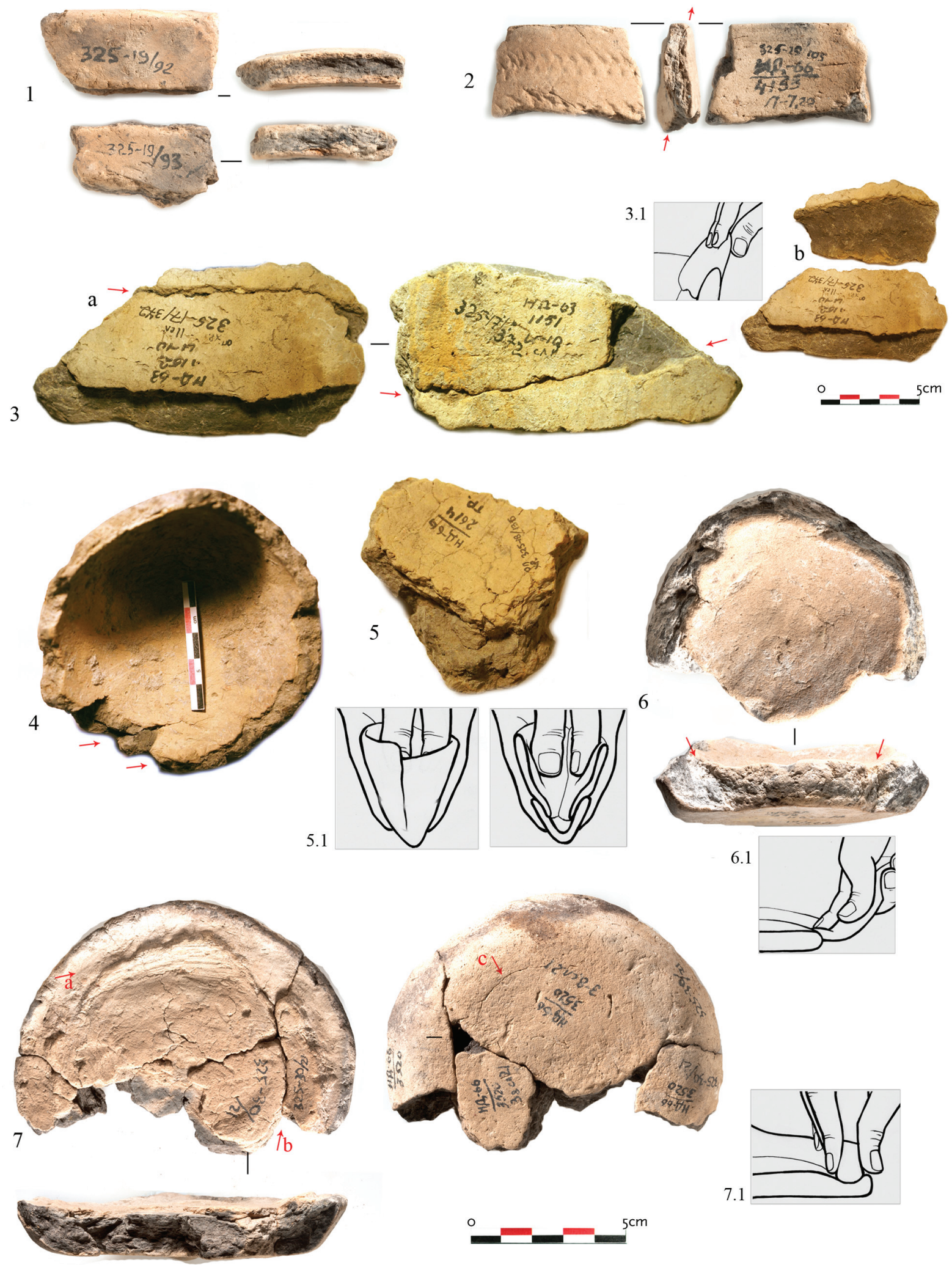

Tab. 1. Rakushechny Yar. Macro-traces on vessel surfaces. 1 U-junction of coils; $2 \mathrm{~N}$-junction with slight stretching; 3a junction of coils greatly stretched, $3 b$ part of the coils (3.1 reconstruction of vessel modelling); 4 traces of coils and modelling of the walls on a conical base; 5 traces of slabs joining conical bases (5.1 reconstructed modelling of conical base); 6 places where coils join while the flat base was modelled with coils (6.1 reconstruction); 7 'groove' left on the perimeter of the flat base (a), fractures left where coils were joined (b), curved fracture, which marks the junction of coils (c) (7.1 reconstructed base). 

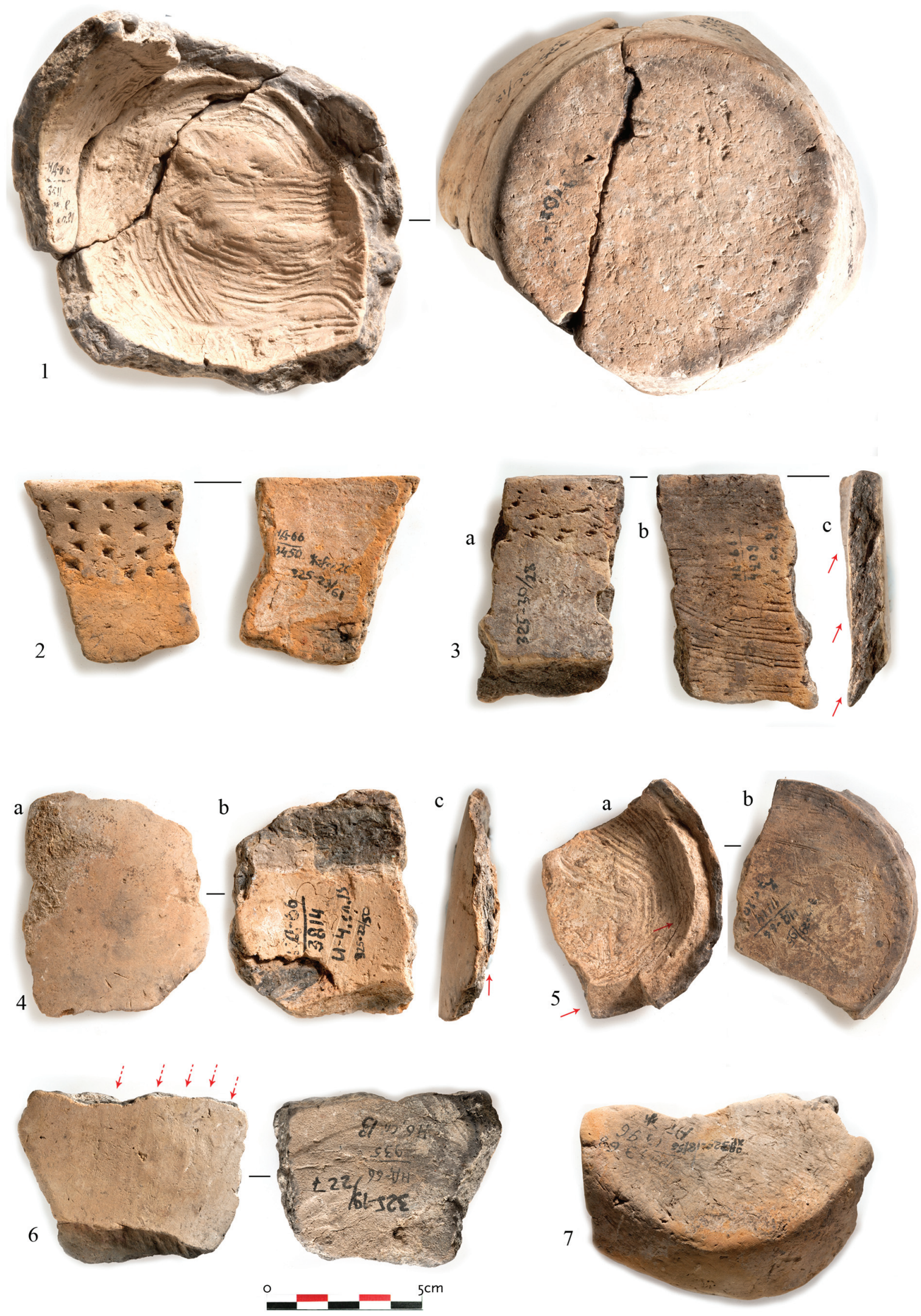

Tab. 2. Rakushechny Yar. Macro-traces on vessel surfaces. 1 traces left by a comb-like tool on the inner side of the base; $2,3 a, 4 a, b, 5 b$ smoothed surface; $3 b$ traces left after inner surface treatment; $3 c$ oblique direction of coils' in profile; 4 b two slabs/fragments of coils; $4 \mathrm{c}$ vertical fracture marking two slabs/coils; 5 a coils on flat base; 6 traces left after smoothing with pebble; 7 imprint on outer side of flat base. 

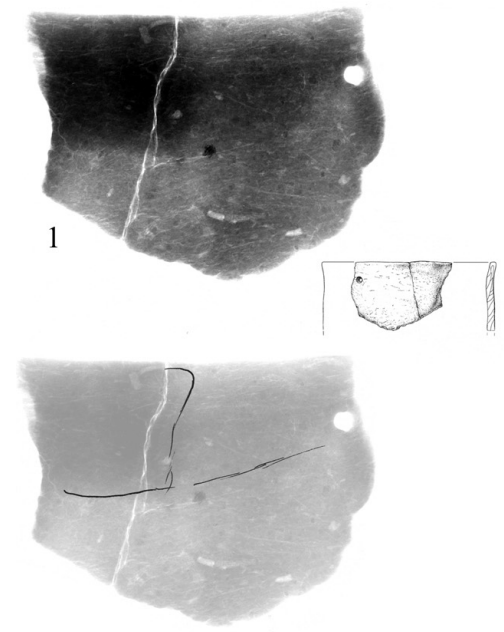
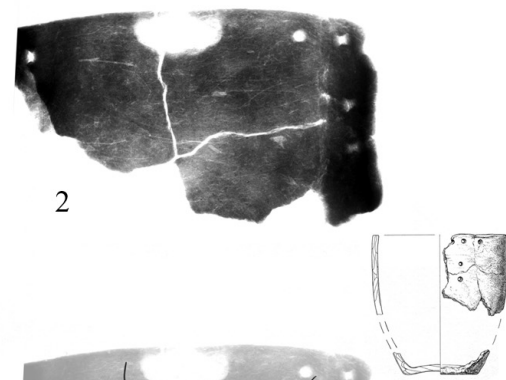

3

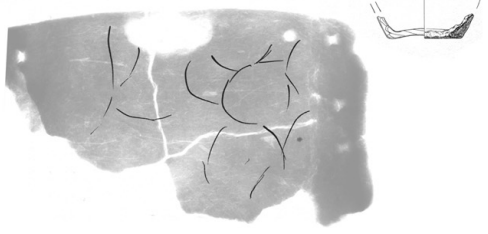

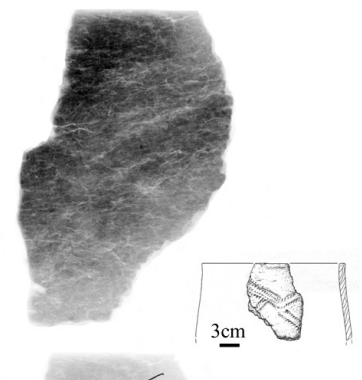

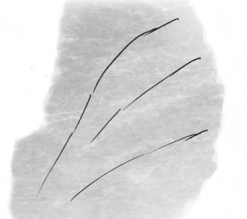

Tab. 3. Rakushechny Yar. Radiography of the vessel fragments, with indication of different technological traces.
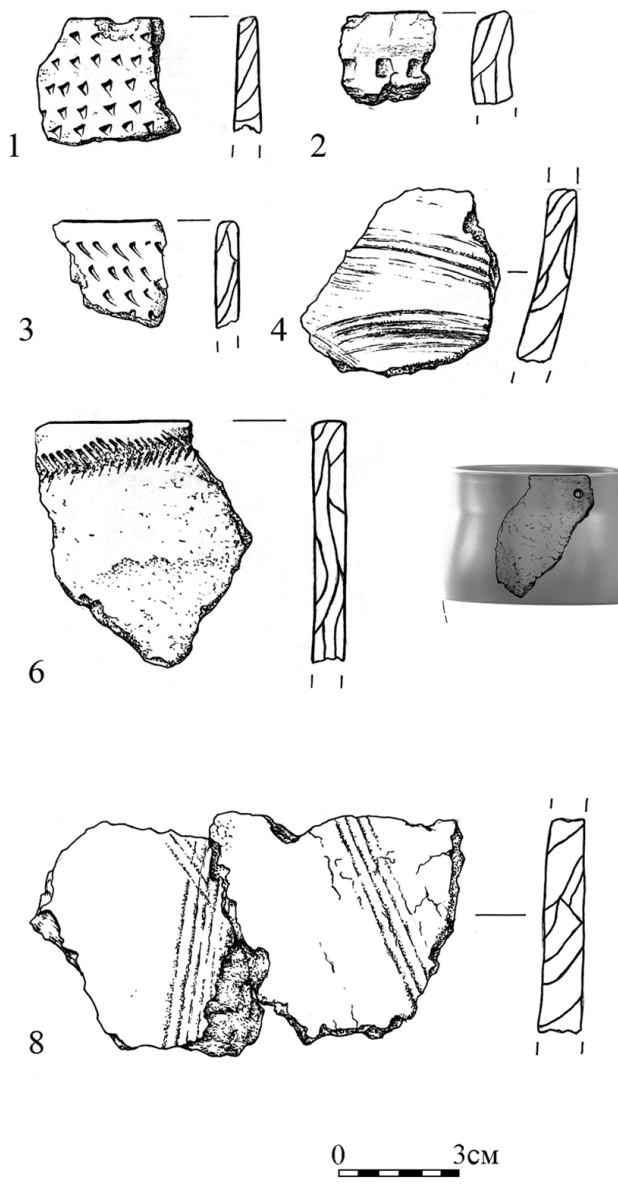

11

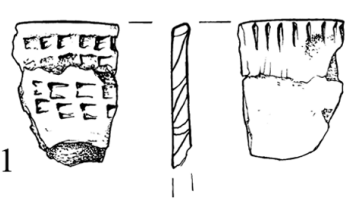

12

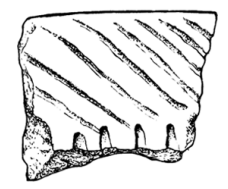

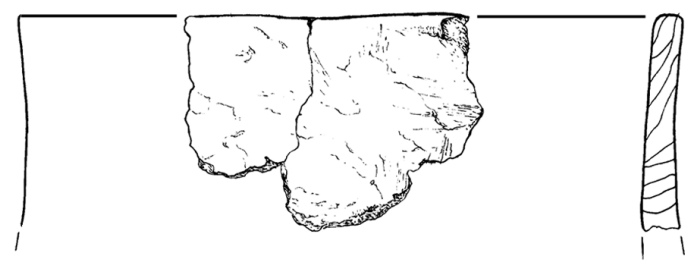
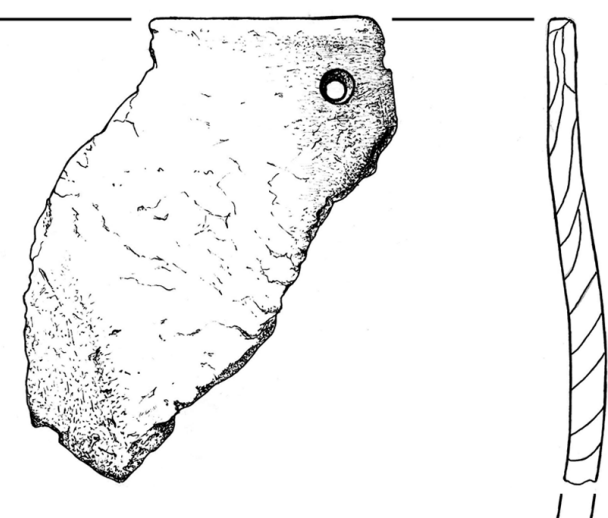

9
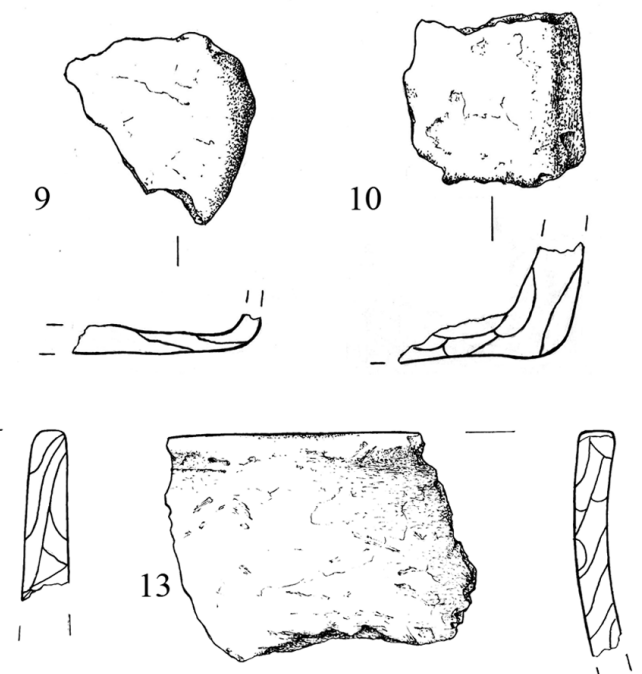

Tab. 4. Rakushechny Yar. Pottery. 1-10 layer 23; 11-13 layer 22. 

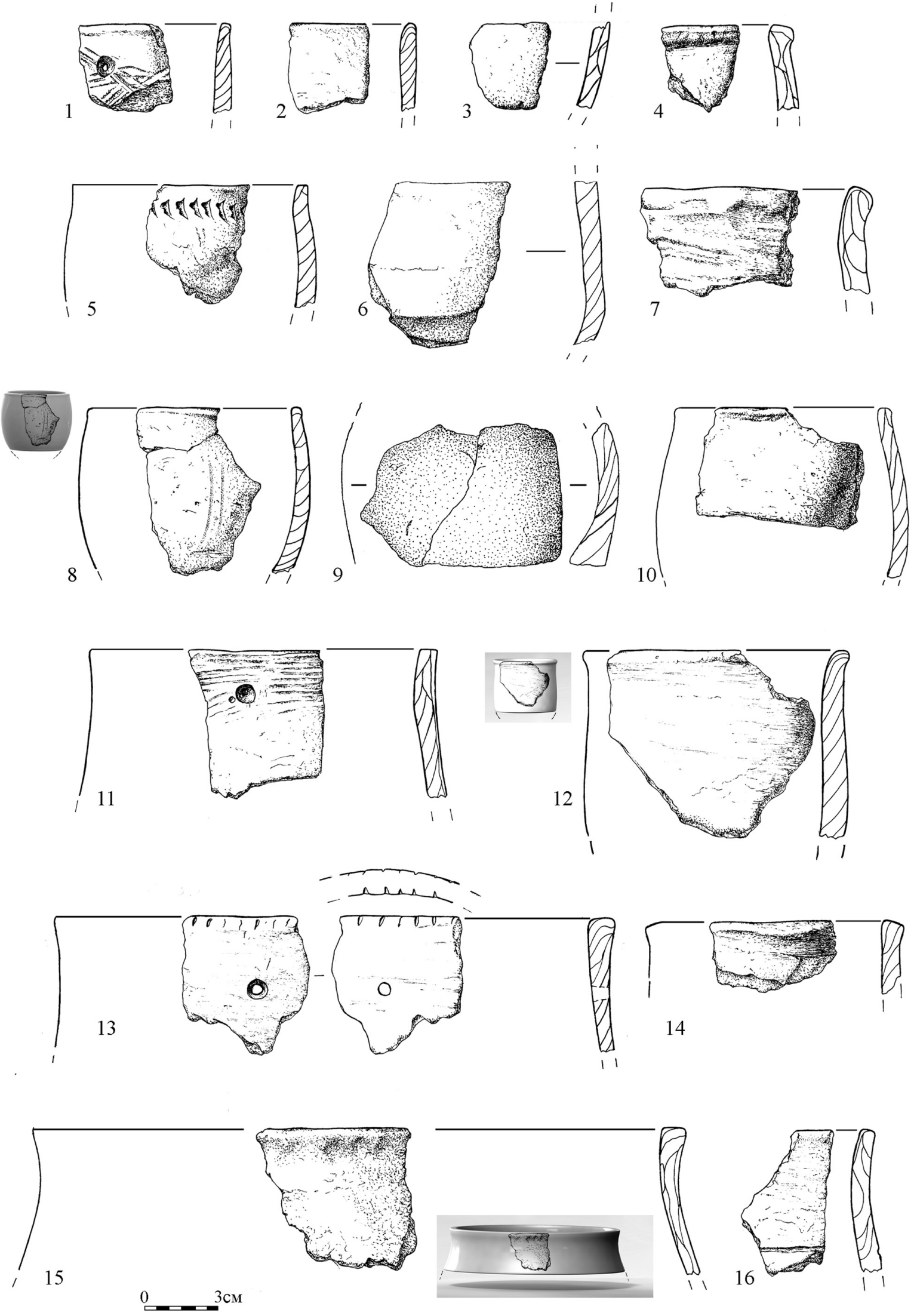

Tab. 5. Rakushechny Yar. Pottery from layer 20. 

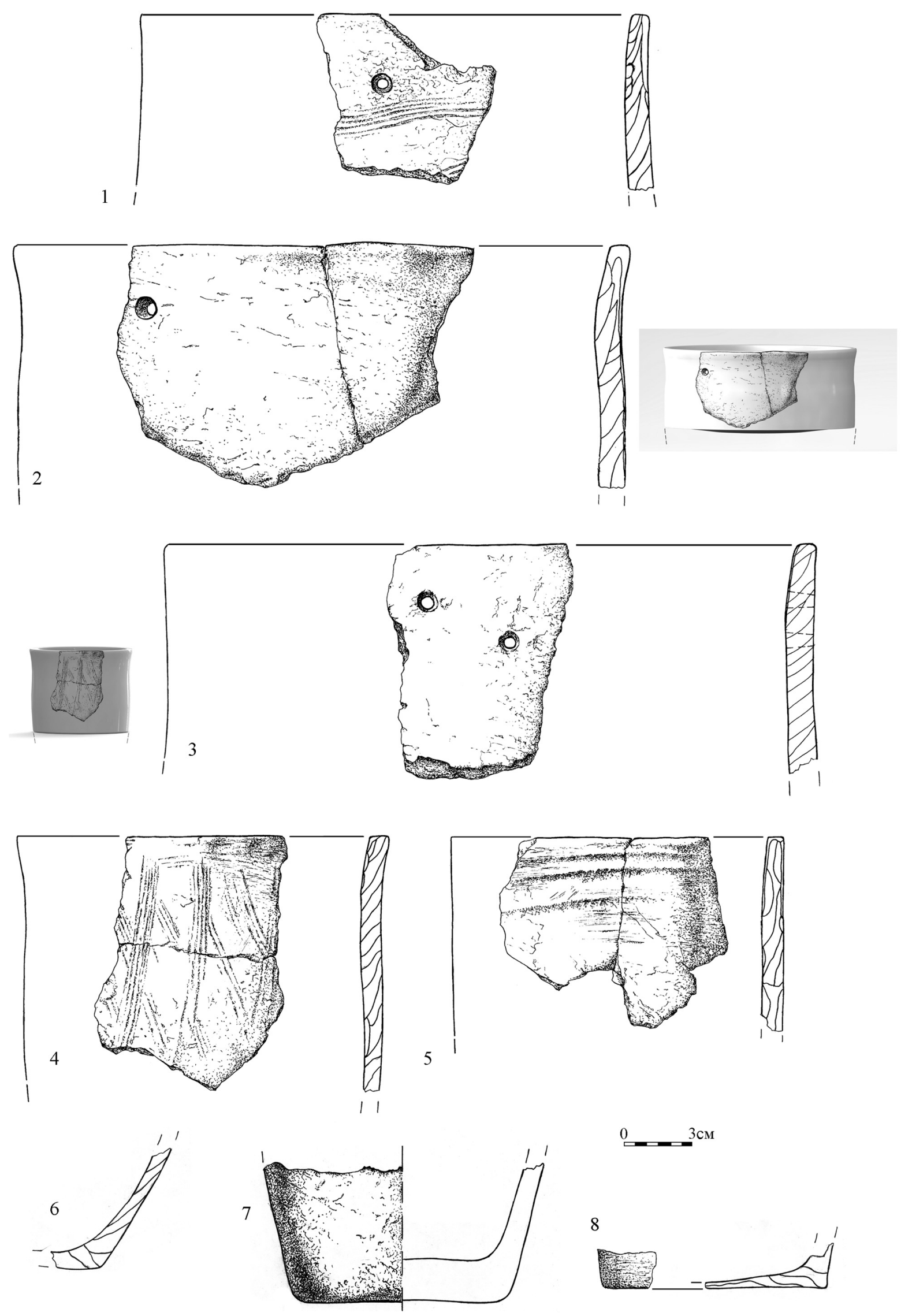

Tab. 6. Rakushechny Yar. Pottery from layer 20. 

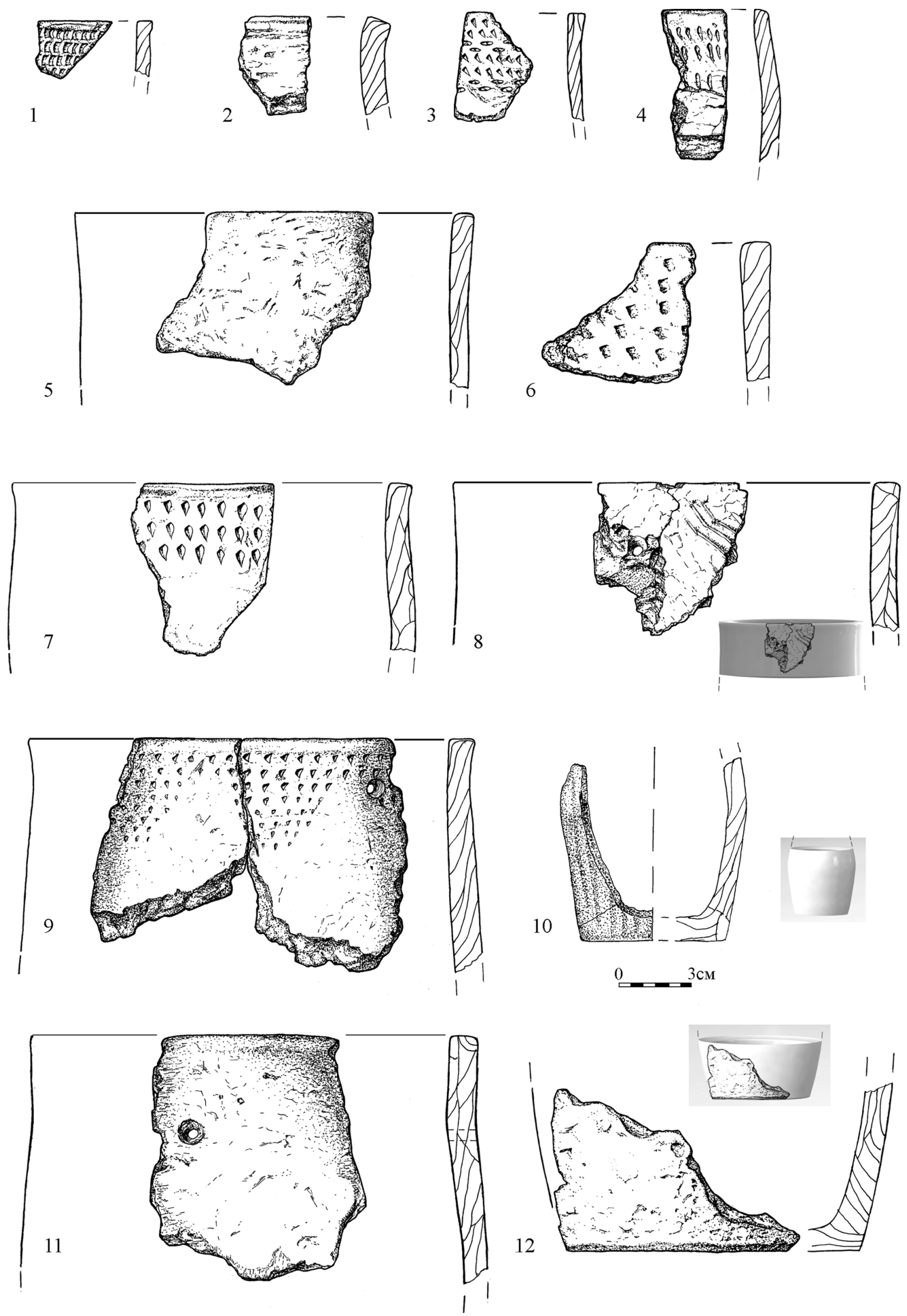

Tab. 7. Rakushechny Yar. Pottery from layer 19. 

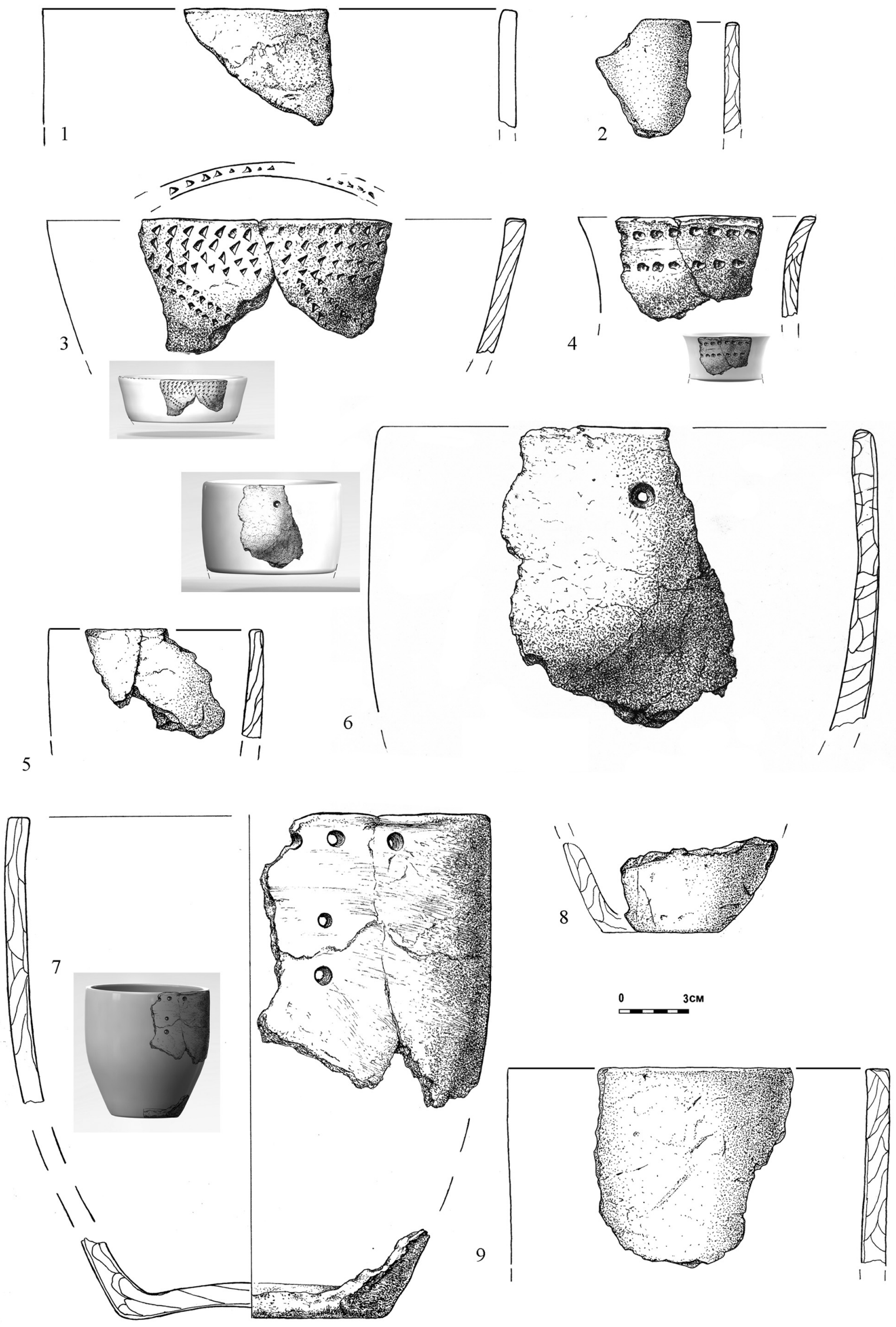

Tab. 8. Rakushechny Yar. 1-6, 8-9 pottery from layer 14; 7 reconstructed vessel from layer 15. 

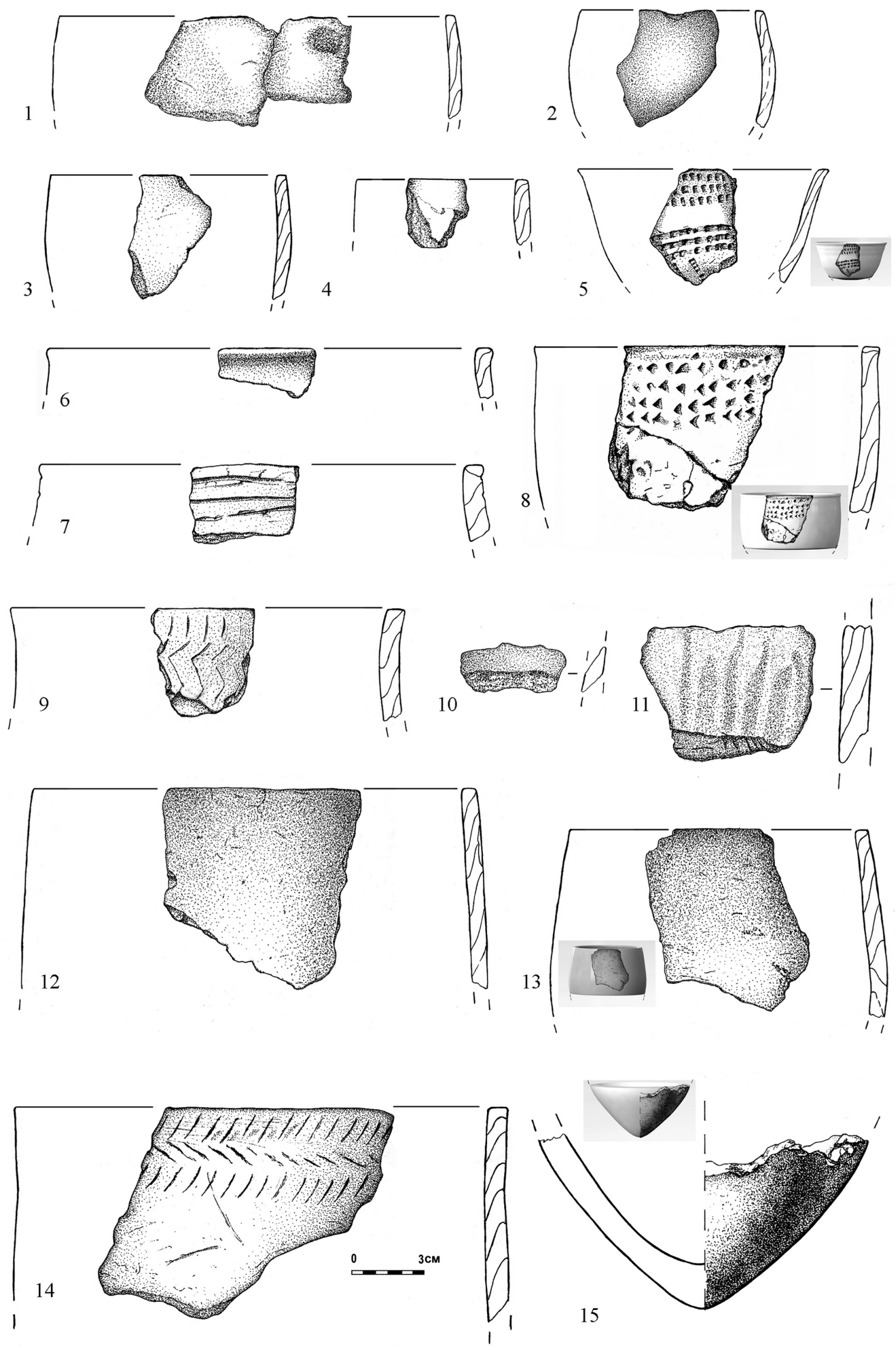

Tab. 9. Rakushechny Yar. Pottery from layer 13. 

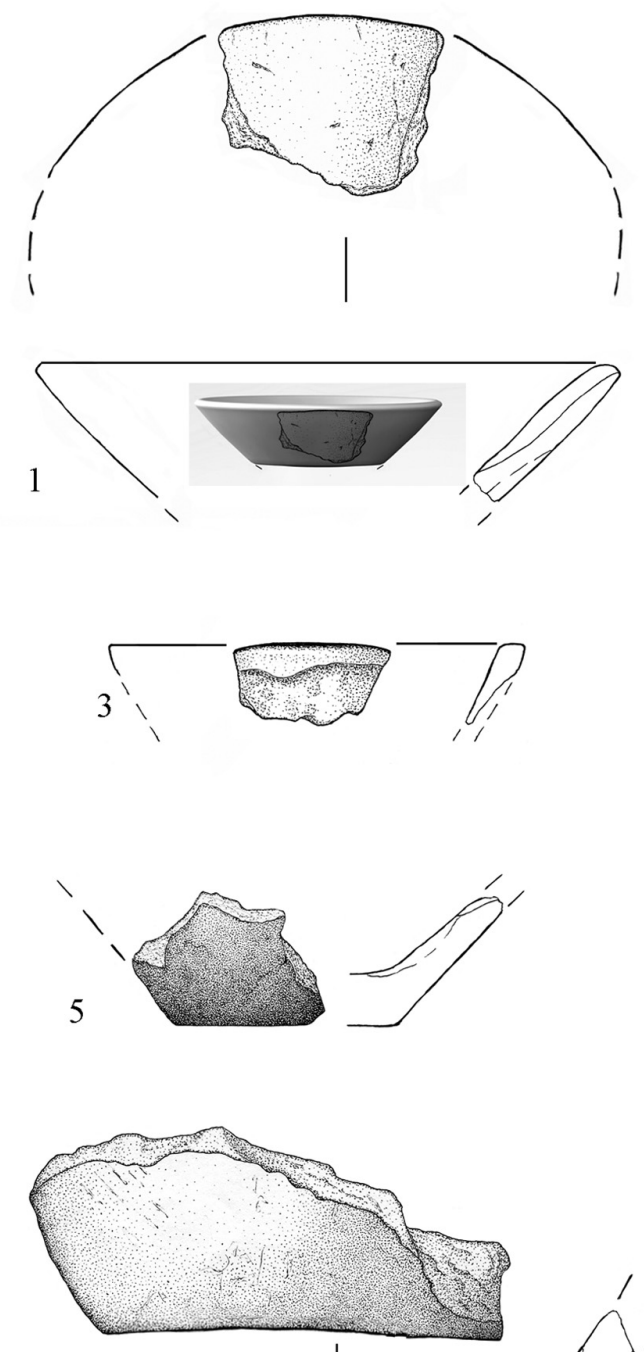

61

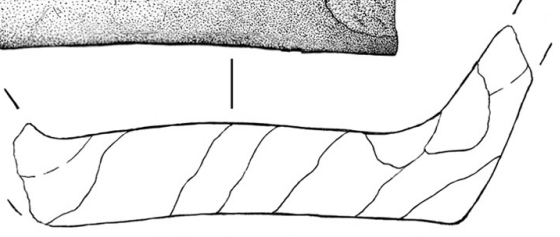

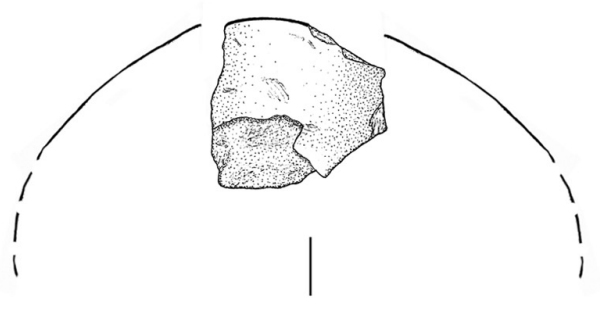
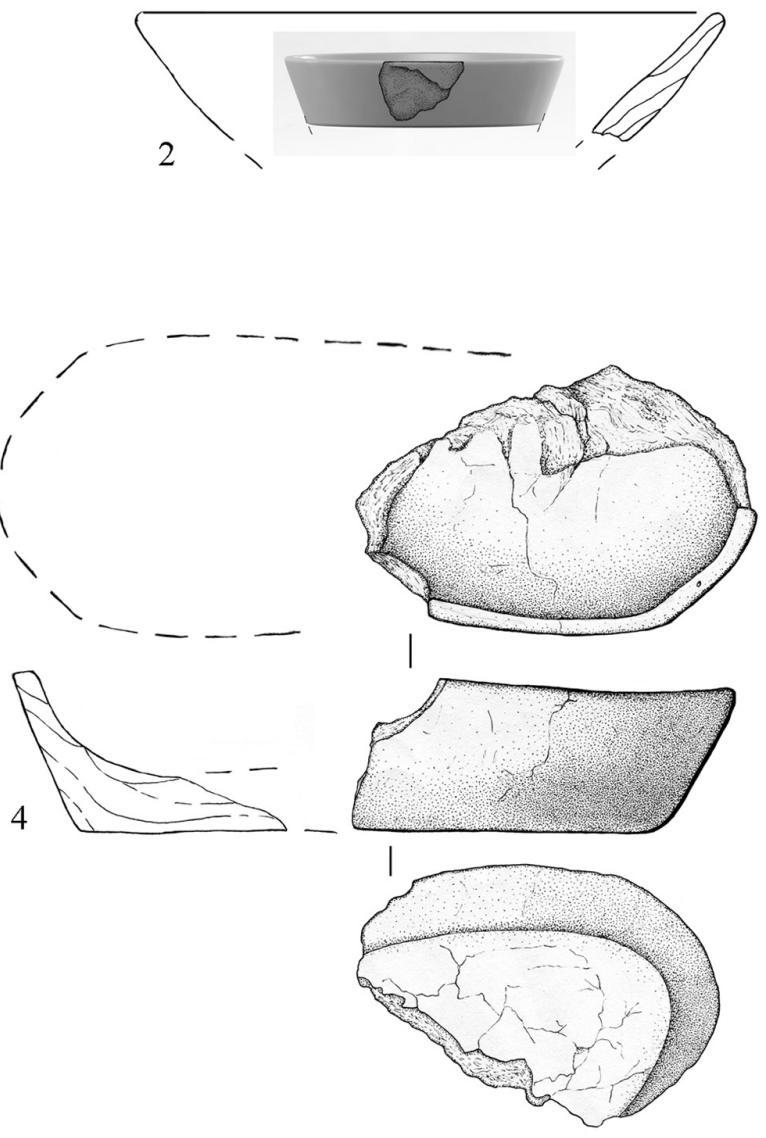

8
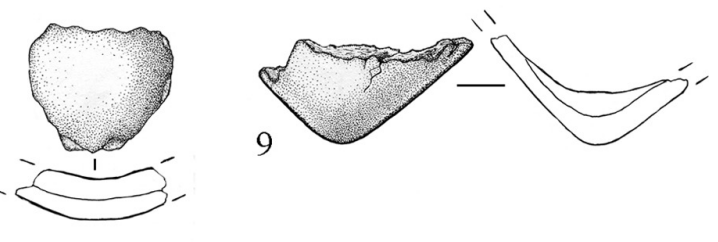

10
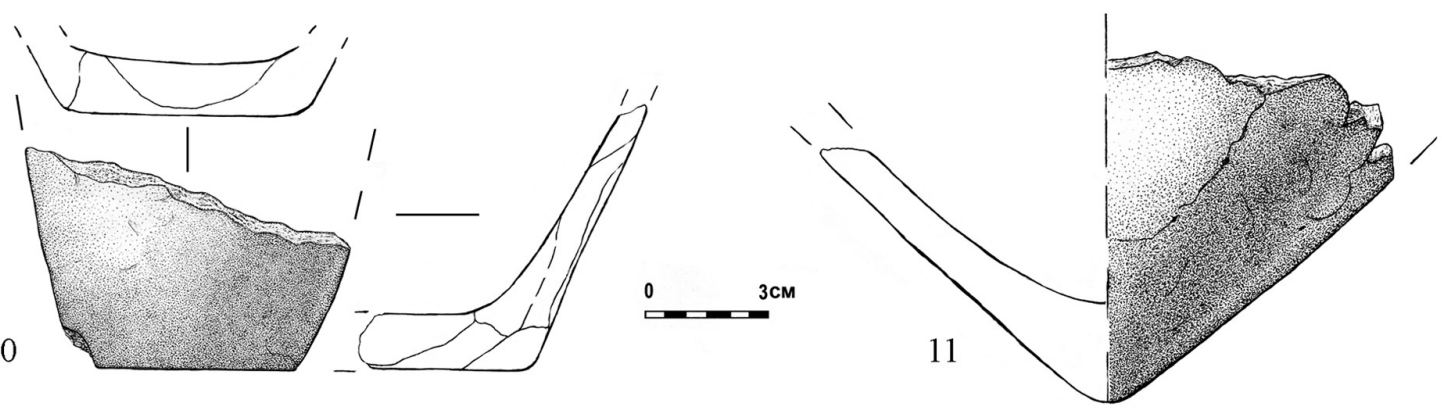

Tab. 10. Rakushechny Yar. Pottery from layer 11. 

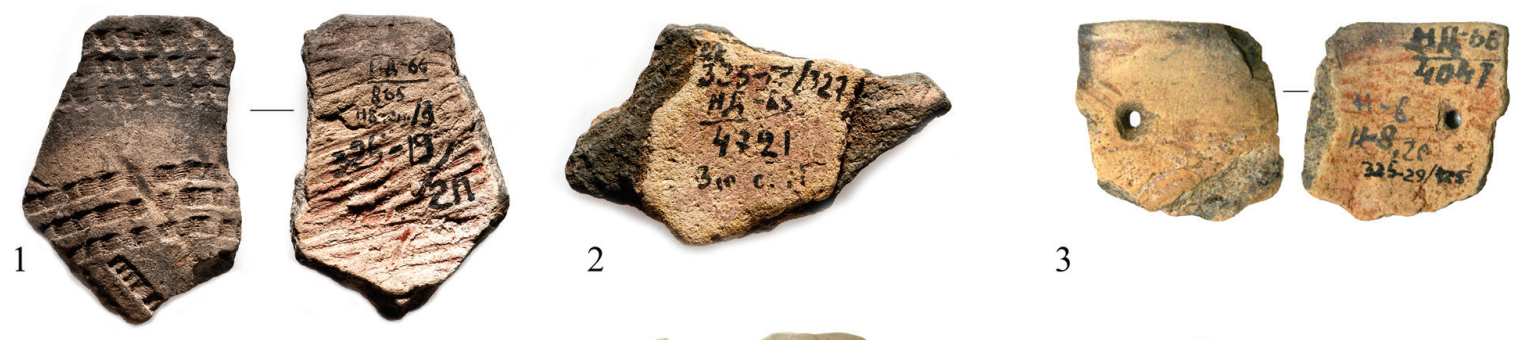

3
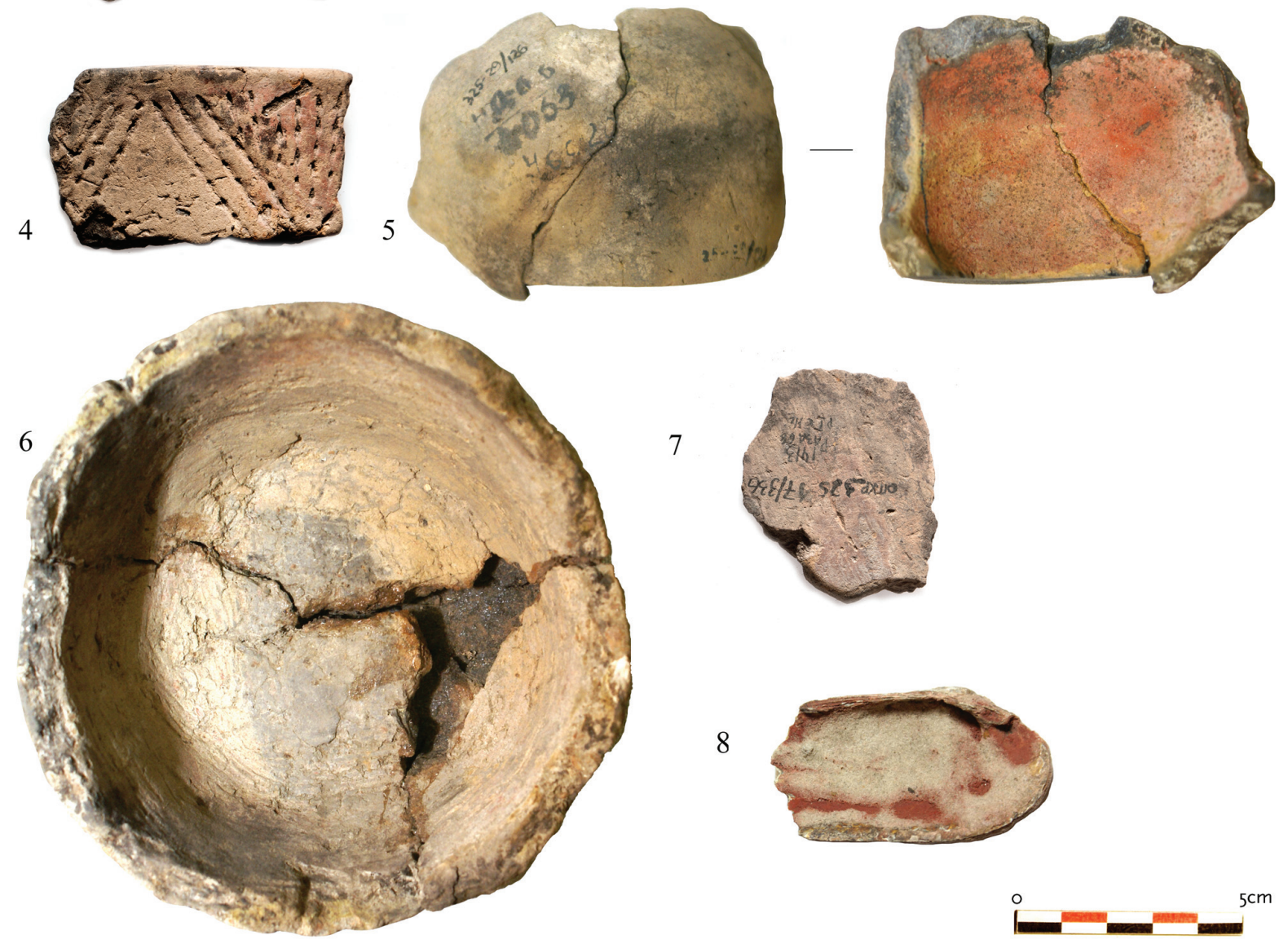

Tab. 11. Rakushechny Yar. Vessels covered with ochre (1 - layer 13; 2, 4, 7-layer 11; 3, 5-6, 7 - layer 20) and Unio shell with ochre (8). 


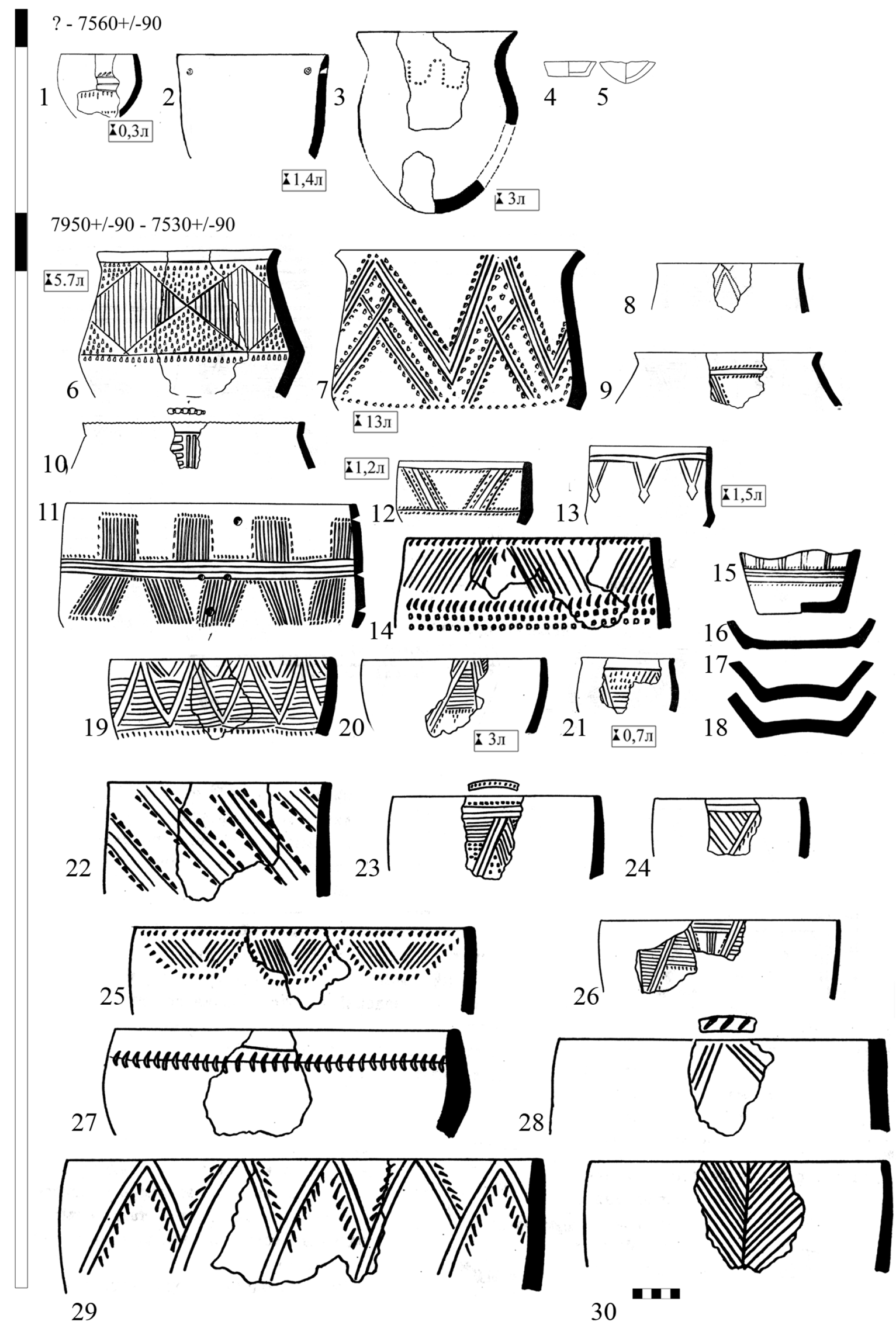

Tab. 12. Pottery of Low Volga basin. 1-2 Kugat IV; 3 Kulagaisi; 4-5 Tu-Buzgu-Huduk I; 6-30 Kairshak III (1-3 after Vybornov 2008.Fig. 3; 4-5 after Vybornov 2008.Fig. 23; 6-30 after Vasiliev et al. 1989.Fig. 2-6). 

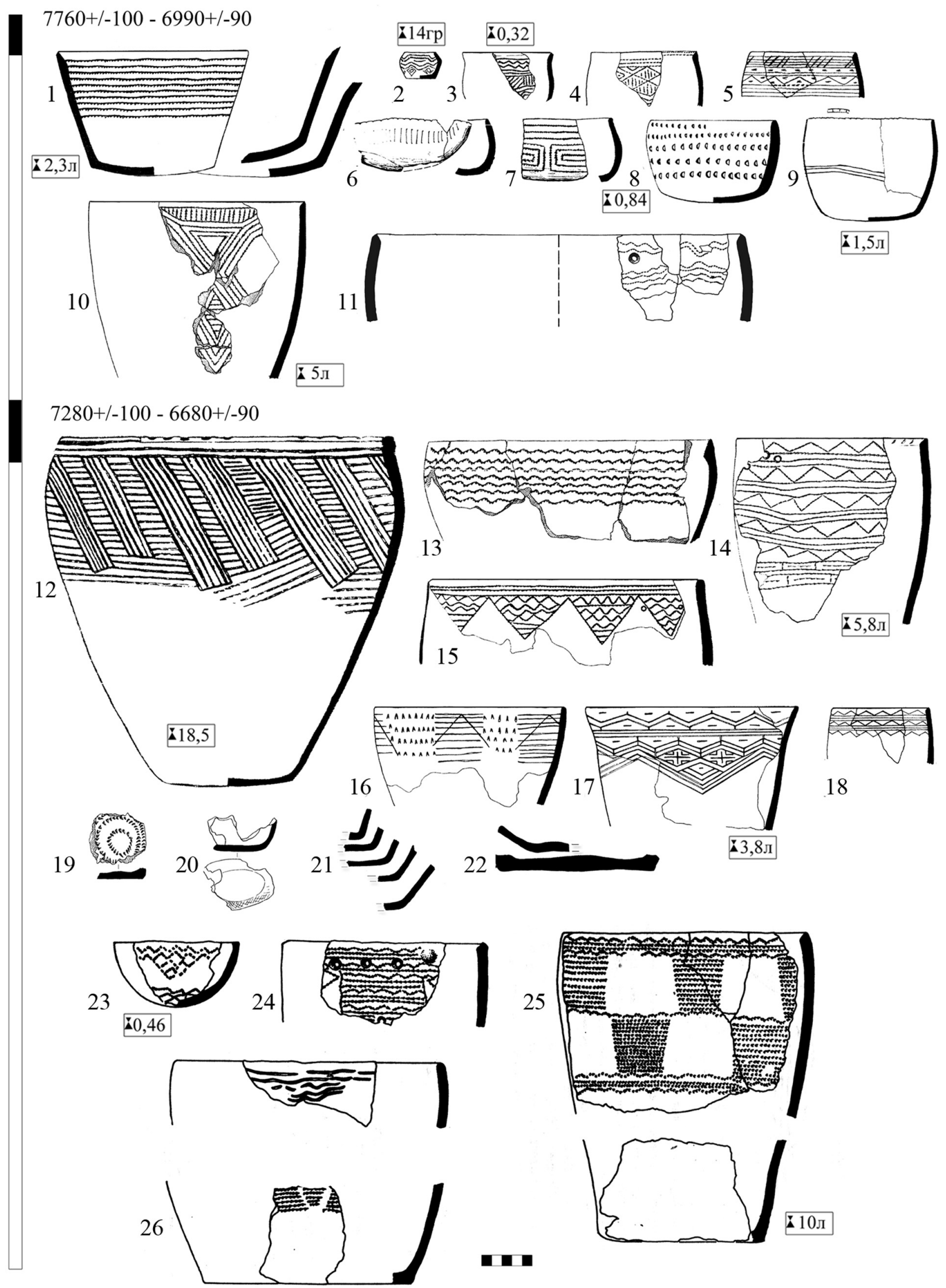

Tab. 13. Pottery of Low Volga basin. 1-10 Varfolomeevka, layer 3; 11 Jangar, layer 3; 12-22 Varfolomeevka, layer 2B; 23-26 Jangar, layer 2 (1-2, 6-7, 9 after Yudin 2004.Fig. 8; 3-5, 8, 10 after Yudin 2004. Fig. 12; 11 after Kolcov 1988.Fig. 15; 23-26 after Kolcov 1988.Fig. 12). 
$7930+/-90-7680+/-90$
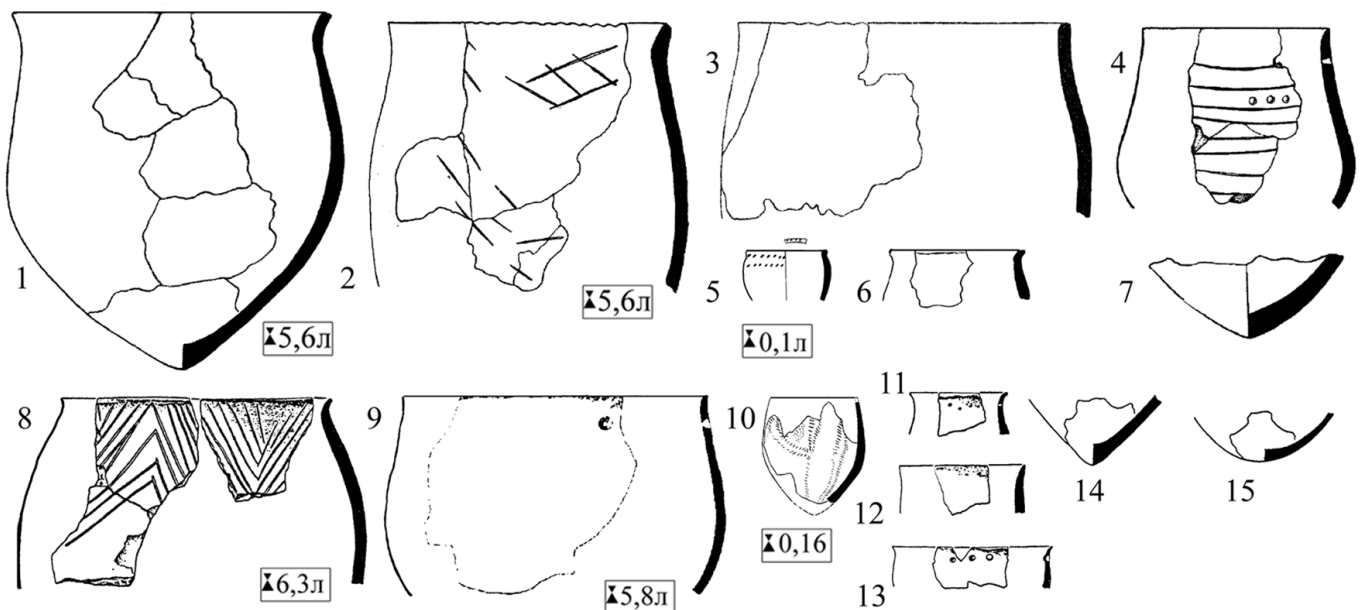

\section{$0,1 \pi$}

7

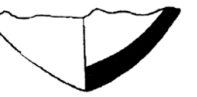

$10 \sqrt{4}$

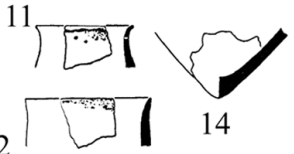

15

$\triangle 0,16$

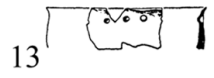

$7250+/-60-6940+/-90$

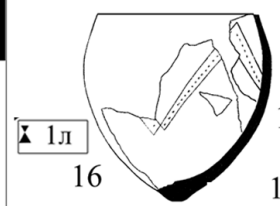

17

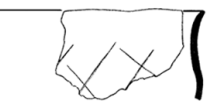

18

19

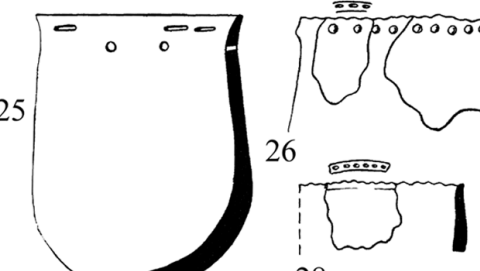

28

29
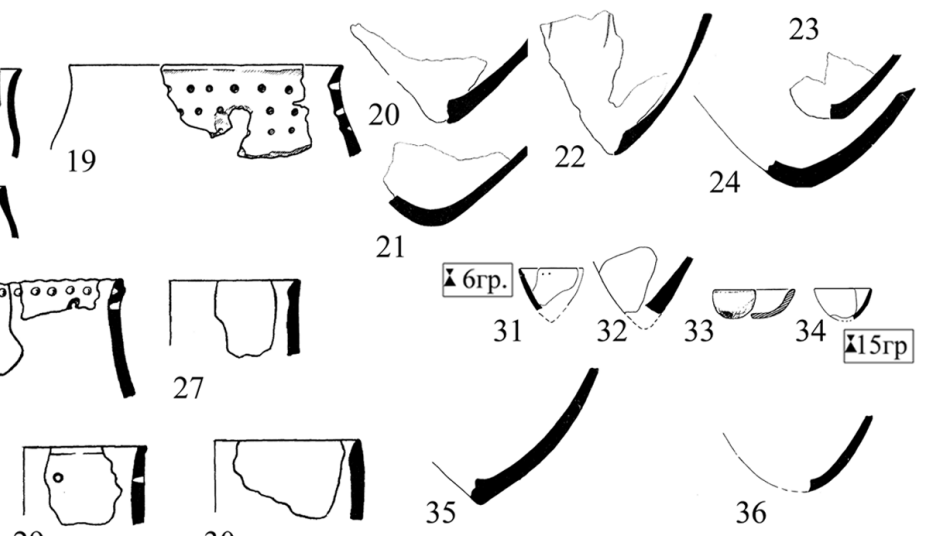

21

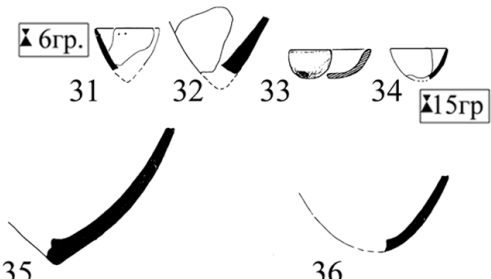

30

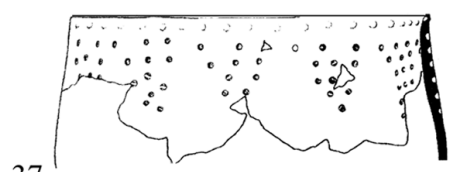

37
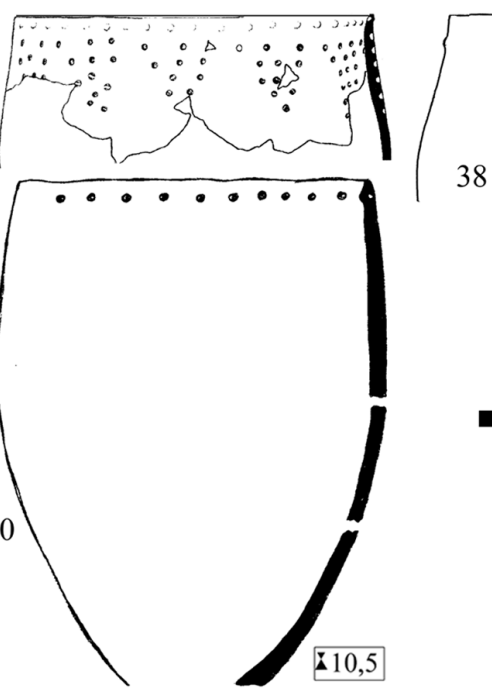

38
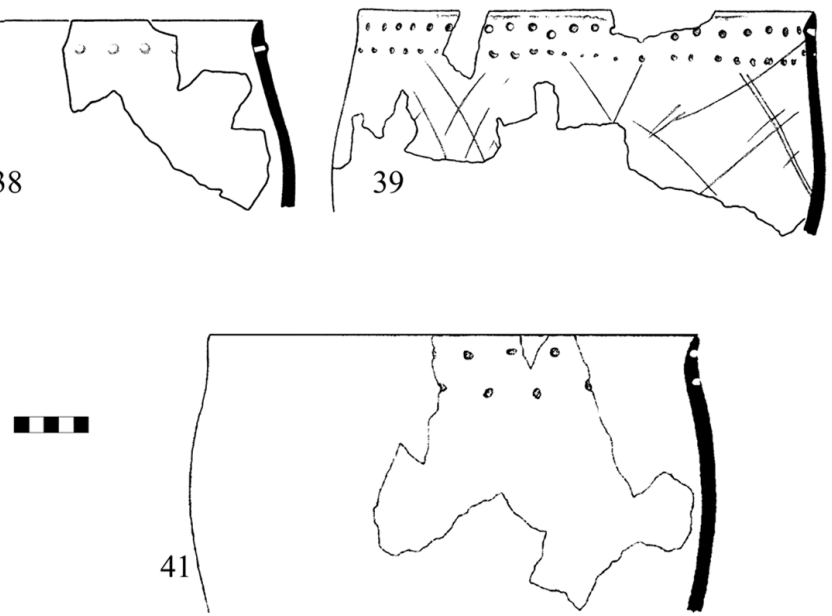

$\mathbf{1} 10,5$

Tab. 14. Elshanskaya culture pottery from the Middle Volga. 1-7 Ivanovskaya; 8-13 Chekalino IV; 1624, 35-36, 37-39, 41 Nizhnjaya Orljanka II; 25-30 Staroelshanskaya II; 31-34 Ozimenki 2; 40 Maksimovskaya (1, 3 after Vybornov 2008.Fig. 46; 2, 4, 7 after Vybornov 2008.Fig. 47; 5 after Morgunova 1995. Fig. 5; 6 after Morgunova 1995.Fig. 4; 8, 11-15 after Vybornov 2008.Fig. 49; 9 after Vybornov et al. 2000. Fig. 2; 10 after Vybornov et al. 2000.Fig. 7; 16-18, 20-23 after Vybornov 2008.Fig. 52; 19 after Vybornov 2008.Fig. 53; 24 after Morgunova 1995.Fig. 25; 25-30 after Vybornov 2008.Fig. 45; 31-32, 34 after Vybornov et al. 2000.Fig. 33; 33 after Vybornov 2008.Fig. 168; 37 -38 after Vybornov 2008.Fig. 53; 39 after Vybornov et al. 2000.Fig. 4; 41 after Vybornov et al. 2000.Fig. 5; 40 after Morgunova 1995.Fig. 13). 


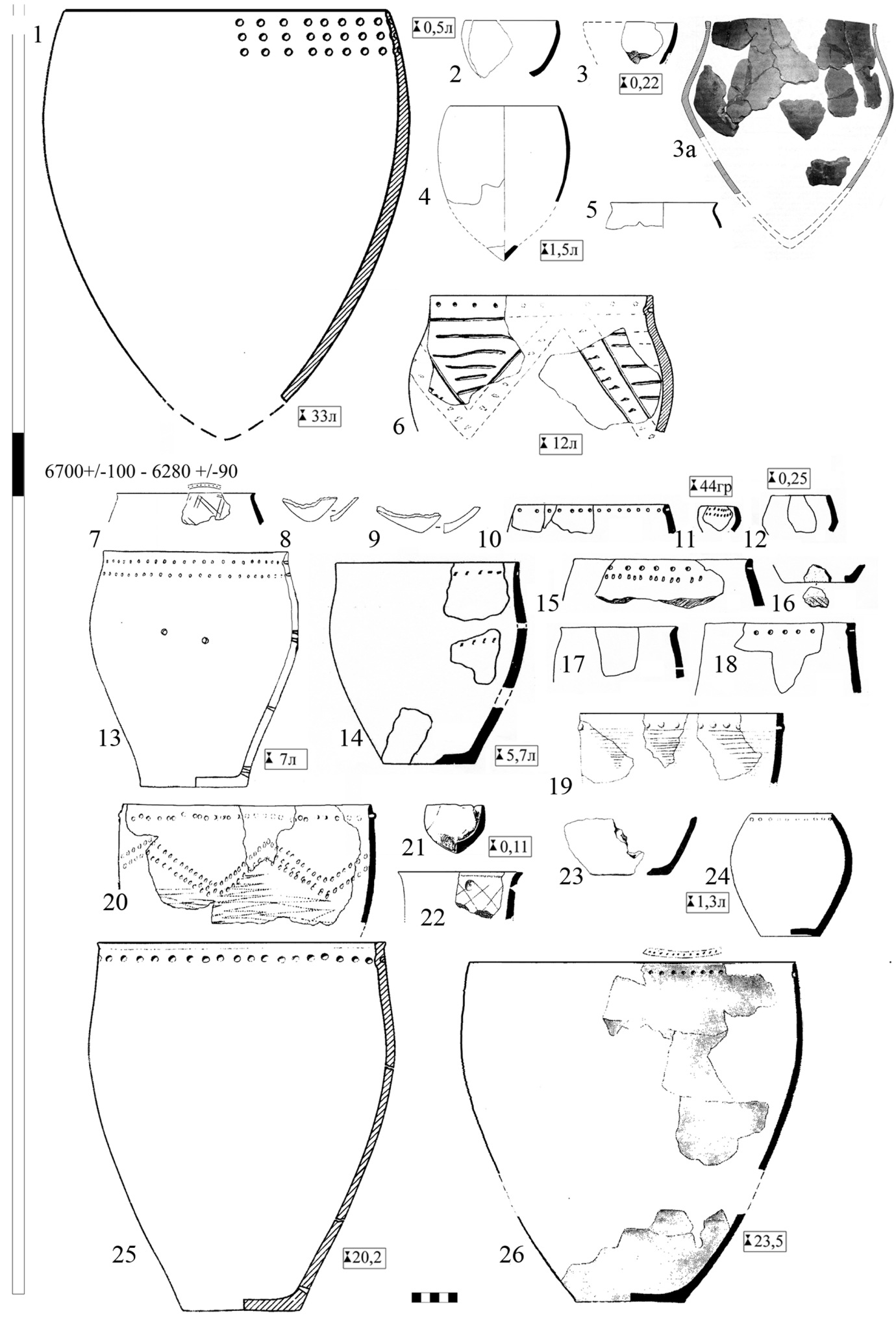

Tab. 15. Elshanskaya culture pottery of the Middle Volga. 1, 23-24 Iljinka; 2-5 Imerka 8; 3a Viunovo lake I; 6, 19, 25 Bol'shaya Rakovka II; 7-9, 13 Krasny gorodok; 10-12, 14-18 Lugovoe III; 20 Lebjazhinka I; 21-22, 26 Lebjazhinka IV (1 after Vybornov et al. 2000.Fig. 3; 2-3 after Arheologiya Mordovskogo kraya 2008.Fig. 32; 3a after Berezina et al. 2013.Fig. 4, 5; 4-5 after Vybornov 2008.Fig. 181; 7 after Vybornov et al. 2000.Fig. 6; 8-9,13 after Vybornov 2008.Fig. 59; 10-12, $14-18$ after Vybornov et al. 2012.Fig.10; 19 after Vybornov et al. 2000.Fig. 5; 20 after Vybornov et al. 2000.Fig. 11; 21 after Vybornov et al. 2000.Fig. 3; 22 after Vybornov et al. 2000.Fig. 4; 23 after Vybornov 2008.Fig. 62; 23 after Vybornov et al. 2000.Fig. 3; 25 after Vybornov et al. 2000.Fig. 18; 26 after Vybornov et al. 2000.Fig. 2). 

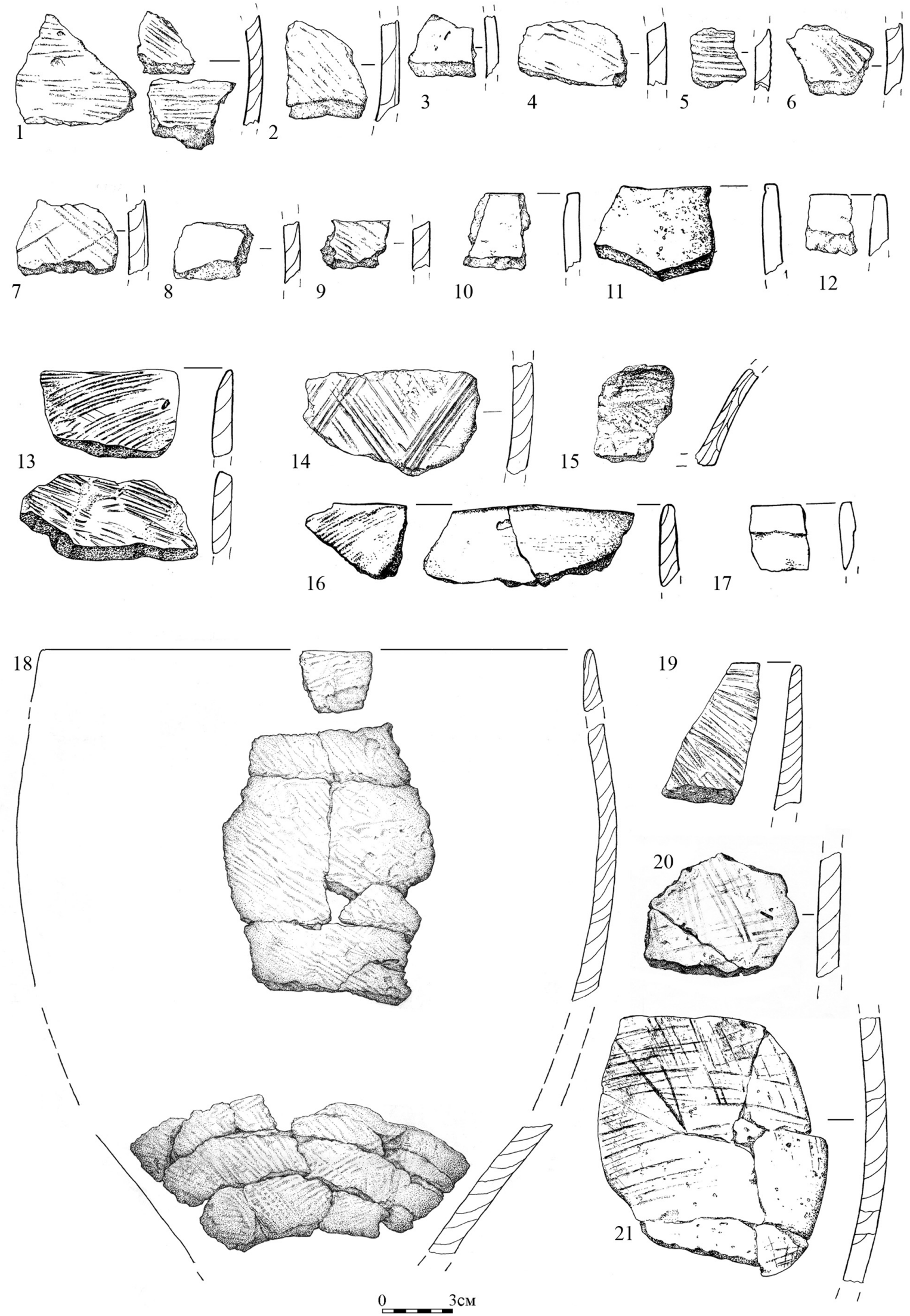

Tab. 16. Early Neolithic pottery of phase 'a-1' in the Dnepr-Dvina region. 

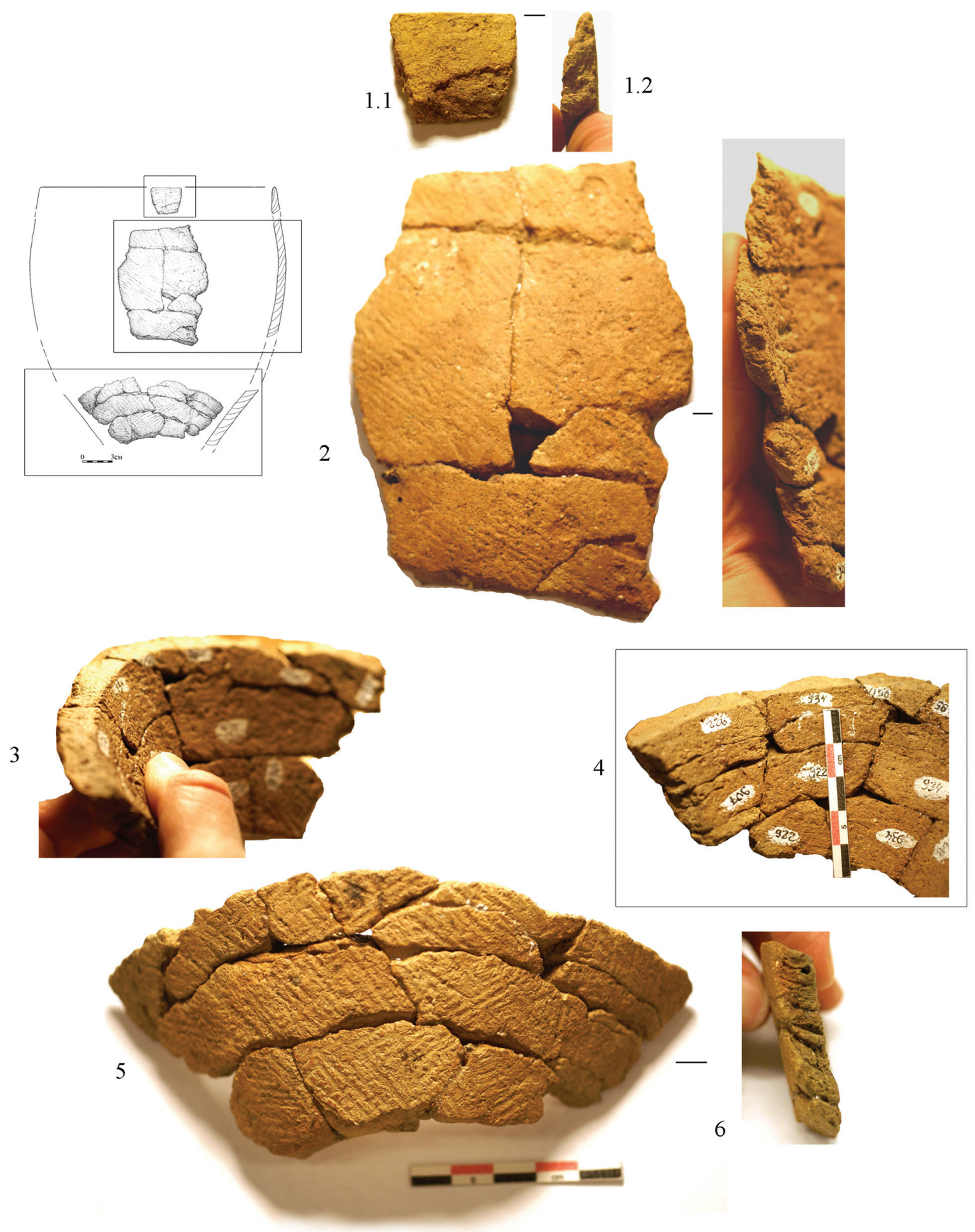

Tab. 17. Macro-traces on a vessel of phase 'a-1' in Dnepr-Dvina region: 1.1, 3, 4 fractures where coils join; 1.2, 3, 6 horizontal / slightly oblique porous structure and fractures, marking coil junctions; 2, 4, 5 horizontal fractures at coil junctions. 

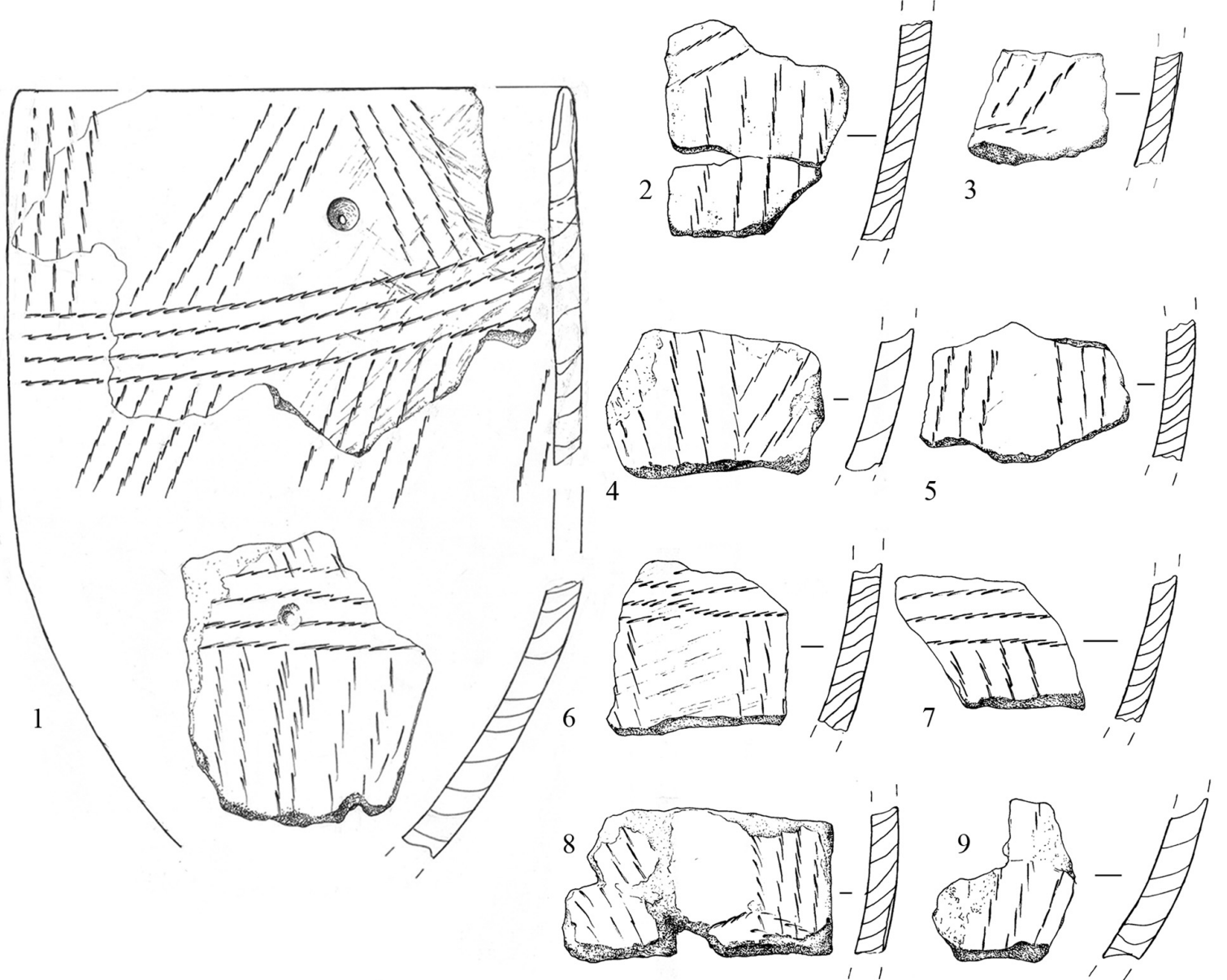

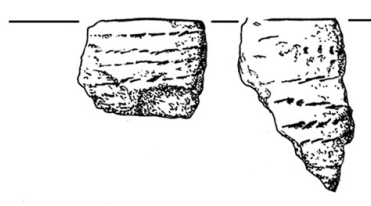

10
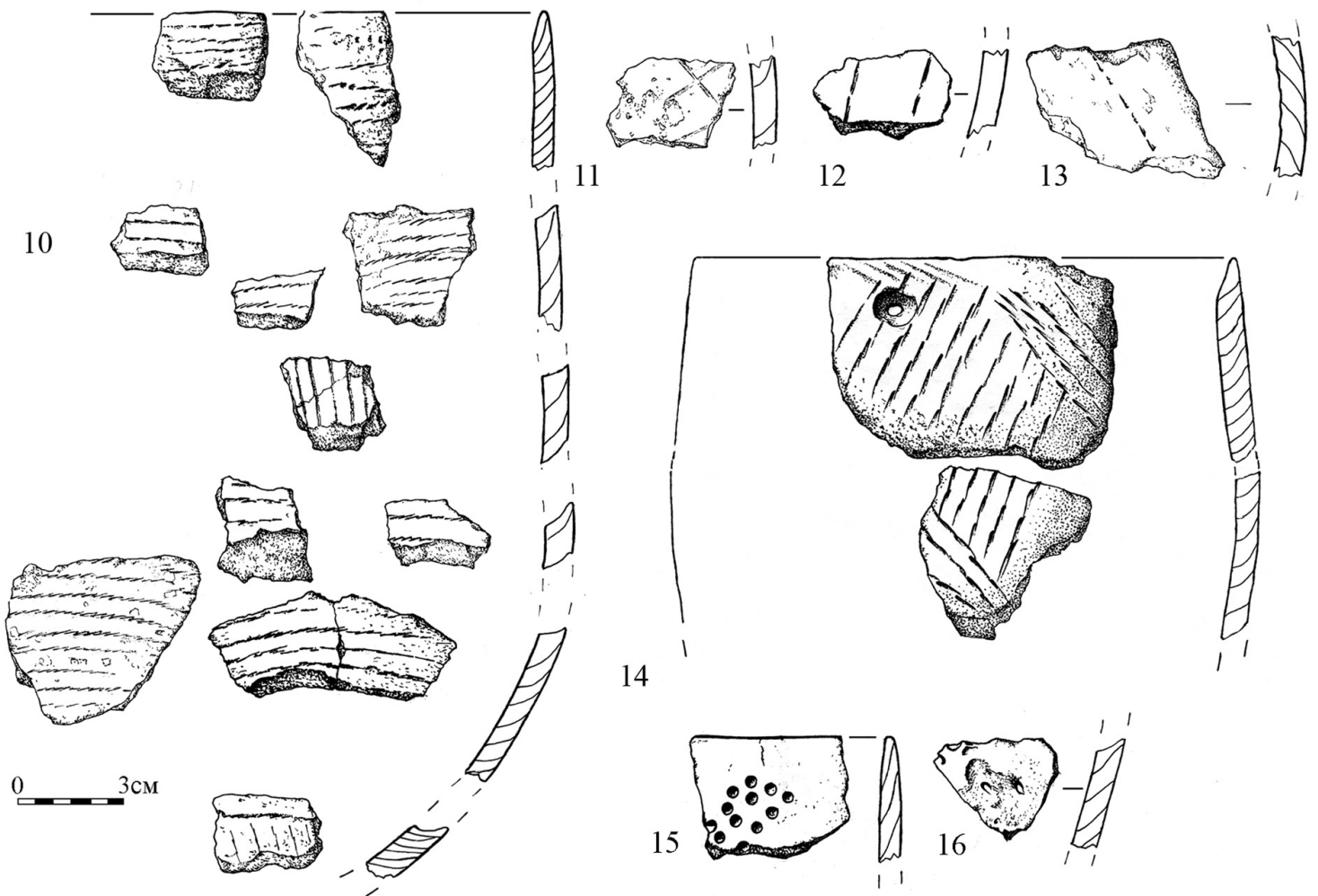

14

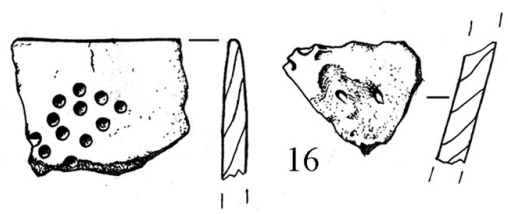

Tab. 18. Early Neolithic pottery of phase 'a' in the Dnepr-Dvina region. 

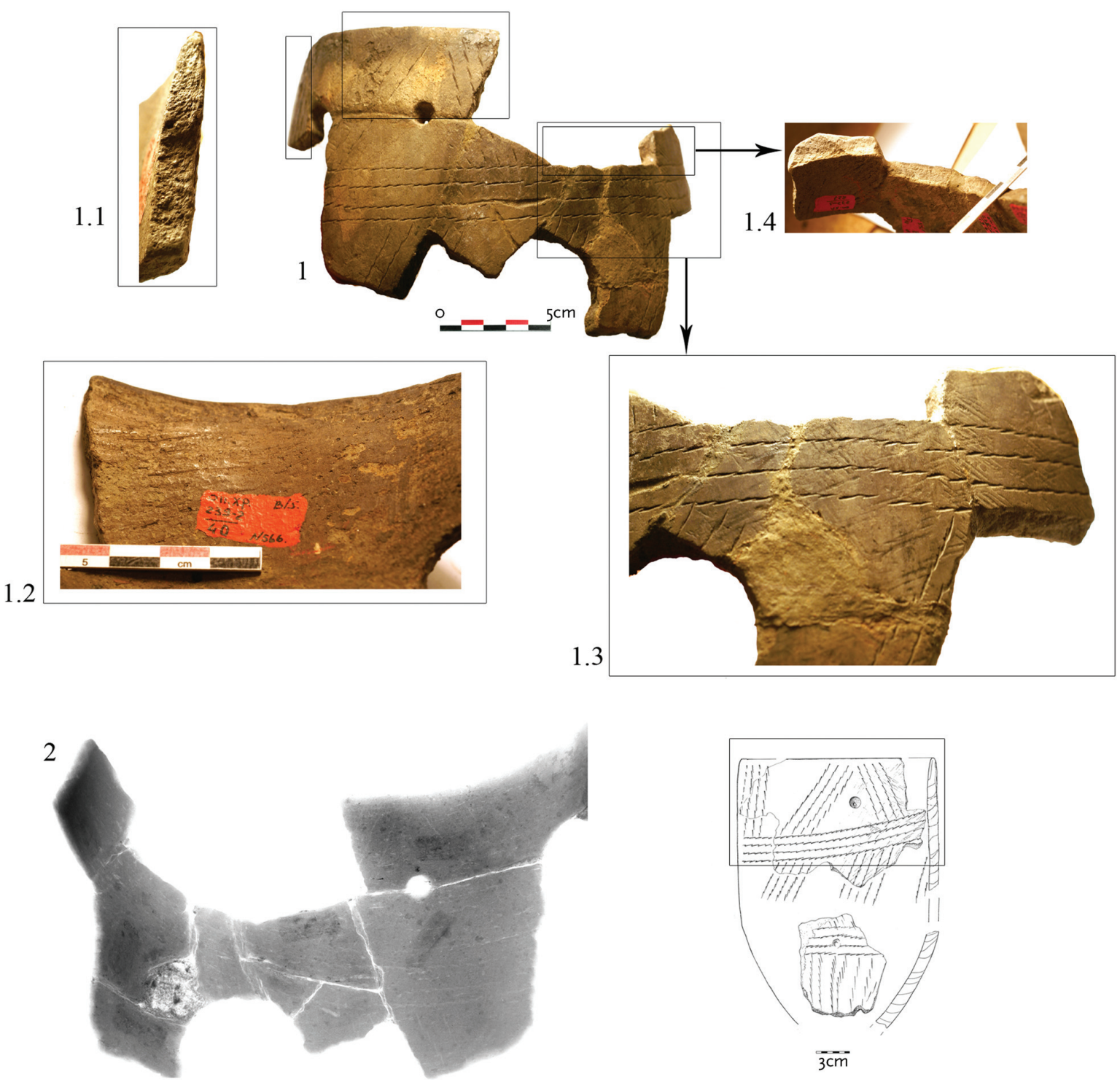

Tab. 19. Macro-traces (1) and radiograph (2) of the vessel of phase ' $a$ ' in the Dnepr-Dvina region. 1.1, 1.4 horizontal / slightly oblique porous structure and fractures, marking coil junction; 1.2 traces of surface roughening left by a comb-like tool; 1.3 traces of surface roughening left by a comb-like tool and further polishing of the surface. 


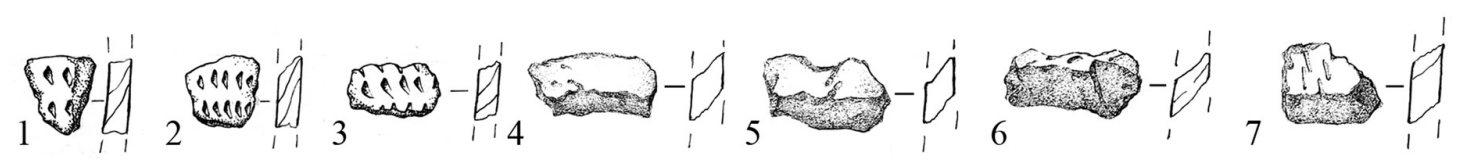

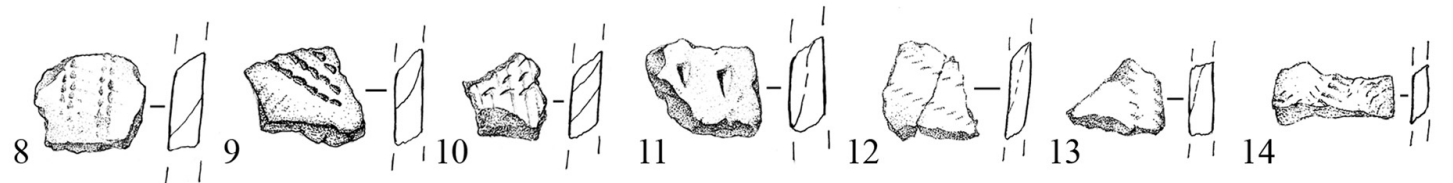
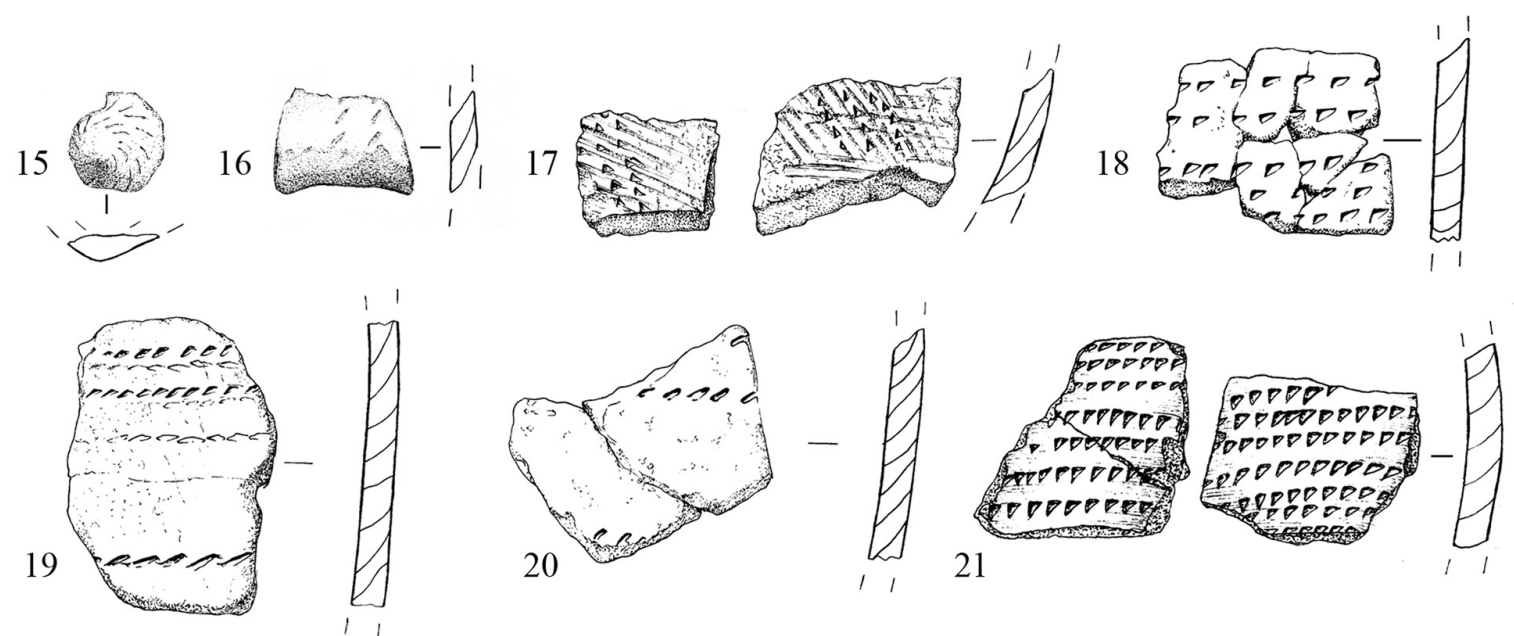

22
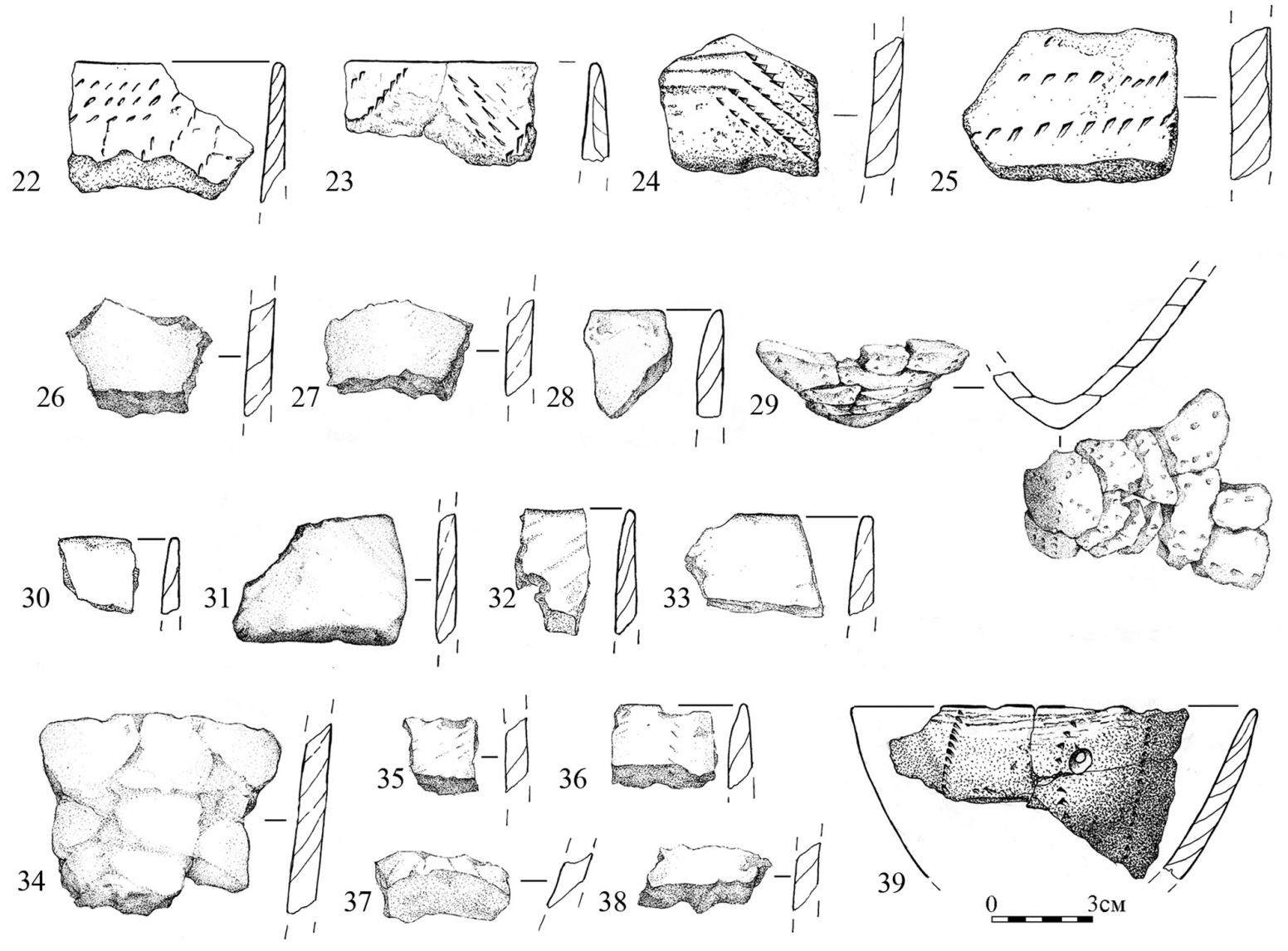

Tab. 20. Early Neolithic pottery of phase 'b' in the Dnepr-Dvina region. 